Europe PMC Funders Group

Author Manuscript

Cochrane Database Syst Rev. Author manuscript; available in PMC 2014 April 08.

Published in final edited form as:

Cochrane Database Syst Rev. ; 5: CD003519. doi:10.1002/14651858.CD003519.pub3.

\title{
Early skin-to-skin contact for mothers and their healthy newborn infants
}

\author{
Elizabeth R Moore ${ }^{1}$, Gene C Anderson², Nils Bergman ${ }^{3}$, and Therese Dowswell ${ }^{4}$ \\ ${ }^{1}$ School of Nursing, Vanderbilt University, Nashville, Tennessee, USA. \\ ${ }^{2}$ Case Western Reserve University, Professor Emerita, University of Florida, Gainesville, FL, \\ USA. \\ ${ }^{3}$ School of Child and Adolescent Health, and Department of Human Biology, University of Cape \\ Town, Cape Town, South Africa. \\ ${ }^{4}$ Cochrane Pregnancy and Childbirth Group, Department of Women's and Children's Health, The \\ University of Liverpool, Liverpool, UK
}

\begin{abstract}
Background-Mother-infant separation postbirth is common in Western culture. Early skin-toskin contact (SSC) begins ideally at birth and involves placing the naked baby, head covered with a dry cap and a warm blanket across the back, prone on the mother's bare chest. According to mammalian neuroscience, the intimate contact inherent in this place (habitat) evokes neurobehaviors ensuring fulfillment of basic biological needs. This time may represent a psychophysiologically 'sensitive period' for programming future physiology and behavior.
\end{abstract}

Objectives-To assess the effects of early SSC on breastfeeding, physiological adaptation, and behavior in healthy mother-newborn dyads.

Search methods-We searched the Cochrane Pregnancy and Childbirth Group's Trials Register (30 November 2011), made personal contact with trialists, and consulted the bibliography on kangaroo mother care (KMC) maintained by Dr. Susan Ludington.

Selection criteria-Randomized controlled trials comparing early SSC with usual hospital care.

Data collection and analysis-We independently assessed trial quality and extracted data.

Study authors were contacted for additional information.

Copyright $\odot 2012$ The Cochrane Collaboration. Published by John Wiley \& Sons, Ltd.

Contact address: Elizabeth R Moore, School of Nursing, Vanderbilt University, 314 Godchaux Hall, 21st Avenue South, Nashville,

Tennessee, 37240-0008, USA. elizabeth.moore@vanderbilt.edu.

CONTRIBUTIONS OF AUTHORS: For this update, Dr Elizabeth Moore wrote the first draft of the review and revised subsequent drafts in response to extensive feedback. Dr Gene Anderson and Dr Nils Bergman commented on the first draft of the updated review and contributed to the writing of the final draft. Therese Dowswell contributed to study assessment, analysis and drafting text.

Editorial group: Cochrane Pregnancy and Childbirth Group.

Publication status and date: New search for studies and content updated (no change to conclusions), published in Issue 5, 2012.

Review content assessed as up-to-date: 15 March 2012.

DECLARATIONS OF INTEREST: Three of the review authors have been active trialists in this area and have personal contact with many groups in this field, including the International Network for Kangaroo Mother Care based in Trieste, Italy; Bogota, Colombia; and Cleveland, Ohio. Dr Bergman has received reimbursement for lectures that he has conducted on Kangaroo Mother Care and from the sale of KMC related products.

DIFFERENCES BETWEEN PROTOCOL AND REVIEW: The protocol has been updated. We have modified outcomes and used updated methods. Quasi- randomized controlled trials are no longer part of the inclusion criteria so Anisfeld 1983 has now been excluded. 
Main results-Thirty-four randomized controlled trials were included involving 2177 participants (mother-infant dyads). Data from more than two trials were available for only eight outcome measures. For primary outcomes, we found a statistically significant positive effect of early SSC on breastfeeding at one to four months postbirth (13 trials; 702 participants) (risk ratio (RR) $1.27,95 \%$ confidence interval (CI) 1.06 to 1.53 , and SSC increased breastfeeding duration (seven trials; 324 participants) (mean difference (MD) 42.55 days, $95 \%$ CI -1.69 to 86.79 ) but the results did not quite reach statistical significance $(\mathrm{P}=0.06)$. Late preterm infants had better cardio-respiratory stability with early SSC (one trial; 31 participants) (MD 2.88, 95\% CI 0.53 to 5.23). Blood glucose 75 to 90 minutes following the birth was significantly higher in SSC infants (two trials, 94 infants) (MD $10.56 \mathrm{mg} / \mathrm{dL}, 95 \%$ CI 8.40 to 12.72).

The overall methodological quality of trials was mixed, and there was high heterogeneity for some outcomes.

Authors' conclusions-Limitations included methodological quality, variations in intervention implementation, and outcomes. The intervention appears to benefit breastfeeding outcomes, and cardio-respiratory stability and decrease infant crying, and has no apparent short- or long-term negative effects. Further investigation is recommended. To facilitate meta-analysis, future research should be done using outcome measures consistent with those in the studies included here. Published reports should clearly indicate if the intervention was SSC with time of initiation and duration and include means, standard deviations and exact probability values.

\section{Medical Subject Headings (MeSH)}

*Breast Feeding; *Object Attachment; *Skin Physiological Processes; Infant, Newborn; Kangaroo-Mother Care Method [*methods]; Mother-Child Relations; Mothers; Randomized Controlled Trials as Topic; Touch [*physiology]

\section{MeSH check words}

Female; Humans; Infant

\section{BACKGROUND}

\section{Description of the condition}

In humans, routine mother-infant separation shortly after birth is unique to the 20th century. This practice diverges from evolutionary history, where neonatal survival depended on close and virtually continuous maternal contact. Although from an evolutionary perspective skinto-skin contact (SSC) is the norm, separating the newborn from its mother soon after birth has now become common practice in many industrialized societies. Therefore, for the purpose of this review, SSC has to be the experimental intervention. Ironically, and importantly, the experimental intervention in studies with all other mammals is to separate newborns from their mothers.

\section{Description of the intervention}

Early SSC is the placing of the naked baby prone on the mother's bare chest at birth or soon afterwards. In the evolutionary context, this would have been "immediate and continuous". In the current care context, initiation and duration are not defined. The concept of "care" does not change; only the place where such care is provided changes. Further, although a dose-response effect has not been documented in randomized controlled trials (RCTs), the general belief is that SSC should continue until the end of the first successful breastfeeding to show an effect and to enhance early infant self-regulation (Widstrom 2011). 


\section{How the intervention might work}

The rationale for SSC comes from animal studies in which some of the innate behaviors of neonates that are necessary for survival are shown to be habitat dependent (Alberts 1994). In mammalian biology, maintenance of the maternal milieu following birth is required to elicit innate behaviors from the neonate and the mother that lead to successful breastfeeding, and thus survival. Separation from this milieu results in immediate distress cries (Alberts 1994) and "protest-despair" behavior. Human infants placed in a cot cry 10 times more than SSC infants. Their cry is similar to the vocalizations of separated rat pups (Michelsson 1996). In rodent studies, the pups who had the least attentive contact from their mothers were the ones whose health and intelligence were compromised across the lifespan (Francis 1999; Liu 1997; Liu 2000; Meaney 2005; Plotsky 2005). Also in the report by Liu 2000 a crossfostering study provided evidence for a direct relationship between maternal behavior and hippocampal development in the offspring.

Healthy, full term infants employ a species-specific set of innate behaviors immediately following delivery when placed in SSC with the mother (Righard 1990; Varendi 1994; Varendi 1998; Widstrom 1987; Widstrom 1990). They localize the nipple by smell and have a heightened response to odor cues in the first few hours after birth (Porter 1999; Varendi 1994; Varendi 1997). More recently Widstrom 2011 described the sequence of nine innate behaviors as the birth cry, relaxation, awakening and opening the eyes, activity (looking at the mother and breast, rooting, hand to mouth movements, soliciting sounds), a second resting phase, crawling towards the nipple, touching and licking the nipple, suckling at the breast and finally falling asleep. This 'sensitive period' predisposes or primes mothers and infants to develop a synchronous reciprocal interaction pattern, provided they are together and in intimate contact. Infants who are allowed uninterrupted SSC immediately after birth and who self-attach to the mother's nipple may continue to nurse more effectively. Effective nursing increases milk production and infant weight gain (De Carvalho 1983; Dewey 2003). Anderson 2004a used SSC as an intervention for 48 healthy mother/full term infant dyads with breastfeeding problems identified between 12 to 24 hours postbirth. SSC was provided during the next three consecutive breastfeedings. Breastfeeding was successful, even in this racially disparate sample (Chiu 2008) and was exclusive in $81 \%$ of these dyads at hospital discharge, $73 \%$ at one week, and $52 \%$ at one month postbirth. Temperatures were taken before (baseline), during, and after each SSC breastfeeding. Baseline temperatures reached, and remained in thermoneutral range (Chiu 2005) suggesting that mothers have the ability to modulate infant temperature if given the opportunity to breastfeed in SSC. Because these mothers and their infants were having breastfeeding difficulties, hospital staff and parents can logically be reassured that healthy newborn infants, with or without breastfeeding difficulties, may safely breastfeed in SSC so far as temperature is concerned. In a study of infrared thermography of the whole body during the first hour postbirth, Christidis 2003 found that SSC was as effective as radiant warmers in preventing heat loss in healthy full term infants.

SSC through sensory stimuli such as touch, warmth, and odor is a powerful vagal stimulant, which among other effects releases maternal oxytocin (Uvnas-Moberg 1998; Winberg 2005). Oxytocin causes the skin temperature of the mother's breast to rise, providing warmth to the infant (Uvnas-Moberg 1996). When operating in a safe environment, oxytocin, and direct SSC stimulation of vagal efferents, are probably part of a broader neuro-endocrine milieu (Porges 2007). A global physiological regulation of the autonomic nervous system is achieved, supporting growth and development, (homeorhesis). Under conditions perceived by the newborn to be dangerous, stress mechanisms come into operation, with the focus on survival rather than development (allostasis). The theory of allostasis is the relationship between psycho-neurohormonal responses to stress and physical and psychological manifestations of health and illness (McEwen 1998; Shannon 2007). 
Allostasis is necessary, and it can be viewed as beneficial, because its goal is to bring aberrant physiology closer to normal; however, an allostatic response comes with a physiological cost referred to as allostatic load. The higher the allostatic load the greater the damage from stress, because allostatic load is cumulative. SSC also lowers maternal stress levels. Handlin 2009 found a dose-response relationship between the amount of SSC and maternal plasma cortisol two days postbirth. A longer duration of SSC was correlated with a lower median level of cortisol $(r=-0.264, \mathrm{P}=0.044)$.

Oxytocin antagonizes the flight-fight effect, decreasing maternal anxiety and increasing calmness and social responsiveness (Uvnas-Moberg 2005). During the early hours after birth, oxytocin may also enhance parenting behaviors (Uvnas-Moberg 1998; Winberg 2005). SSC outcomes for mothers suggest improved bonding/attachment (Affonso 1989); other outcomes are increased sense of mastery and self-enhancement, resulting in increased confidence. Sense of mastery and confidence are relevant outcomes because they predict breastfeeding duration (Dennis 1999). Women with low breastfeeding confidence have three times the risk of early weaning (O'Campo 1992) and low confidence is also associated with perceived insufficient milk supply (Hill 1996).

Marin 2010 found that time to expulsion of the placenta was shorter $(M=409 \pm 245 \mathrm{sec}$. $)$ in mothers of SSC infants than in control mothers $(M=475 \pm 277$ sec., $P=0.05)$. When SSC on the mother's abdomen, the infant's knees and legs press into her abdomen in a massaging manner which would logically induce uterine contractions and thereby reduce risk of postpartum hemorrhage. Mothers who experience SSC have reduced bleeding (Dordevic 2008) and more rapid delivery of the placenta (Marin 2010).

In previous meta-analyses with full term infants, early contact was associated with continued breastfeeding (Bernard-Bonnin 1989; Inch 1989; Perez-Escamilla 1994). Just altering hospital routines can increase breastfeeding levels in the developed world (Rogers 1997). Conde-Agudelo 2011 conducted a Cochrane review of 16 randomized clinical trials of kangaroo mother care (KMC), a strategy of continuous or intermittent SSC with exclusive or nearly exclusive breastfeeding and early hospital discharge of infants less than $2500 \mathrm{~g}$ at birth in settings with limited resources. KMC was associated with reductions in several clinically important adverse infant outcomes, including mortality at hospital discharge and at latest follow-up, nosocomial infection/sepsis at hospital discharge and severe infection/ sepsis at latest follow-up, hypothermia and hospital length of stay. SSC mothers were more satisfied with the method of care, and more likely to be exclusively breastfeeding at hospital discharge. In another meta-analysis of 24 studies (13 case-series, five RCT's, one cross-over and four cohort), Mori 2010 evaluated outcomes in both low and normal birthweight infants up to 28 days old. Infant body temperature increased $0.22{ }^{\circ} \mathrm{C}$ during and $0.14{ }^{\circ} \mathrm{C}$ after SSC ( $\mathrm{P}<0.001,21$ studies); heart rate increased 2.04 beats per minute $(\mathrm{bpm})$ during $(\mathrm{P}=0.05)$ and decreased $0.07 \mathrm{bpm}$ after SSC $(\mathrm{P}=0.95,12$ studies $)$; oxygen saturation decreased $0.60 \%$ (three/fifths of $1 \%$ ) during $(\mathrm{P}=0.01)$ and $0.48 \%$ (essentially one-half of $1 \%$ ) after SSC ( $\mathrm{P}=0.06,10$ studies). These decreases in oxygen saturation are too small to be of clinical significance.

\section{Why it is important to do this review}

Separation of mothers from their newborn infants at birth has become standard practice, despite mounting evidence that this may have harmful effects. However, delivery room and postpartum hospital routines may significantly disrupt early maternal-infant interactions including breastfeeding (Anderson 2004a; Odent 2001; Winberg 1995). The possibility exists that postnatal separation of human infants from their mothers is stressful (Anderson 1995) and might result in harmful effects that persist across the lifespan, if the studies with laboratory animals cited earlier hold true for humans. This possibility needs careful 
evaluation using the allostatic theoretical framework (McEwen 1998) as well as new epigenetic findings (Meaney 2005).

A concurrent widespread decline in breastfeeding is of major public health concern. Although more women are initiating breastfeeding, fewer are breastfeeding exclusively. Using data from the Infant Feeding Practices Study II conducted in the United States by the Food and Drug Administration in 2005 to 2007, Grummer-Strawn 2008 found that 83\% of mothers initiated breastfeeding, but only $48 \%$ exclusively breastfed during their hospital stay. These innate behaviors can be disrupted by early post-partum hospital routines as shown experimentally by Widstrom 1990 and in descriptive studies by Gomez 1998; Jansson 1995 and Righard 1990. Gomez 1998 found that infants were eight times more likely to breastfeed spontaneously if they spent more than 50 minutes in SSC with their mothers immediately after birth, and concluded that the dose of SSC might be an essential component regarding breastfeeding success. Bramson 2010 showed a clear dose-response relationship between SSC in the first three hours postbirth and exclusive breastfeeding at discharge in a large $(\mathrm{N}=21,842$ mothers) hospital-based cohort study, (odds ratio $(\mathrm{OR})$ for exclusive breastfeeding $=1.665$ if in SSC for 16 to 30 minutes, and OR $=3.145$ for more than 60 minutes of SSC).

The purpose of this review is to examine the available evidence of the effects of early SSC on breastfeeding exclusivity and duration and other outcomes in mothers and their healthy full term and late preterm newborn infants. Although our intent is to examine all clinically important outcomes, breastfeeding is the predominant outcome investigated so far in healthy newborns. Hence, our emphasis is on breastfeeding, although we also will examine maternal-infant physiology and behavior. Because the focus of this review is on mothers and their healthy infants, potential effects of early SSC on father-infant attachment and also the resistance of staff to this intervention are beyond the scope of this review. Maternal feelings about early SSC and satisfaction with the birth experience are important and relevant but require more qualitative methods. The focus of this review is on randomized controlled trials used to test the effects of early SSC. This is an update of a Cochrane review first published in 2003 and previously updated in 2007.

\section{OBJECTIVES}

To assess the effects of early skin-to-skin contact for healthy newborn infants compared to standard contact (infants held swaddled or dressed in their mothers arms, placed in open cribs or under radiant warmers).

The three main outcome categories include:
a. establishment and maintenance of breastfeeding/lactation;
b. infant physiology - thermoregulation, respiratory, cardiac, metabolic function, neurobehavior;
c. maternal-infant bonding/attachment.

\section{METHODS}

\section{Criteria for considering studies for this review}

Types of studies-All randomized controlled trials in which the active encouragement of early skin-to-skin contact (SSC) between mothers and their healthy newborn infants was compared to usual hospital care. We have not included quasi-randomized trials (e.g. where assignment to groups was alternate or by day of the week, or by other non-random methods). 
Types of participants-Mothers and their healthy full term or late preterm newborn infants (34 to less than 37 completed weeks' gestation) having early SSC starting less than 24 hours after birth, and controls undergoing standard patterns of care.

Types of interventions-Early SSC for term or late preterm infants can be divided into several subcategories.

a. In 'birth SSC', the infant is placed prone skin-to-skin on the mother's abdomen or chest during the first minute postbirth. The infant is suctioned while on the mother's abdomen or chest, if medically indicated, thoroughly dried and covered across the back with a prewarmed blanket. To prevent heat loss, the infant's head may be covered with a dry cap that is replaced when it becomes damp. Ideally, all other interventions are delayed until at least the end of the first hour postbirth or the first successful breastfeeding.

b. In 'very early SSC', beginning approximately 30 to 40 minutes postbirth, the naked infant, with or without a cap, is placed prone on the mother's bare chest. A blanket is placed across the infant's back.

c. 'Early SSC' can begin anytime between one and 24 hours postbirth. The baby is naked (with or without a diaper and cap) and is placed prone on the mother's bare chest between the breasts. The mother may wear a blouse or shirt that opens in front, or a hospital gown worn backwards, and the baby is placed inside the gown so that only the head is exposed. What the mother wears and how the baby is kept warm and what is placed across the baby's back may vary. What is most important is that the mother and baby are in direct ventral-to-ventral SSC and the infant is kept dry and warm.

In the future these groups may be analyzed separately. However, at present, not enough studies are available for subgroup analysis. Standard contact includes a number of diverse conditions, infants held swaddled or dressed in their mothers arms, or infants placed in open cribs or under radiant warmers in the mother's room or elsewhere with no holding allowed.

\section{Types of outcome measures}

\section{Primary outcomes}

\section{Breastfeeding outcomes:}

1. Number of mothers breastfeeding (any breastfeeding) one month to four months postbirth

2. Duration of breastfeeding

\section{Infant outcomes:}

1. Infant stabilization during the transition to extra-uterine life Measured by the SCRIP score (e.g. stability of the cardio-respiratory system - a composite score of heart rate, respiratory status and arterial hemoglobin oxygen saturation $(\mathrm{SaO} 2)$, range of scores $=0-6$ (Fischer 1998)

2. Blood glucose levels during/after SSC compared to standard care

3. Infant thermoregulation = temperature changes during/ after SSC compared to standard care (measured by axillary temperature)

\section{Secondary outcomes}

\section{Breastfeeding outcomes (secondary):}


1. Effective breastfeeding (Infant Breastfeeding Assessment Tool (IBFAT) (Matthews 1988; Matthews 1991)

2. Breastfeeding rates/exclusivity (using either the Labbok 1990 Index of Breastfeeding Status or the Thulier 2010 five-point scale) at hospital discharge up to two weeks postbirth

3. Breastfeeding rates/exclusivity (using either the Labbok 1990 Index of Breastfeeding Status or the Thulier 2010 five-point scale) three to six months postbirth

4. Maternal breast temperature during and after SSC

5. Breast engorgement

\section{Infant outcomes (secondary):}

1. Infant heart rate during/after SSC compared to standard care

2. Respiratory status - respiratory rate during/after SSC compared to standard care

3. Neonatal intensive care unit admissions

4. Infant weight changes/rate of growth in $\mathrm{gm} / \mathrm{kg} /$ day (daily weight change, change in weight over days of study) (Hill 2007)

5. Length of hospital stay

6. Duration of infant crying

\section{Maternal outcomes:}

1. Maternal perceptions of bonding/connection to her infant

2. Maternal pain post cesarean

3. Maternal sensitivity to her infant's cues

4. Maternal anxiety

5. Maternal parenting confidence

\section{Search methods for identification of studies}

Electronic searches-We searched the Cochrane Pregnancy and Childbirth Group's Trials Register by contacting the Trials Search Co-ordinator (30 November 2011).

The Cochrane Pregnancy and Childbirth Group's Trials Register is maintained by the Trials Search Co-ordinator and contains trials identified from:

1. quarterly searches of the Cochrane Central Register of Controlled Trials (CENTRAL);

2. weekly searches of MEDLINE;

3. weekly searches of EMBASE;

4. handsearches of 30 journals and the proceedings of major conferences;

5. weekly current awareness alerts for a further 44 journals plus monthly BioMed Central email alerts.

Details of the search strategies for CENTRAL, MEDLINE and EMBASE, the list of handsearched journals and conference proceedings, and the list of journals reviewed via the 
current awareness service can be found in the 'Specialized Register' section within the editorial information about the Cochrane Pregnancy and Childbirth Group.

Trials identified through the searching activities described above are each assigned to a review topic (or topics). The Trials Search Co-ordinator searches the register for each review using the topic list rather than keywords.

Searching other resources-The first three review authors have been active trialists in this area and have personal contact with many groups in this field including the International Network for Kangaroo Mother Care, based in Trieste (see Appendix 1).

We did not apply any language restrictions.

\section{Data collection and analysis}

For the methods used when assessing the trials identified in the previous version of this review, see Appendix 2.

For this update we used the following methods when assessing the reports identified by the updated search.

Selection of studies-Two review authors independently assessed for inclusion all the potential studies we identified as a result of the search strategy. First, we screened titles and abstracts of all the retrieved studies. Two review authors independently assessed full text articles for inclusion in the review. We resolved any disagreement through discussion or, if required, we consulted a third individual. We have listed studies that did not meet the inclusion criteria for the review in the Characteristics of excluded studies tables along with the reasons for their exclusion.

Data extraction and management-We designed a form to extract data. For eligible studies, at least two review authors extracted the data using the agreed form. We resolved discrepancies through discussion or, if required, we consulted a third person. We entered data into Review Manager software (RevMan 2011) and checked for accuracy.

When information regarding any of the above was unclear, we attempted to contact authors of the original reports to provide further details.

Assessment of risk of bias in included studies-Two review authors independently assessed risk of bias for each study using the criteria outlined in the Cochrane Handbook for Systematic Reviews of Interventions (Higgins 2011). We resolved any disagreement by discussion or by involving a third assessor. We used the electronic 'Risk of bias' form in RevMan 2011 to describe study methodological quality.The following criteria were assessed.

(1) Sequence generation (checking for possible selection bias): We described for each included study the method used to generate the allocation sequence in sufficient detail to allow an assessment of whether it produced comparable groups.

We assessed the method as:

- $\quad$ low risk of bias (any truly random process, e.g. random number table; computer random number generator);

- high risk of bias (any non-random process, e.g. odd or even date of birth; hospital or clinic record number); 
- $\quad$ risk of bias unclear.

(2) Allocation concealment (checking for possible selection bias): We described for each included study the method used to conceal the allocation sequence and determined whether intervention allocation could have been foreseen in advance of, or during recruitment, or changed after assignment.

We assessed the methods as:

- low risk of bias (e.g. telephone or central randomization; consecutively numbered sealed opaque envelopes);

- high risk of bias (open random allocation; unsealed or non-opaque envelopes, alternation; date of birth);

- risk of bias unclear.

(3) Blinding (checking for possible performance and detection bias): We described for each included study the methods used, if any, to blind study participants and personnel from knowledge of which intervention a participant received. We considered that studies were at low risk of bias if they were blinded, or if we judged that the lack of blinding could not have affected the results. We assessed blinding separately for different outcomes or classes of outcomes. We assessed the methods as:

- low, high or unclear risk of bias for participants;

- low, high or unclear risk of bias for personnel;

- low, high or unclear risk of bias for outcome assessors.

(4) Incomplete outcome data (checking for possible attrition bias through withdrawals, dropouts, protocol deviations): We described for each included study, and for each outcome or class of outcomes, the completeness of data including attrition and exclusions from the analysis. We stated whether attrition and exclusions were reported, the numbers included in the analysis at each stage (compared with the total randomized participants), reasons for attrition or exclusion where reported, and whether missing data were balanced across groups or were related to outcomes. Where sufficient information was reported, or could be supplied by the trial authors, we re-included missing data in the analyses. We assessed methods as:

- low risk of bias where loss was low and was balanced across groups;

- high risk of bias where attrition was high or unbalanced across groups;

- unclear risk of bias.

(5) Selective reporting bias: We described for each included study how we investigated the possibility of selective outcome reporting bias and what we found. We assessed the methods as:

- low risk of bias (where it was clear that all of the study's prespecified outcomes and all expected outcomes of interest to the review had been reported);

- high risk of bias (where not all the study's prespecified outcomes had been reported; one or more reported primary outcomes were not prespecified; outcomes of interest were reported incompletely and so could not be used; study failed to include results of a key outcome that would have been expected to have been reported); 
- unclear risk of bias.

(6) Other sources of bias: We described for each included study any important concerns we had about other possible sources of bias.

We assessed whether each study was free of other problems that could put it at risk of bias:

- low, high or unclear risk of other bias.

(7) Overall risk of bias: We made explicit judgements about whether studies were at high risk of bias, according to the criteria given in the Cochrane Handbook for Systematic Reviews of Interventions (Higgins 2011). With reference to (1) to (6) above, we assessed the likely magnitude and direction of the bias and whether we considered it is likely to impact on the findings. We explored the impact of the level of bias through undertaking sensitivity analysis.

\section{Measures of treatment effect}

Dichotomous data: For dichotomous data, we have presented results as summary risk ratio with $95 \%$ confidence intervals.

Continuous data: For continuous data, we used the mean difference if outcomes were measured in the same way between trials. We used the standardized mean difference to combine trials that measured the same outcome, but used different methods.

Unit of analysis issues-The unit of analysis was the healthy newborn infant receiving SSC or standard care.

We did not identify any cluster-randomized trials in this version of the review. If we identify such trials in future updates we will include them in the review along with individually randomized trials.

To take account of design effect, provided sufficient information is available, we will adjust the sample sizes and event rates from cluster-randomized studies using the methods described in the Cochrane Handbook for Systematic Reviews of Interventions (Higgins 2011). We will use an estimate of the intracluster correlation coefficient (ICC) derived from the trial (if possible), or from another source. If ICCs from other sources are used, we will report this and will conduct sensitivity analyses to investigate the effect of variation in the ICC.

We will consider that it is reasonable to combine the results from both individually and cluster-randomized trials if there is little heterogeneity between the study designs and the interaction between the effect of intervention and the choice of randomization unit is considered to be unlikely.

Dealing with missing data-For included studies, we noted levels of attrition and have described in the Characteristics of included studies tables the levels of loss to follow up at each data collection point.

For all outcomes, we carried out analyses, as far as possible, on an intention-to-treat basis, i.e. we attempted to include all participants randomized to each group in the analyses, and all participants were analyzed in the group to which they were allocated, regardless of whether or not they received the allocated intervention. The denominator for each outcome 
in each trial was the number randomized minus any participants whose outcomes were known to be missing.

Assessment of heterogeneity-We assessed statistical heterogeneity in each metaanalysis using the $\mathrm{I}^{2}$ and $\mathrm{Chi}^{2}$ statistics. We regarded heterogeneity as substantial if either $\mathrm{I}^{2}$ was greater than $40 \%$ or there was a low $\mathrm{P}$ value (less than 0.10) in the $\mathrm{Chi}^{2}$ test for heterogeneity.

Assessment of reporting biases-If there were 10 or more studies in the meta-analysis we planned to investigate reporting biases (such as publication bias) using funnel plots. In this version of the review insufficient studies contributed data to allow us to carry out this analysis for all but one of the outcomes. In future updates, if more studies become available we will assess funnel plot asymmetry visually, and will use formal tests for funnel plot asymmetry. For continuous outcomes, we will use the test proposed by Egger 1997, and for dichotomous outcomes, we will use the test proposed by Harbord 2006. If asymmetry is detected in any of these tests or is suggested by a visual assessment, we will perform exploratory analyses to investigate it.

Data synthesis-We carried out statistical analysis using the Review Manager software (RevMan 2011). We used fixed-effect meta-analysis for combining data when it was reasonable to assume that studies were estimating the same underlying treatment effect: i.e. where trials were examining the same intervention, and the trials' populations and methods were judged sufficiently similar. If there was clinical heterogeneity sufficient to expect that the underlying treatment effects differed between trials, or if substantial statistical heterogeneity was detected, we used random-effects meta-analysis to produce an overall summary if an average treatment effect across trials was considered clinically meaningful. The random-effects summary was treated as the average range of possible treatment effects and we have discussed the clinical implications of treatment effects differing between trials. If the average treatment effect was not clinically meaningful, we did not combine trials.

If we used random-effects analyses, the results have been presented as the average treatment effect with its $95 \%$ confidence interval, along with estimates of $\mathrm{I}^{2}$.

Subgroup analysis and investigation of heterogeneity-For primary outcomes we planned subgroup analysis by:

1. gestational age at birth; infants born at term (greater than 37 weeks) versus later preterm (greater than 34 to 37 weeks);

2. type of SSC (at birth, very early SSC, and early SSC).

We planned to assess differences between subgroups by using the interaction tests available in RevMan 2011. In this version of the review insufficient studies contributed data to allow us to carry out the planned analysis. In future updates, as more data become available, we hope to be able to look for possible differences between subgroups.

Sensitivity analysis-We planned to carry out sensitivity analysis to look at whether the methodological quality of studies had an impact on results; however, none of the included studies met all criteria for low risk of bias and we therefore did not carry out this analysis in this version of the review. In view of the mixed methodological quality of trials we advise caution in the interpretation of results. For our two primary outcomes there were high levels of heterogeneity; much of the variation was due to a single study; we therefore carried out sensitivity analysis excluding this study from the analysis to examine the impact on results 
(Sosa 1976a). For infant physiological outcomes, we also carried out sensitivity analysis to explore high levels of heterogeneity.

\section{RESULTS}

\section{Description of studies}

See: Characteristics of included studies; Characteristics of excluded studies; Characteristics of ongoing studies.

\section{Results of the search}

Included studies: Thirty-four studies with 2177 mother-infant dyads met the inclusion criteria. None of the 34 studies met all of the methodological quality criteria (see Figure 1 and Figure 2). The total sample sizes in the studies ranged from eight to 204 mother-infant pairs. The studies represented very diverse populations in Canada, Chile, Germany, Guatemala, Iran, Israel, Italy, Japan, Nepal, Poland, Russia, South Africa, Spain, Sweden, Taiwan, Thailand, the United Kingdom, and the United States. All but four of the 34 studies included only healthy full term infants. Four studies (Anderson 2003; Bergman 2004; Chwo 1999; Syfrett 1996) were done with healthy late preterm infants who were assigned to the normal newborn nursery. Three studies (Gouchon 2010; McClellan 1980; Nolan 2009) were conducted with mothers scheduled for repeat cesarean birth using regional anesthesia. One study (Huang 2006) was conducted with hypothermic, but otherwise healthy, newborns postcesarean birth with spinal anesthesia. One paper reported results for studies carried out in three different sites and we have treated these as three different studies in the data and analysis (Sosa 1976a; Sosa 1976b; Sosa 1976c). A large number of outcomes (31) have been reported in the analysis, but only 15 included multiple trials and for many of the other outcomes only a relatively small number of studies (two or three) contributed data. Four of the 34 included studies did not report data on our prespecified primary and secondary outcomes and data from these studies have not been included in the analysis (Curry 1982; Fardig 1980; Ferber 2004; Hales 1977). Details of all included studies are set out in the Characteristics of included studies tables.

The characteristics of the intervention varied greatly between studies. Duration of skin-toskin (SSC) ranged from approximately 15 minutes (De Chateau 1977; Svejda 1980; Thomson 1979; Vaidya 2005) to a mean of 37 of 48 hours (84\%) of continuous SSC (Syfrett 1996); in this study all dyads received 24 minutes of SSC before randomization. HakeBrooks 2003 (under Anderson 2003) reported that SSC mothers gave SSC 22\% of the time and held their wrapped infants for $11.6 \%$ of the observation period. Although SSC began by 0 to 15 minutes postbirth in 18 of the 34 studies, the SSC dyads in the study by Shiau 1997 could not begin until four hours postbirth because of hospital policy. SSC did not begin until a mean of 21.3 hours postbirth in the study by Chwo 1999 of late preterm infants 34 to 36 weeks' gestational age. In 22 of the 34 studies the infants were given the opportunity to suckle during SSC but only five studies (Carfoot 2004; Carfoot 2005; Gouchon 2010; Khadivzadeh 2008; Moore 2005) documented the success of the first breastfeeding using a validated instrument, the Infant Breastfeeding Assessment Tool. The amount of assistance the mothers received with breastfeeding during SSC was unclear in many of the research reports.

Substantial differences were found between studies in the amount of separation that occurred in the control group. In eight studies (Chwo 1999; Hales 1977; Huang 2006; Mizuno 2004; Shiau 1997; Sosa 1976a; Sosa 1976b; Sosa 1976c), infants were removed from their mothers immediately postbirth and reunited 12 to 24 hours later. In five studies (Carlsson 1978; Craig 1982; Gouchon 2010; Svejda 1980; Thomson 1979), the mothers held 
their swaddled infants for about five minutes soon after birth and then were separated from their infants. Control mothers held their swaddled infants six times for 60 minutes in Chwo 1999, 20 minutes in Kastner 2005, 60 minutes in Moore 2005 and for two hours in the recovery room in Punthmatharith 2001. The swaddled control infants in Khadivzadeh 2008 were reunited with their mothers after the episiotomy repair. Control infants in Nolan 2009 were separated from their mothers for a mean of 21 minutes and in Gouchon 2010 for a mean of 51 minutes post-cesarean birth. There were four groups in the study by Bystrova 2003; an SSC group, a mother's arms group where the infants were held swaddled or dressed, a nursery group and a reunion group where the infants were taken to the nursery immediately postbirth for 120 minutes but reunited with their mothers for rooming-in on the postpartum unit. In Hake-Brooks 2003 (under Anderson 2003) control mothers held their wrapped infants $13.9 \%$ of the time ( $M=6.67$ hours).

Excluded studies: Fifty studies were assessed and excluded from the review. The primary reason for exclusion was that the investigators did not state that the infants in the intervention group received early SSC with their mothers. When the information in the research report was unclear, where possible we contacted the investigators, to determine whether the early contact was indeed skin-to-skin (see the table of Characteristics of excluded studies).

New studies found at this update: Five randomized controlled trials have been added to the review. Two of the new studies (Gouchon 2010; Nolan 2009) were conducted with mothers scheduled for repeat cesarean birth using regional anesthesia. One study (Huang 2006) was conducted with hypothermic, but otherwise healthy, newborns post-cesarean birth with spinal anesthesia. The results from four additional reports involving the data set from Bystrova 2003, two additional reports from Anderson 2003 and one additional report from Bergman 2004 have been added to this update.

\section{Risk of bias in included studies}

Allocation-The overall methodological quality of the included studies was mixed and many studies did not provide clear information on the way the that the randomization sequence was generated, or on the methods used to conceal group allocation at the point of randomization. In 18 of the 34 studies the way the randomization sequence was produced was not clearly described and in 22 of the 34 studies, not enough information was provided to determine if the method of random assignment was robust before allocation of the participants to groups occurred. In two studies (De Chateau 1977; McClellan 1980), allocation concealment was at high risk of bias because the researchers used an open table of random numbers. In seven studies (Anderson 2003; Bergman 2004; Chwo 1999; Moore 2005; Punthmatharith 2001; Shiau 1997; Syfrett 1996), allocation concealment was controlled by using a computer program to assign women to groups (the minimization method). Although the Syfrett 1996 study was small $(n=8)$, the recruiter was naive to the minimization method of random assignment. In 12 studies (Carlsson 1978; Christensson 1992; Christensson 1995; Hales 1977; Kastner 2005; Khadivzadeh 2008; Mazurek 1999; Mizuno 2004; Svejda 1980; Thomson 1979; Vaidya 2005; Villalon 1993), the researchers indicated that women were randomly assigned to groups but no further information was provided about the randomization method. In eight studies (Bystrova 2003; Carfoot 2004; Craig 1982; Curry 1982; Nolan 2009; Sosa 1976a; Sosa 1976b; Sosa 1976c), sealed envelopes were used but the investigators do not state whether the envelopes were sequentially numbered, although Bystrova 2003 noted that the envelopes were opened consecutively. 
Blinding - Blinding women, clinical staff and outcome assessors to treatment group is extremely difficult for this type of intervention, and we found it difficult to judge the impact of lack of blinding on particular outcomes. We have provided a single assessment for performance blinding and detection bias for these studies taking into account both the information provided by investigators, and our assessments of the potential impact of lack of blinding on the particular outcomes measured (i.e. we considered for example, that lack of blinding may have had more impact on outcomes where unblinded outcome assessors observed maternal behavior and less impact on laboratory investigations). In 28 studies we rated the impact of lack of blinding as unclear; in studies where an unblinded investigator provided clinical care for the treatment group and also collected outcome data, we assessed that results may have been more susceptible to observer bias. In the Characteristics of included studies tables we have described for each study any attempts investigators made to blind women, staff and outcome observers.

None of the research reports stated that the delivery and postpartum staff were unaware of the group assignment of the mothers. Ferber 2004, however, stated that the nursery staff were blind to patient group assignment. Therefore, in the majority of studies control for provider performance bias was difficult to determine. In the 10 studies that evaluated infant physiological outcomes (Bergman 2004; Bystrova 2003; Christensson 1992; Fardig 1980; Gouchon 2010; Huang 2006; Mazurek 1999; Nolan 2009; Syfrett 1996; Villalon 1993), however, patient or provider performance bias may not be as significant an issue as it might be with maternal attachment and breastfeeding outcomes. Surprisingly, there was more effort made to control for patient performance bias than for provider performance bias. In seven studies (Carlsson 1978; Craig 1982; Curry 1982; Ferber 2004; Kastner 2005; Svejda 1980; Thomson 1979), it was reported that the women were not aware that they were receiving an experimental treatment and/or they were not informed about the true purpose of the study. Adequate control for patient performance is problematic in the more recent studies because of Institutional Review Board requirements that investigators disclose the true purpose of the study or the experimental conditions, or both. In 14 of the 34 studies, outcome assessors (whenever possible) were reported to be unaware of the woman's group assignment. In several studies, when infant physiological or crying data were obtained by observation during SSC (Bergman 2004; Bystrova 2003; Christensson 1992; Christensson 1995; Fardig 1980; Gouchon 2010; Huang 2006; Mazurek 1999; Syfrett 1996; Villalon 1993), the outcome assessors could not be masked.

Incomplete outcome data-In all but one study (Carlsson 1978), outcome data were either obtained on all the enrolled women or reasons were provided for women who withdrew or had to be withdrawn. Six investigators (Anderson 2003; Bergman 2004; Bystrova 2003; Carfoot 2005; Gouchon 2010; Moore 2005), utilized the Consort Guidelines (Moher 2001; Moher 2010) to document the flow of participants through their clinical trial.

An overall summary of risk of bias for all studies is set out in Figure 1 and 'Risk of bias' findings for individual studies are set out in Figure 2.

\section{Effects of interventions}

All the studies reviewed were randomized controlled trials. Most of our primary and secondary outcomes were measured in only one or two studies and where more studies contributed data there was some heterogeneity between trials. Where we identified moderate or high statistical heterogeneity ( $\mathrm{I}^{2}$ greater than $40 \%$ ), we have drawn attention to this in the text and would urge caution in the interpretation of these results which show the average treatment effect. 
Primary outcomes - breastfeeding rates/duration-Early SSC resulted in better overall performance on several measures of breastfeeding status, although there was heterogeneity between studies.

More SSC dyads were still breastfeeding one to four months postbirth (average risk ratio (RR) 1.27, 95\% confidence interval (CI) 1.06 to 1.53). This meta-analysis included 13 studies and involved 702 mother-infant pairs. In 11 of the 13 studies, SSC dyads were more likely to be breastfeeding at one to four months postbirth, although the difference reached statistical significance in only two studies (Sosa 1976c; Thomson 1979). Overall, there were differences in the size of the treatment effect between studies leading to moderate heterogeneity for this outcome $\left(\mathrm{T}^{2}=0.04, \mathrm{P}=0.03, \mathrm{I}^{2}=47 \%\right.$ ) (Analysis 1.1 ). Much of the heterogeneity was due to a single study (Sosa 1976a) (the study author speculated that variation in treatment effect was due to the particular population attending the study hospital). We carried out a sensitivity analysis removing this study from the analysis; when this study was excluded there was no evidence of statistical heterogeneity $\left(\mathrm{T}^{2}=0.00, \mathrm{P}=\right.$ $0.52, \mathrm{I}^{2}=0 \%$ ) and removing this study had very little impact on the overall treatment effect; the difference between groups favoring the SCC group remained statistically significant (RR $1.31,95 \%$ CI 1.16 to 1.48 ) (Analysis 1.31). As sufficient studies contributed data to this outcome, we generated a funnel plot to explore whether there was any obvious small study effect; Visual examination of the forest and funnel plots suggested that there was a greater treatment effect associated with smaller studies and this may indicate possible publication bias (Figure 3).

Seven studies with 324 mother/infant pairs reported data on the duration of breastfeeding in days. Six of the seven studies (De Chateau 1977; Mizuno 2004; Shiau 1997; Sosa 1976b; Sosa 1976c; Svejda 1980) found a longer duration of breastfeeding in the SSC dyads (mean difference (MD) 42.55 days, $95 \%$ CI -1.69 to 86.79 ). However, overall, the difference between groups did not reach statistical significance. Results from this meta-analysis should be interpreted with caution; there was considerable heterogeneity for this outcome and some of the findings are from studies with very small sample sizes, and although mean duration of breastfeeding was reported this may not have been an appropriate measure in studies where the distribution of scores was unlikely to have been normal (heterogeneity: $\mathrm{T}^{2}=2216, \mathrm{P}=$ $0.007, \mathrm{I}^{2}=66 \%$ ) (Analysis 1.2). Again, it was clear from visual examination of the forest plot that much of the heterogeneity was due to the Sosa 1976a study. Sensitivity analysis excluding this study removed heterogeneity $\left(\mathrm{I}^{2}=0 \%\right)$ and the difference between groups was statistically significant with breastfeeding duration increased by an average of 64 days in the SSC group (MD 63.73, 95\% CI 37.96 to 89.5) (Analysis 1.32).

\section{Infant primary outcomes}

Infant physiological stability in the hours following birth: Bergman 2004 utilized SCRIP scores (a measure of infant cardio-respiratory stability in preterm infants that evaluates infant heart rate, respiratory rate and oxygen saturation) (Fischer 1998) to compare SSC in healthy late preterm $31 \mathrm{SSC}$ infants (mean gestational age $(\mathrm{GA})=34.2$ weeks) with 13 late preterm control infants (mean $\mathrm{GA}=35.3$ weeks) placed in a servo-controlled incubator next to their mothers. SSC infants had higher SCRIP scores during the first six hours postbirth, indicating better stabilization (MD 2.88, 95\% CI 0.53 to 5.23) (Analysis 1.3). A subset of infants below 1800 grams birthweight also demonstrated better stabilization (MD 4.92, 95\% CI -1.67 to 11.51 ) but this result did not reach statistical significance (Analysis 1.4).

Blood glucose 75 to 90 minutes following the birth was measured in two studies with 94 infants; blood glucose was higher in SSC infants (MD $10.56 \mathrm{mg} / \mathrm{dL}, 95 \%$ CI 8.40 to 12.72) and this result was statistically significant (Analysis 1.5). 
Infant thermoregulation: Infant axillary temperature at 90 minutes to two hours after the birth was reported in three studies including a total of 168 dyads. In the studies by Christensson 1992 and Christensson 1995, infants had SSC or were placed in a 'cot' (bassinet) next to the mother during the first 90 minutes postbirth. Neither group of infants was fed. In Villalon 1993 control infants were taken to the nursery. Due to heterogeneity between studies we did not combine results in meta-analysis but results for the individual studies are set out in Analysis 1.6. In the Christensson 1992 and Christensson 1995 studies, results favored the SCC group (RR 0.40, 95\% CI 0.19 to 0.61 , and RR $0.50,95 \%$ CI 0.17 to 0.83 respectively) whereas in the study by Villalon 1993 temperatures were on average slightly higher for the control group at this time point (RR $-0.10,95 \%-0.24$ to 0.04$)$ (although at other time points reported results favored the intervention group and therefore, in view of these inconsistencies findings for this study, are difficult to interpret).

\section{Secondary outcomes}

Breastfeeding outcomes: Two studies with 57 women reported the number exclusively breastfeeding at hospital discharge; there was no evidence of a difference between groups receiving SSC compared with routine care (RR 0.99, 95\% CI 0.66 to 1.47) (Analysis 1.7).

Three studies with 245 women examined breastfeeding status (using the Index of breastfeeding status (IBS) at one month postpartum. The IBS is a single item indicator and consists of three major levels of breastfeeding exclusivity -- full, partial, and token breastfeeding. Full breastfeeding is divided into two sub-categories exclusive and almost exclusive. In almost exclusive breastfeeding, the infant is given water, juice, vitamins and minerals infrequently in addition to breast-milk. Partial breastfeeding is divided into three sub-categories - high, medium and low. Token breastfeeding is occasional and irregular, less than 15 minutes a day.There was no clear evidence of differences between groups for this outcome, and results varied considerably between studies therefore the overall average treatment effect should be interpreted with caution (mean difference (MD) $0.86,95 \%$ CI -0.73 to 2.44 ) (heterogeneity: $\mathrm{T}^{2}=1.70, \mathrm{P}<0.0001, \mathrm{I}^{2}=90 \%$ ) (Analysis 1.8 ).

More infants were exclusively breastfeeding up to three to six months postbirth in three studies $(\mathrm{n}=149)(\mathrm{RR} 1.97,95 \%$ CI 1.37 to 2.83$)$ (Analysis 1.9).

Two studies reported breastfeeding at one year postbirth.There were no statistically significant differences between groups (RR 6.91, 95\% CI 0.82 to 46.78) (Analysis 1.10).

Two studies with 54 women examined breastfeeding effectiveness scores and those in the SCC group had higher mean scores (MD in IBFAT scores 1.79, 95\% CI 0.24 to 3.35) (Analysis 1.11). The Infant Breastfeeding Assessment Tool (IBFAT) evaluates four parameters of infant suckling competence infant state of arousal or readiness to feed; rooting reflex; latch-on; and suckling pattern. The infant can receive a score of 0-3 on each item for a maximum total score of 12 indicating adequate suckling competence (Matthews 1988; Matthews 1991).

Carfoot 2004, Carfoot 2005 and Khadivzadeh 2008 found that infants held SSC were slightly more likely to breastfeed successfully during their first feeding postbirth than those who were held swaddled in blankets by their mothers, although he evidence of a difference between groups was not statistically significant and there was considerable variability between findings in these three studies $(\mathrm{n}=315)$ (average RR 1.36, 95\% CI 0.95 to 1.95; heterogeneity $\mathrm{T}^{2}=0.07, \mathrm{P}=0.03, \mathrm{I}^{2}=72 \%$ ) (Analysis 1.12 ). These findings were obtained using a modification of the IBFAT. 
In a single study with data for 88 women, Bystrova 2003 reported the number of infants that suckled within two hours of the birth; there was no clear evidence of differences between groups (RR $1.06,95 \%$ CI 0.83 to 1.35 ) (Analysis 1.13 ).

Maternal breast temperature: Bystrova 2003 found significant between group differences in the mean variation in breast temperature 30 to 120 minutes postbirth as measured by the interquartile range between mothers who held their infants SSC and those who were separated from their infants (MD 0.60, 95\% CI 0.34 to 0.86) (Analysis 1.14). Duration of SSC was 95 minutes. The researchers suggested that these variations in maternal breast temperature in the SSC group may regulate infant temperature more effectively than stable breast temperatures and help prevent neonatal hypothermia.

Breast problems: Breast engorgement pain (measured by the self-reported Six Point Breast Engorgement Scale (Hill 1994) or by the mother's perception of tension/hardness in her breasts) was less for SSC than non-SSC mothers on day three postbirth (standardized mean difference (SMD) $-0.41,95 \%$ CI -0.76 to -0.06) (Analysis 1.15) (Bystrova 2003; Shiau 1997).

\section{Infant physiological outcomes}

Infant heart rate and respiratory rate: Four studies (Christensson 1992; Mazurek 1999; Nolan 2009; Villalon 1993) obtained data on infant respiratory rate 75 minutes to two hours postbirth. and three studies obtained data on infant heart rate. SSC infants had a lower mean heart rate than control infants who were separated from their mothers although the evidence of a difference between groups did not reach statistical significance and there was high heterogeneity for this outcome (MD -3.05 beats per minute (BPM), 95\% CI -7.84 to 1.75 ; 183 infants); (heterogeneity: $\mathrm{T}^{2}=15.26, \mathrm{P}=0.0005, \mathrm{I}^{2} 87 \%$ ) (Analysis 1.16). Results also favored SCC infants for respiratory rate but again these results did not reach statistical significance and there was considerable variability in findings between studies (MD -3.12 RPM, 95\% CI -6.61 to $0.37 ; 215$ infants) (heterogeneity $\mathrm{T}^{2}=9.24, \mathrm{P}=0.004, \mathrm{I}^{2}=77 \%$ ) (Analysis 1.17). Heterogeneity was mainly due to findings from the Villalon 1993 study; as stated above, findings at different time points varied considerably in this study. We carried out sensitivity analysis where results for this study were excluded; for both heart rate and respiratory rate, removal of findings for Villalon 1993 resulted in statistically significant findings favoring the SCC groups and there was no longer any evidence of between study heterogeneity (heart rate $\mathrm{MD}-5.77,95 \% \mathrm{CI}-7.46$ to -4.11 ; respiratory rate $\mathrm{MD}-4.76$, 95\% CI -6.12 to 3.41) (Analysis 1.33; Analysis 1.34 ).

Bergman 2004 compared the number of infants in the two groups who did not exceed physiological parameters for stability requiring medical attention. The five parameters were infant skin temperature less than $35.5^{\circ} \mathrm{C}$ on two consecutive occasions, heart rate less than 100 or more than 180 BPM on two consecutive occasions, apnea more than 20 seconds, oxygen saturation less than $87 \%$ on two consecutive occasions, blood glucose less than 2.6 $\mathrm{mmol} / \mathrm{L}$ and FIO2 up to 0.6 with continuous positive airways pressure (CPAP) up to $5 \mathrm{~cm}$ of water pressure. Fifteen of the $18 \mathrm{SSC}$ and one of the 13 control infants did not exceed parameters (RR 10.83, 95\% CI 1.63 to 72.02). The most common reasons for exceeding parameters in control infants were hypothermia, hypoglycemia, and respiratory problems (Analysis 1.18).

Neonatal intensive care unit (NICU) admissions: There were no significant differences between groups in infant admissions to the NICU in Bergman 2004. Two SSC infants and one control infant required CPAP and they were transferred to the NICU (RR 1.44, 95\% CI 0.15 to 14.29) (Analysis 1.19).Two studies with 42 infants (Chwo 1999; Syfrett 1996) 
examined hospital length of stay in late preterm infants 34 to 36 weeks' GA and found no significant between group differences and there was high heterogeneity for this outcome (MD -95.30 hours, 95\% CI -368.50 to 177.89) (Analysis 1.22).

Infant body weight change: No statistically significant differences were found in infant body weight change day 14 postbirth; this outcome was reported in two studies with 43 infants (MD -8.00 grams, $95 \%$ CI -175.60 to 159.61) (Analysis 1.20) (Chwo 1999; Moore 2005). Infant weigh change per kilogram per day was not reported in any of the included studies.

Infant crying/behavior: Christensson 1995 found that 12 of the 14 SSC infants cried no more than one minute during the 90-minute observation compared with only one of the 15 control infants (RR 12.86, 95\% CI 1.91 to 86.44) (Analysis 1.23). Mazurek 1999 found that SSC infants cried for a shorter length of time during a 75-minute observation period than control infants (MD -8.01 minutes, $95 \%$ CI -8.98 to -7.04 ) (Analysis 1.24).

\section{Maternal Outcomes}

Maternal-infant bonding: Bystrova 2003 used The Parent-Child Early Relational Assessment (PCERA) in a study with data for 61 women.The PCERA (Clark 1985; Clark 1999) has eight sub-scales evaluating maternal and infant behavior and interaction. Bystrova 2003 found no evidence of significant between group differences for maternal positive affective involvement at 12 months postbirth (MD 1.90, 95\% CI -1.14 to 4.94) (Analysis 1.25) however, SSC dyads appeared more mutual and reciprocal (MD 1.30, 95\% CI 0.24 to 2.36) than those who were separated immediately postbirth and later reunited for rooming-in (Analysis 1.26). Bigelow 2010 under Bergman 2004 found significant effects of SSC during the first 24 hours postbirth on maternal sensitivity to her infant's behavioral cues, which demonstrated a dose-response effect. However it was a small sub-sample (12 of 31 randomized), and the effect was related to the 24-hour dose, with participants randomized to the control condition later receiving SSC, hence excluded from this review.

Other outcomes: Cesarean birth mothers in the SSC group also reported less postoperative pain than mothers who were separated from their infants (MD $-1.38,95 \% \mathrm{CI}-2.79$ to 0.03 ) (Analysis 1.27) (Nolan 2009). Mothers who held their infants SSC indicated a strong preference for the same type of postdelivery care in the future (86\%) whereas only $30 \%$ of mothers who held their infants swaddled indicated that they would most certainly prefer this type of care in the future (RR 2.82, 95\% CI 2.08 to 3.82) (Analysis 1.28) (Carfoot 2005). Mothers who held their infants SSC displayed less state anxiety day three postbirth (MD $-5.00,95 \%$ CI -9.00 to -1.00 ) (Analysis 1.29). Parenting confidence scores were measured in a single study with data for 20 women; there was no evidence of significant differences between groups (MD 5.60, 95\% CI -6.24 to 17.44) (Moore 2005) at one month postbirth between mothers who held their infants SSC or swaddled (Analysis 1.30).

Non-prespecified outcomes: A large number of additional outcomes were measured in the included studies. Most of these outcomes were measured in single studies The clinical importance of results for many such outcomes is difficult to determine. Outcomes which appeared similar were measured in a range of different ways, in addition, many outcomes were reported at different or multiple time points and results may not have been consistent within or between studies. Non-prespecified outcomes reported include observed mother and infant behavior during the first few hours after birth, outcomes relating to breastfeeding (e.g. duration of first feed and number of breastfeeding problems) and a range of outcomes relating to mother-child interaction. 


\section{DISCUSSION}

\section{Summary of main results}

The results of this review demonstrated a statistically significant positive effect of skin-toskin contact (SSC) on the following primary outcomes: breastfeeding one month to four months postbirth, SCRIP score first six hours postbirth, and blood glucose $\mathrm{mg} / \mathrm{dL}$ at 75 to 90 minutes postbirth, We did not identify significant between group differences in duration of breastfeeding, and results relating to infant axillary temperature at 90 minutes to two hours postbirth were difficult to interpret due to high heterogeneity.

We found a statistically significant and positive effect of SSC on the following secondary outcomes: success of the first breastfeeding (IBFAT score), mean variation in maternal breast temperature 30 to 120 minutes postbirth, infant did not exceed physiological parameters for stability, number of babies not crying for more than one minute during a 90minute observation, amount of crying in minutes during a 75-minute observation period and PCERA dyadic mutuality and reciprocity 12 months postbirth. We did not identify significant between group differences in successful first breastfeeding (IBFAT score 10 to 12 or BAT score 8 to 12), infant heart rate 75 minutes to two hours postbirth, infant respiratory rate 75 minutes to two hours postbirth, infant body weight change (grams) day 14 postbirth, transfers to the neonatal intensive care unit, infant hospital length of stay in hours, or PCERA maternal positive affective involvement and responsiveness 12 months postbirth.

No negative outcomes associated with SSC were reported in any of the studies except Sosa 1976a, who reported a longer duration of breastfeeding in the control group.

In summation, the totality of significant outcomes relating to breastfeeding, infant physiology and maternal neurobehavior supports the use of SSC in the early period after birth. However, this overall finding should be treated with some caution: for many outcomes only one or two studies contributed data, and for those outcomes where several studies were combined in meta-analysis there was considerable heterogeneity between individual studies. At the same time, some of those results that did not reach statistical significance were derived from small studies which did not have the statistical power to demonstrate differences between groups.

Breastfeeding/lactation outcomes-Only two breastfeeding meta-analyses contained more that three studies. Thirteen studies (702 infants) reported breastfeeding rates between one and four months postbirth (Analysis 1.1) demonstrating that mothers in the SSC group were more likely to be breastfeeding than those in the control group. The only other outcome with more than three studies (seven studies, 324 infants) was breastfeeding duration (Analysis 1.2). Infants in the SSC group breastfed an average of 42.55 days longer than control infants and when a study with inconsistent results was removed from the analysis the difference between groups was statistically significant. Evidence for breastfeeding exclusivity was conflicting, being no different at hospital discharge (Analysis 1.7, 2 studies) but significantly greater at three to six months postbirth (Analysis 1.9, three studies).The findings of improved breastfeeding for the two largest meta-analyses in this review were obtained in diverse countries and among women of low and high socioeconomic class.

Results for IBFAT scores for the first breastfeeding postbirth were conflicting with one meta-analysis which treated this outcome as a dichotomous variable (Analysis 1.12) demonstrating no significant between group differences and another meta-analysis which used interval level data (Analysis 1.11) finding a significant effect of early SSC. Moore 
2005 also found that SSC and the mother's nipple protractility contributed equally to the variance in infant IBFAT scores. The mother's nipple protractility was important in relation to the infant's ability to establish competent suckling. Dewey 2003 reported that suboptimal breastfeeding behavior during the first 24 hours postbirth was associated with the mother's flat or inverted nipples (RR 1.56). These infants were also 2.6 times more likely to have excessive weight loss.

Timing of when this outcome is measured may be critical because most healthy full term infants spontaneously grasp the nipple and begin to suckle by approximately 55 minutes postbirth. During the first 30 minutes, they may only lick the nipple. Widstrom 2011 found that some infants may take up to 45 minutes to latch after crawling towards and reaching the nipple and recommended that this process should not be disturbed or forced. Also, the intervention will be more successful if a clinician reassures the mother that healthy full term babies are able to crawl to the breast and begin to nurse on their own without assistance when they are ready. After the first two hours postbirth, infants often become sleepy and difficult to arouse.

Babies breastfed more successfully during SSC immediately postbirth than if they were held swaddled in blankets, probably because of the extra tactile, odor, and thermal cues provided by SSC, but this result did not translate into significantly more mothers breastfeeding at one to four months postbirth in two studies by the same investigator (Carfoot 2004; Carfoot 2005). Carfoot 2005 stated that barriers to long-term breastfeeding, such as returning to work, and breastfeeding problems contributed to the minimal effect that early SSC had on this outcome. Early SSC appears to have less of an effect on breastfeeding exclusivity or duration in studies where control infants are held swaddled by their mothers or placed swaddled or clothed on their mother's naked chest and given the opportunity to breastfeed soon after birth than in studies where control infants are separated from their mothers for 12 to 24 hours immediately postbirth. Given the strong evidence of the negative impact of early mother-infant separation, it is noteworthy that in some hospitals usual care still includes this practice for healthy full term newborns (Mizuno 2004).

Moore 2005 suggested that barriers to long-term breastfeeding that exist in the United States, especially the customary absence of, or very brief, paid maternity leave, attenuated the effectiveness of early SSC on breastfeeding status day 28 to one month postbirth (Analysis 1.8). The mothers in Punthmatharith 2001 delivered in a Baby Friendly Hospital in Thailand with 24-hour rooming-in. Control infants were cup fed if they needed supplementation. In addition, most of the SSC took place in extremely warm, un-air conditioned eight-bed postpartum rooms with frequent visitors so that contextual issues, such as body warmth and modesty, may have changed SSC desirability and also effectiveness.

Such factors as room temperature, lack of privacy, modesty, overcrowding, supplemental bottle or pacifier use, and 24-hour rooming-in may play a role in the effectiveness of SSC. Early SSC may not have as strong an effect on long-term breastfeeding in countries with a widespread bottle feeding culture compared to countries with cultures that are supportive of breastfeeding. In the studies by Carfoot 2004, Carfoot 2005, and Moore 2005, mothers in the control group received extra assistance with breastfeeding, which is not always available with usual hospital care. In Moore 2005, the investigator was an experienced lactation consultant who assisted mothers in both groups with initiating breastfeeding. In Carfoot 2005, the midwife usually provided breastfeeding assistance, but if she was unavailable, the research assistant often provided help with breastfeeding. More definitive results might have been obtained if the control groups received only usual hospital care. 
Infant physiological/behavioral outcomes-The between-group differences in SCRIP scores and maintenance of physiological parameters in late preterm infants is certainly clinically significant, especially given the fact that SSC was compared with a servo-controlled incubator. The clinical significance of some of the other physiological outcomes for healthy full term infants is debatable. Full term infants in the SSC group were less than one degree warmer than control infants. Their heart rate was three BPM slower and their respiratory rate was three breaths less per minute, on average. However, their blood glucose was $10.56 \mathrm{mg} / \mathrm{dL}$ higher, a significant finding.The results suggest that early SSC is a safe intervention for healthy infants and that it may increase cardio-respiratory stability, thermal stability, and blood glucose in late preterm infants. Lagercrantz 1986 and Lagercrantz 1996 found that newborn infants experience a catecholamine surge after vaginal birth, caused by compression of the fetal head and intermittent hypoxia during contractions. This response is felt to aid in adaptation to the extrauterine environment immediately postbirth by causing an increase in infant level of alertness, lung compliance, blood glucose, body temperature, and shunting of blood to the vital organs. However, this response may become maladaptive if allowed to continue.These findings correlate accurately with findings predicted from mammalian research on separation in the newborn period. The neurobehavioral stabilization achieved in SSC correlates in mammalian studies with a parasympathetically mediated allostasis, the purpose of which is growth and development. The stabilization achieved in the separated state is mediated by a sympathetically driven defense program, whose purpose is primarily to survive the period of separation. In so far as the differences observed corroborate the findings from mammalian research, they can be considered clinically significant.

The large between-group difference in the amount of crying is certainly clinically significant. Anderson 1989 proposed an evidence-based rationale that maternal-infant separation is associated with excessive infant crying and can be harmful because crying reestablishes portions of the fetal circulation. Each cry cycle causes a bolus of desaturated venous blood to shunt through the foramen ovale into the systemic circulation instead of the lungs, creating hypoxemia. This may result in delayed closure of the foramen ovale or explain the approximately $20 \%$ incidence in apparently normal adults of a permanently patent foramen ovale (estimates in numerous recent studies range from 15\% to 35\% (Del Sette 1998). Anderson 1989 further proposed that crying wastes calories meant for growth, and causes increased and fluctuating cerebral blood flow, cerebral blood flow velocity, and intracranial pressure, thereby increasing the risk of intraventricular hemorrhage in preterm infants. Consequences for healthy full term infants are unknown, but may be similar and correlated with gestational age.

Maternal bonding/attachment: The results of this analysis indicate that SSC may affect maternal attachment behaviors, although the results are mixed. A dose-response relationship may exist as well.

Bystrova 2003 found significant between group differences on two of the eight subscales of the PCERA at 12 months postbirth. The effects of rooming-in on these outcomes did not compensate for a short (120 minutes) period of separation.

These findings would make sense from the perspective of programming (Lucas 2005) and early evolution, where human mothers would be expected to form a rapid attachment to their infants to protect them from predators and to provide the high level of parental care necessary for such physiologically immature newborns. However, it is important to document how many infants in the SSC group breastfed and how effectively they nursed. Breastfeeding during SSC stimulates the secretion of hormones such as oxytocin that promote maternal attachment and prolactin which promotes lactation and, at least in rodents, 
maternal behavior. Breastfeeding has been considered an integral part of the intervention in Kangaroo Mother Care research in low- and middle-income countries. In this review, breastfeeding has been considered an outcome and SSC the habitat that elicits this outcome. However, mothers would logically nurse their infants soon after birth in early human evolution. Early and effective breastfeeding while in SSC may increase the strength of this intervention with respect to maternal attachment behaviors.

\section{Overall completeness and applicability of evidence}

The available evidence does address the review question, but seldom abides by any clear definition of acceptable public health breastfeeding outcomes. Only Anderson 2003; Moore 2005; Punthmatharith 2001; and Shiau 1997 used breastfeeding status (Labbok 1990) to measure the degree of breastfeeding exclusivity. In all the other studies, breastfeeding was considered a dichotomous variable. The infant was either breastfeeding (yes/no) or exclusively breastfeeding (yes/no). Further, the actual intervention in terms of timing and duration of SSC was highly variable, and at times very short. Despite this, the evidence is fairly consistent in supporting the effect of SSC in so far as the findings are numerous and pooled findings were consistently in favor of SSC and show moderate effects. However, for many outcomes findings were from individual studies: the variety of outcomes measured and the lack of consistency in the way outcomes were measured meant that meta-analysis was not appropriate.

The high levels of heterogeneity between studies could possibly reflect bias with selective outcome reporting, with data reported on the basis of post-hoc observations rather than predefined public health outcomes. Another possible source of bias concerns the quality of breastfeeding support provided, and whether this was controlled for adequately between groups. In some instances, co-interventions were added to SSC that make it difficult to disentangle the effects of SSC from the other interventions.

The variability in outcomes reported, instruments used, context, and timing made it difficult to combine many of the attachment outcomes for meta-analysis. Because of these methodological limitations, the overall quality of the evidence is again considered moderate.

\section{Quality of the evidence}

The presently available evidence has a number of limitations.

(1) Design limitations-All studies were randomized controlled trials. However, the methodological quality of trials was mixed. Overall, the quality of reporting on study methods was poor. For the majority of trials we did not have sufficient information on the methods used to carry out randomization to allow us to assess whether findings were at high risk of bias. A particular problem in all of the included studies was the lack of blinding. SSC cannot be implemented masked, but the assessment of physiologic changes or outcomes can often be carried out by individuals masked to allocation but overall it is very difficult to judge the impact of lack of blinding or only partial blinding on findings. It is possible that differences in the care women received in SSC and control groups were not confined to whether or not they had early SSC. In some studies the staff providing care to the two groups were different, and in these cases it is possible that the overall care experience for women in different arms of trials was not the same, and it may be that aspects of care other than, or in addition to, SSC led to reported differences between groups. This may have been compounded by the fact that in some studies the same staff delivering interventions also measured outcomes. Outcomes such as observed maternal and infant behavior may have been susceptible to detection bias. The impact of lack of blinding may have been less for some of the outcomes measured, for example, some infant physiological outcomes however, 
even outcomes such as infant temperature may be affected by bias in staff collecting outcome data.

(2) Outcome variability-Meta-analysis was limited in this review, due to the numerous outcomes and the limited number of randomized trials that could be included for each outcome. Although many of the studies measured broadly similar outcomes, the outcomes were too dissimilar to be included in a meta-analysis. In some studies, means were reported without standard deviations, or exact $\mathrm{P}$ values, or both. The context, the instruments used, and the timing of the measurement of attachment and temperature outcomes varied greatly among studies. Breastfeeding was measured as a dichotomous variable in some studies or as an interval level measure of breastfeeding exclusivity in four. Modality for measurement of temperature outcomes varied between studies. These contextual and measurement differences should be noted when considering the results of the review.

\section{Potential biases in the review process}

We are aware that the review process may be affected by bias; and we attempted to minimize bias in a number of ways. At least two review authors independently assessed study eligibility, carried out data extraction, and assessed risk of bias. However, some aspects of the review process involve subjective judgements: assessing risk of bias in included studies, for example, is not an exact science, and it is possible that a different review team may have reached different conclusions about the quality of the evidence. We have attempted to explain our decisions regarding study quality in the 'Risk of bias' tables. We have also provided details about the participants and interventions in individual studies and we would encourage readers to interpret results in the light of the information set out in the Characteristics of included studies tables.

\section{Agreements and disagreements with other studies or reviews}

The findings are in general agreement with results from other studies mentioned in this review notably Bramson 2010. This large hospital-based study $(n=21,842)$ demonstrated a clear dose-response effect on exclusive breastfeeding at hospital discharge. The data from this review, although suggestive, are inadequate to demonstrate a dose-response effect. Although the modality and timing of measurement of infant temperature varied between studies, this review found minimal increases in temperature with SSC although the results were often not statistically significant. These results support those obtained Mori 2010 who found a mean increase of 0.22 degrees $C$. in a meta-analysis of 21 studies of infant temperature pre SSC compared with during the intervention. Mori 2010 found an increase in infant heart rate of 2.04 BPM in a meta-analysis of 12 studies of preterm infants pre versus during SSC. The process of transferring a preterm infant from a radiant warmer or isolette to SSC and back again can be somewhat stressful and may account for these findings. The length of SSC in some of the included studies was very short, 15 minutes in one study, 30 minutes in another. This review found a decrease in infant heart rate of 3.05 in between group comparisons of early SSC with usual care. However, the findings were not clinically significant. We assess the methodological quality of the evidence as moderate because these studies have the same limitations as those with breastfeeding outcomes; small samples, varied contexts and heterogenous outcomes.

\section{AUTHORS' CONCLUSIONS}

\section{Implications for practice}

Breastfeeding outcomes-this review does provide evidence to support current practices as recommended by the UNICEF endorsed Baby Friendly Hospital Initiative, in which SSC is encouraged for the first hour after birth. There is, however, inadequate 
evidence with respect to details such as timing of initiation, dose of skin-to-skin contact (SSC) and technique. This review does not address subsequent ongoing SSC as an intervention to support breastfeeding. It is, however, noteworthy that an intervention practiced for a short time at birth should have measurable breastfeeding effects one to four months postbirth.

Infant outcomes-the significant increase in blood glucose, and maintenance of infant temperature in the neutral thermal range are both clinically important, and lend support to current American Academy of Pediatrics recommendations for the use of SSC in the first hour after birth (American Academy of Pediatrics 2005). Clearly there is a relationship between improved breastfeeding and higher blood glucose. In terms of evolutionary biology, and mammalian studies, this higher value may in fact be the norm, and a lowering may reflect the autonomic nervous system evoking a separation distress response, consuming excess calories (Christensson 1995). This is further supported by the significantly increased crying seen in separation versus SSC (three studies). The decreased crying is in itself clinically important for other reasons as described in the background (Ludington-Hoe 2002). Late-preterm infants are at increased risk for hypoglycemia and hypothermia which can worsen any symptoms of respiratory distress (Raju 2006).

The SCRIP score attempts to provide a composite measure of cardiorespiratory stability. Only one study reported this, with significant benefit in favor of SSC, providing further support for the use of early SSC. While differences in particular cardiorespiratory outcomes are evident, these are open to different interpretations, and mean little without a sense of trend and direction in terms of stabilization and physiological self-regulation.

Although a number of the infant physiological outcomes, (except SCRIP scores, blood glucose, infant crying, and maintenance of physiological parameters), demonstrated little or no clinically significant differences with or without SSC, no negative short- or long-term effects were found. Based on the available evidence, SSC appears to have some clinical benefit, especially for temperature and cardio-respiratory stability in late preterm infants.

Attachment outcomes-despite the variability in dose and timing of the intervention, there is at least a small effect on several dimensions of maternal neurobehavior in relation to her infant. This is consistent with evolutionary biology theory, in which infant survival depended on an immediate care-giving imperative. There is no benefit shown in any study from infants being separated.

The main results of the meta-analysis, and from the single studies, indicate that SSC appears to have a positive effect on breastfeeding one to four months postbirth, blood glucose, infant crying and on infant temperature stability. These benefits of early SSC can be discussed with mothers and their partners during prenatal visits and mothers can be encouraged to incorporate early SSC into their birth plans. The timing of the intervention may be important, because most infants are very alert in the first two hours postbirth and, if undisturbed and unmedicated, will self-attach to the nipple, and do so correctly, at approximately 55 minutes postbirth. However, Widstrom 2011 noted that it may take some infants up to 45 minutes to latch after they reach the mother's nipple.The temperature of a healthy newly delivered infant will remain in a safe range, provided ventral-to-ventral SSC is uninterrupted; the infant is thoroughly dried and covered across the back with a prewarmed blanket; and the head is covered with a dry cap that is replaced if it becomes damp. These practices need to be incorporated into hospital routines along with the stipulation that mothers and newborn infants should not be left alone and unattended by medical personnel in the delivery or recovery room during this transitional period (Dageville 2008). 


\section{Implications for research}

Interpreting the findings of this review was hampered by the large number of outcomes reported in included studies and inconsistency in the way outcomes were measured. We have reported results for 31 pre-specified outcomes, however, the included studies reported many other outcomes, measured in different ways, reported at different (and sometimes multiple) time points. This lack of consistency was a particular problem for outcomes relating to mother and infant behavior and mother-infant interaction.

Breastfeeding outcomes-suggestions for improvement of clinical trials examining early skin-to-skin contact (SSC) and breastfeeding outcomes include the following. The mother's prenatal breastfeeding intention (how long she planned to nurse her infant) was not controlled in any study except Punthmatharith 2001 and Moore 2005. Only Carfoot 2004; Carfoot 2005; Gouchon 2010; Khadivzadeh 2008 and Moore 2005 evaluated the success of the first breastfeeding in both the SSC and control groups using a published breastfeeding observation instrument, the IBFAT. A valid measure of effective suckling at a single feeding remains elusive (Riordan 1997) and is needed to identify problems in time to minimize breastfeeding attrition; this would be a major contribution to the field. It remains difficult to disentangle the effects of early SSC from the effects of assistance provided by an experienced nurse with the first breastfeeding. The protractility of the mother's nipples is a potential confounding factor that could influence breastfeeding outcomes Dewey 2003 and should be measured in future studies that evaluate breastfeeding and infant suckling patterns. The use of SSC to facilitate breastfeeding for mothers who are having breastfeeding difficulties requires further evaluation. Future research should use standardized public health measures, such as the Index of Breastfeeding Status (IBS) rather than, or in addition to, measuring breastfeeding as a dichotomous variable.

Infant outcomes-rigorous and validated composite measures of physiological benefit are not yet available in the literature. Until better and validated scores or measures for stabilization are presented, we recommend the use of the SCRIP score as a primary outcome measure in studies on early SSC. There is also a clear need for dose-response studies: the intervention of SSC is applied in small doses in many studies. As described in the introduction, in animal studies, the dose of separation is accurately measured and correlated with harmful effects (Poletto 2006; Ziabreva 2003). Further, it is possible that the physiological benefit demonstrated is only as lasting as the actual intervention; therefore, clinical benefit may require prolonged or continuous use of SSC.

Attachment outcomes-improvement is needed in examining maternal attachment behaviors. These studies are all weakened by the lack of consistency in the measurement of these variables. Each research team appeared to have its own ideas about how to operationally define attachment behavior. More recent studies (Anderson 2003; Bystrova 2003) have begun to use more rigorously validated instruments such as the NCAST feeding and teaching scales and the PCERA. No information was provided in the research reports about how many infants successfully breastfed in either group using a validated measurement instrument such as the IBFAT.

Future investigations are recommended because the methodological quality of the included studies is marginally adequate, the characteristics of the SSC and control conditions are diverse, and many outcome measures are difficult to combine. Only four studies (Anderson 2003; Bergman 2004; Chwo 1999; Syfrett 1996) examined the effects of early SSC on late preterm infants who were judged healthy enough to remain on the postpartum ward. The effects of this intervention may be different in this more vulnerable population, and more research is definitely indicated. More research needs to be conducted on the effects of early 
SSC on mothers who deliver by cesarean birth. To facilitate meta-analysis of the data, future research in this area should involve outcome measures consistent with the best measures used in previous studies or measures developed recently to increase methodological rigor (Anderson 2004b; Labbok 1990). The CONSORT guidelines (Moher 2001; Moher 2010) should be used to document the flow of participants through all clinical trials. Studies should make explicit SSC initiation time, frequency and duration to investigate a possible doseresponse relationship.

To improve the methodological quality and reporting in similar clinical trials would be relatively easy. Investigators can provide more details in research reports regarding the method and timing of random assignment, allocation concealment scheme, measures used to control for selection bias, context, timing, and modality of outcome measurements, and means and standard deviations for the interval or ratio level outcome variables examined. However, control for provider and patient performance bias may continue to be problematic, because Institutional Review Boards now require investigators to disclose the purpose of their study to potential participants so they can be informed when they consent to random assignment. Labor and delivery room staff often ask for group assignment of women before delivery so that they will know how to manage the infant immediately postbirth. Outcome assessors should be blinded, however, if at all possible (Polit 2011). Speaking more generally, recommendations by Thomson 1984 provide guidelines for well-controlled clinical trials that remain important to this day.

\section{Acknowledgments}

We thank Dr Busakorn Punthmatharith for her contributions during the earliest phases of the literature review; Dr Mark W Lipsey for his assistance with the categorization of outcome measures for meta-analysis; and Dr Joseph Hepworth for his statistical assistance with the original review. We would also like to thank Anna Fangrath and Lindsay Irish for the English translation of Kastner 2005 and Dr Sheau-Huey Chiu and Danni Li for the translation of Huang 2006. Dr Moore would like to thank Angela Aaron, Ashley Arnold, Candice Bruce, Erin DeBruyn, Monique Deterville, Erin Empting, Kristen McGriff, Jaclyn Miller, Shaunna Parker, Lindsay Piper, Carrie Schrimsher, Lucie Slapnicka, Anna Storvick and Melissa Young, former Women's Health Nurse Practitioner students at Vanderbilt University School of Nursing, for their assistance with reviewing the articles for the updated review, and with completing the Characteristics of included studies tables under the careful supervision and with the guidance of Dr Moore.

\section{SOURCES OF SUPPORT}

Internal sources:

- $\quad$ None, Not specified.

External sources:

- Therese Dowswell is supported by the NIHR NHS Cochrane Collaboration Programme grant scheme award for NHS-prioritised centrally-managed, pregnancy and childbirth systematic reviews: CPGS 10/4001/02, UK.

\section{Appendix 1: The International Network for Kangaroo Mother Care}

The International Network maintains a bibliography of all the research articles published on KangarooMother Care. The bibliography is available from Dr Susan Ludington Susan.ludington@.case.edu

\section{Appendix 2: Methods used to assess trials included in previous versions of this review}

Each study that we identified as a result of the search strategy was evaluated independently for inclusion in the review by two review authors. We rejected trials without a concurrent 
control group (e.g. those with historical controls). We included relatively high quality quasirandomized studies in the review. If the assignment to groups appeared to create equivalent groups, then the study was included even if a truly random process was not used for group assignment. For example, if women were alternately assigned to treatment and control groups and there was no reason to think that this should result in nonequivalent groups, that study was included. On the other hand, if assignment to groups was based on woman or provider preference, the study was excluded. Studies conducted by each of the three authors were reviewed for inclusion by the other two authors and a consensus was reached regarding inclusion of these studies in the review. Methods used for generation of the randomization sequence were described for each trial.

Each identified trial was assessed for methodological quality with respect to (1) selection bias, (2) attrition bias, and (3) performance bias. We assigned a quality score for each trial, using the following criteria.

\section{(1) Selection bias (allocation concealment)}

A. Adequate concealment of allocation: centralized randomization, sequentiallynumbered, sealed opaque envelopes, computerized minimization technique;

B. unclear whether adequate concealment of allocation: sealed envelopes but not sequentially numbered or opaque, a trial in which description suggests adequate concealment but other features suspicious, e.g. markedly different treatment and control groups, stated random but unable to obtain further details;

C. inadequate concealment of allocation: any allocation procedure transparent before assignment, such as open list of random-number tables, use of case record numbers, dates of birth or days of the week.

\section{(2) Attrition bias}

We assessed completeness to follow up using the following criteria: complete follow up of all study participants/reasons given for attrition/NSD between participants who terminated their involvement in the study and those who remained enrolled (yes/no/unclear).

\section{(3) Performance bias}

We assessed blinding using the following criteria:
A. blinding of participants (yes/no/unclear);
B. blinding of caregiver (yes/no/unclear);
C. blinding of outcome assessment (yes/no/unclear).

We designed a form to extract data. Several review authors extracted data and assessed the methodological quality of each study independently and compared results. Disagreements about study inclusion and methodological quality were resolved through discussion until a consensus was reached. We reviewed the inclusion criteria and therapeutic interventions for each trial to see how they differed between trials. We examined the outcomes in each trial to see how comparable they were between studies. We contacted investigators (if possible) to obtain information about any missing data. For categorical data, we made $2 \times 2$ tables from each trial for each important outcome, and used odds ratios with $95 \% \mathrm{CI}$ in the metaanalysis. For continuous variables, we calculated weighted mean differences with $95 \%$ CI. We used standardized mean differences to combine trials that used different scales to measure the same outcome. We used fixed-effect meta-analysis for combining data in the 
absence of significant heterogeneity. We used random-effects meta-analysis for trials with significant heterogeneity identified by using the $\mathrm{I}^{2}$ statistic. We were unable to explore heterogeneity using subgroup analysis or sensitivity analysis because there were not enough clinical trials included for the heterogeneous outcomes.

\title{
CHARACTERISTICS OF STUDIES
}

\section{Characteristics of included studies [ordered by study ID]}

\author{
Anderson 2003
}

\begin{tabular}{|c|c|c|}
\hline Methods & \multicolumn{2}{|c|}{ Randomized controlled trial (computerized minimization technique) } \\
\hline Participants & \multicolumn{2}{|c|}{$\begin{array}{l}91 \text { healthy preterm infants } 32-36 \text { weeks' gestation and their mothers. Only data from the } 31 \text { infants } \\
\text { on the postpartum unit were included in the analysis; the } 60 \text { NICU infants were excluded. Mean GA } \\
\text { of the included infants was } 35.6 \text { weeks. There were no significant between group differences in } \\
\text { socio- demographic or medical characteristics in this sub-group of infants except } 5 \text {-min Apgar } \\
\text { scores. The mean 5-min Apgar score was } 9.0 \text { in the SSC group and } 8.5 \text { in the control group }\end{array}$} \\
\hline Interventions & \multicolumn{2}{|c|}{$\begin{array}{l}\text { 1) SSC group = diaper clad infants placed prone and SSC between their mother's breasts as soon as } \\
\text { possible for as long as possible postbirth. Along with SSC, mothers also held their infants wrapped } \\
\text { in blankets. 2) Control group = infants kept warm in incubators, warmer beds, bassinets or held } \\
\text { wrapped in blankets } \\
\text { Process outcomes include mean \% contact time during hours } 0-48 \text { spent in SSC or wrapped holding } \\
\text { by mother, father or others and mean \% noncontact time (no hold) hours } 0-48 \text { postbirth }\end{array}$} \\
\hline Outcomes & \multicolumn{2}{|c|}{$\begin{array}{l}\text { Mother preterm infant interaction (MPI) measured by mean scores on the Nursing Child } \\
\text { Assessment Satellite Training Program (NCAST) Feeding and Teaching scales at } 6,12 \text { and } 18 \\
\text { months postbirth (reported in Chiu } 2009 \text { using the same data set). Breastfeeding status (exclusivity) } \\
\text { at hospital discharge, } 6 \text { weeks, } 3,6,12 \text { and } 18 \text { months postbirth (reported in Hake-Brooks } 2008 \\
\text { using the same data set) }\end{array}$} \\
\hline Notes & \multicolumn{2}{|c|}{$\begin{array}{l}\text { Study was done in the USA at } 2 \text { different hospitals } 1 \text { on Cleveland, Ohio and the other in Richland, } \\
\text { Washington. Participants were mixed parity }\end{array}$} \\
\hline \multicolumn{3}{|l|}{ Risk of bias } \\
\hline Bias & Authors' judgement & Support for judgement \\
\hline $\begin{array}{l}\text { Random } \\
\text { sequence } \\
\text { generation } \\
\text { (selection bias) }\end{array}$ & Low risk & Randomization was by a computerized minimization program. \\
\hline $\begin{array}{l}\text { Allocation } \\
\text { concealment } \\
\text { (selection bias) }\end{array}$ & Low risk & $\begin{array}{l}\text { Sealed, sequentially numbered opaque envelopes containing the next group } \\
\text { assignment were used for the first } 10 \text { participants to prevent selection bias. } \\
\text { The rest of the participants were assigned to groups using the minimization } \\
\text { technique. Informed consent was obtained during early labor Mother-infant } \\
\text { dyads were randomly assigned to groups immediately postbirth }\end{array}$ \\
\hline $\begin{array}{l}\text { Blinding } \\
\text { (performance } \\
\text { bias and } \\
\text { detection bias) } \\
\text { All outcomes }\end{array}$ & Low risk & $\begin{array}{l}\text { The research staff involved in evaluating MPI data at } 6,12 \text { and } 18 \text { months } \\
\text { postbirth using a videotaped infant feeding and teaching session were } \\
\text { unaware of the mother's group assignment } \\
\text { The nurse researcher who collected Index of Breastfeeding Status (IBS) } \\
\text { scores was blind to participant group assignment }\end{array}$ \\
\hline $\begin{array}{l}\text { Incomplete } \\
\text { outcome data } \\
\text { (attrition bias) } \\
\text { All outcomes }\end{array}$ & Low risk & $\begin{array}{l}\text { At } 6 \text { months postbirth, } 2 / 15 \text { infants were missing from the SSC group and } \\
2 / 14 \text { from the control group; at } 12 \text { months postbirth } 2 / 15 \text { infants were } \\
\text { missing from the SSC group and } 2 / 14 \text { from the control group, at } 18 \text { months } \\
\text { postbirth } 3 / 15 \text { infants were missing from the SSC group and } 2 / 14 \text { from the } \\
\text { control group. At } 3 \text { and } 6 \text { months postbirth } 1 / 11 \text { breastfeeding SSC infants } \\
\text { had missing data on the IBS. At } 6 \text { weeks postbirth } 1 / 12 \text { breastfeeding } \\
\text { control infants had data missing on the IBS, at } 3 \text { months postbirth } 3 / 12 \\
\text { infants had missing data }\end{array}$ \\
\hline $\begin{array}{l}\text { Selective } \\
\text { reporting } \\
\text { (reporting bias) }\end{array}$ & Low risk & $\begin{array}{l}\text { Numerical data (M,SD) were reported by group assignment for the } \\
\text { NCAST feeding scales at } 6 \text { and } 12 \text { months, and the NCAST teaching } \\
\text { scales at } 6,12 \text { and } 18 \text { months postbirth } \\
\text { Numerical data were reported for the IBS N,n, \% in each breastfeeding } \\
\text { category at hospital discharge, } 6 \text { weeks postbirth and at 3,6,12 and } 18 \\
\text { months postbirth }\end{array}$ \\
\hline
\end{tabular}


Other bias Unclear risk

In the SSC group the nurse researchers provided breastfeeding assistance with the initial feedings. The control mothers received standard hospital care. Lactation consultants provided breastfeeding assistance if the mother requested help and if they were available

\section{Bergman 2004}

\begin{tabular}{|c|c|c|}
\hline Methods & \multicolumn{2}{|c|}{ Randomized controlled trial (computerized minimization technique) } \\
\hline Participants & \multicolumn{2}{|c|}{$\begin{array}{l}35 \text { healthy late preterm infants and their mothers. Mean GA SSC group } 34.2 \text { weeks, control group } \\
35.3 \text { weeks }\end{array}$} \\
\hline Interventions & \multicolumn{2}{|c|}{$\begin{array}{l}\text { All infants had a brief period of SSC immediately postbirth. 1) SSC group = after the 5-min Apgar } \\
\text { the naked infant was secured to their mother's chest by a towel. A shirt with long ties was placed } \\
\text { around the mother's waist to secure the baby below. The dyad was transferred to the observation } \\
\text { area of the neonatal unit at } 60 \text { min postbirth. SSC was continuous for at least } 6 \text { hours } 2 \text { ) Control } \\
\text { group = after the 5-min Apgar the infant was transferred to an incubator which remained with the } \\
\text { mother in the delivery room for } 60 \text { min. At } 1 \text { hour the infant in the incubator was transferred to the } \\
\text { observation area of the neonatal unit }\end{array}$} \\
\hline Outcomes & \multicolumn{2}{|c|}{$\begin{array}{l}\text { Transfers to NICU, exceeded parameters }- \text { temp }<35.5 \text {, HR }<100>180 \text { BPM, Apnea }>20 \text { s, O2 sat } \\
<89 \% \text {, blood glucose }<2.6 \text {, SCRIP score during the first } 6 \text { hours postbirth, SCRIP score in the } 6 \text { th } \\
\text { hour postbirth }\end{array}$} \\
\hline Notes & \multicolumn{2}{|c|}{$\begin{array}{l}\text { Study was done with indigent participants in } 2 \text { secondary level referral hospitals in Cape Town, } \\
\text { South Africa }\end{array}$} \\
\hline \multicolumn{3}{|l|}{ Risk of bias } \\
\hline Bias & Authors' judgement & Support for judgement \\
\hline $\begin{array}{l}\text { Random } \\
\text { sequence } \\
\text { generation } \\
\text { (selection bias) }\end{array}$ & Low risk & $\begin{array}{l}\text { "computerized minimisation method". Range of factors taken } \\
\text { into account in the minimization process in an attempt to } \\
\text { reduce confounding }\end{array}$ \\
\hline $\begin{array}{l}\text { Allocation } \\
\text { concealment } \\
\text { (selection bias) }\end{array}$ & Low risk & $\begin{array}{l}\text { Computerized method of allocation following ascertainment } \\
\text { of eligibility ( } 5 \text {-min Apgar score) by nurse researcher present } \\
\text { at delivery or by mobile phone. }\end{array}$ \\
\hline $\begin{array}{l}\text { Blinding } \\
\text { (performance } \\
\text { bias and } \\
\text { detection bias) } \\
\text { All outcomes }\end{array}$ & Unclear risk & $\begin{array}{l}\text { Women and staff present during intervention would be aware } \\
\text { of allocation but, it is not clear whether this was likely to } \\
\text { have had an impact on most of the types of outcomes } \\
\text { measured and there was an attempt to standardize other } \\
\text { aspects of care. The nurse carrying out randomization was } \\
\text { involved in other aspects of care such as breastfeeding } \\
\text { instruction. For many outcomes reported (physiological } \\
\text { measurements) most were continuously recorded on } \\
\text { monitors and unlikely to have been subject to bias. Clinical } \\
\text { decisions re admission to NICU could not be standardized }\end{array}$ \\
\hline $\begin{array}{l}\text { Incomplete } \\
\text { outcome data } \\
\text { (attrition bias) } \\
\text { All outcomes }\end{array}$ & Low risk & $\begin{array}{l}35 \text { randomized. } 1 \text { woman in the intervention group was } \\
\text { excluded postrandomization as she was no longer eligible. } \\
\text { The remaining } 34 \text { remained available for the primary } \\
\text { outcome (NICU admission) and the remaining } 31 \text { were } \\
\text { followed up for } 6 \text { hour measurements. Intention-to-treat } \\
\text { analysis for primary outcome }\end{array}$ \\
\hline $\begin{array}{l}\text { Selective } \\
\text { reporting } \\
\text { (reporting bias) }\end{array}$ & Unclear risk & $\begin{array}{l}\text { Not apparent, although risk of bias was carried out using } \\
\text { published study report }\end{array}$ \\
\hline Other bias & Unclear risk & $\begin{array}{l}\text { The initial power calculation suggested a sample size of } 64 \\
\text { and the investigators planned to recruit } 100 \text { women. There } \\
\text { were logistical difficulties in recruitment that may have led } \\
\text { to selection biases and this may reduce the generalizability of } \\
\text { findings. The } 2 \text { study groups were of different sizes; this } \\
\text { occurred by chance. Difficulties in recruitment led to interim } \\
\text { analysis and as results favored the intervention group, the } \\
\text { study was discontinued } \\
\text { Baseline imbalance: not apparent. }\end{array}$ \\
\hline
\end{tabular}

Cochrane Database Syst Rev. Author manuscript; available in PMC 2014 April 08. 


\section{Bystrova 2003}

\begin{tabular}{|c|c|c|}
\hline Methods & \multicolumn{2}{|c|}{ Randomized controlled trial (envelope with group assignment) } \\
\hline Participants & \multicolumn{2}{|c|}{176 healthy full term infants and their mothers were divided into 4 treatment groups } \\
\hline Interventions & \multicolumn{2}{|c|}{$\begin{array}{l}\text { All infants were immediately placed under a radiant warmer, dried, washed, weighed, given eye } \\
\text { prophylaxis and cord care during the first } 22 \text { min postbirth. } \\
\text { 1) SSC group = } 37 \text { babies were placed prone and SSC on mother's bare chest for approximately } 90 \\
\text { min and then roomed-in (swaddled or dressed) on the maternity ward and breastfed on demand. } 2 \text { ) } \\
\text { Mother's arms group = } 40 \text { babies were clothed (swaddled or dressed) and placed prone on their } \\
\text { mother's bare chest. for approximately } 90 \text { min and then roomed-in on the maternity ward and } \\
\text { breastfed on demand. 3) Nursery group = } 38 \text { babies were clothed (swaddled or dressed) and taken to } \\
\text { the nursery immediately postbirth and remained there while their mothers were on the maternity } \\
\text { ward except for breastfeeding } 7 \text { times a day. 4) Reunion Group = } 38 \text { babies were clothed (swaddled } \\
\text { or dressed) and taken to the nursery immediately postbirth, but roomed-in with their mothers on the } \\
\text { maternity unit and breastfed on demand }\end{array}$} \\
\hline Outcomes & \multicolumn{2}{|c|}{$\begin{array}{l}\text { Mean difference in infant axillary, interscapular, thigh temperatures and foot temperature change } \\
\text { from } 30 \text { to } 120 \text { min postbirth (Bystrova 2003). Amount of milk ingested (before and after } \\
\text { breastfeeding infant weights), volume of supplemental feedings, number and duration of } \\
\text { breastfeedings day } 4 \text { postbirth, recovery of infant weight loss day 3-5 postbirth (reported in Bystrova } \\
\text { 2007a). Number of breastfeedings, physiological breast engorgement, feeling low/blue days } 1-3 \\
\text { postbirth, duration of nearly exclusive breastfeeding (reported in Bystrova 2007b). Maternal breast } \\
\text { and axillary temperature, (reported in Bystrova 2007c). Assessment of mother-child interaction at } 12 \\
\text { months postbirth using the Parent-Child Early Relational Assessment (PCERA) (reported in } \\
\text { Bystrova 2009). }\end{array}$} \\
\hline Notes & \multicolumn{2}{|c|}{ Study was done in St Petersburg, Russia. } \\
\hline \multicolumn{3}{|l|}{ Risk of bias } \\
\hline Bias & Authors' judgement & Support for judgement \\
\hline $\begin{array}{l}\text { Random } \\
\text { sequence } \\
\text { generation } \\
\text { (selection bias) }\end{array}$ & Low risk & $\begin{array}{l}\text { An experimental } 2 \text { factor design (baby's location, apparel) was used. The } \\
\text { randomization sequence was blocked for time and parity. Randomization to } \\
\text { the } 8 \text { treatment combinations occurred in blocks of } 8 \text { mothers independent } \\
\text { of the other blocks and separated by parity }\end{array}$ \\
\hline $\begin{array}{l}\text { Allocation } \\
\text { concealment } \\
\text { (selection bias) }\end{array}$ & Low risk & $\begin{array}{l}\text { Informed consent was obtained during labor. Random assignment occurred } \\
\text { immediately after birth. Sealed, numbered, opaque envelopes were opened } \\
\text { sequentially. The research report stated that "both the researchers and the } \\
\text { recruited women were blind to the task" }\end{array}$ \\
\hline $\begin{array}{l}\text { Blinding } \\
\text { (performance } \\
\text { bias and } \\
\text { detection bias) } \\
\text { All outcomes }\end{array}$ & Unclear risk & $\begin{array}{l}\text { The psychologists who evaluated videotaped mother-child interactions at } 12 \\
\text { months postbirth using the PCERA were blind to group assignment. The } \\
\text { videotaping was also performed by a psychologist who was blind to group } \\
\text { assignment. No information was provided about whether the researchers } \\
\text { who evaluated the other outcomes in these research reports were blind to } \\
\text { group assignment. The evaluators of some of the outcomes, for example, } \\
\text { infant temperatures taken during SSC, could not be blind to group } \\
\text { assignment }\end{array}$ \\
\hline $\begin{array}{l}\text { Incomplete } \\
\text { outcome data } \\
\text { (attrition bias) } \\
\text { All outcomes }\end{array}$ & Low risk & $\begin{array}{l}176 \text { mothers were randomly assigned to the } 4 \text { main treatment groups. } 23 \\
\text { mothers were excluded during their stay on the maternity ward for various } \\
\text { reasons which were listed in the research report. There were no significant } \\
\text { between group differences in background variables between the } 23 \text { mothers } \\
\text { who were excluded and the } 153 \text { who remained in the study. } 9 \text { mothers were } \\
\text { lost to follow-up at } 1 \text { year. Reasons for their exclusion were provided. An } \\
\text { additional } 20 \text { mother-infant pairs were excluded from the PCERA } \\
\text { assessments } 12 \text { months postbirth. Reasons for their exclusion were provided }\end{array}$ \\
\hline $\begin{array}{l}\text { Selective } \\
\text { reporting } \\
\text { (reporting bias) }\end{array}$ & Low risk & $\begin{array}{l}\text { Numerical data were provided for all outcomes except recovery of infant } \\
\text { weight loss day 3-5 postbirth (Bystrova 2007a) however, between the } 4 \\
\text { groups, differences were reported to be insignificant. The results of the } \\
\text { statistical tests and P values were reported for all outcomes in Bystrova, } \\
\text { IBJ, 2007). However, the M, SE was used instead of M, SD for the } \\
\text { descriptive statistics. Data for the mean maternal axillary and breast } \\
\text { temperatures were plotted on a graph for the } 7 \text { time points for data } \\
\text { collection in Bystrova } 2007 \mathrm{c} \text {. The SE rather than the SD was used as the } \\
\text { measure of dispersion. Data for the infant's foot and axillary temperatures } \\
\text { were recorded in Bystrova } 2003 \text {. Results of the statistical tests for the SSC } \\
\text { group compared with the other groups were provided for } 2 / 8 \text { of the PCERA } \\
\text { composite variables, child disregulation and irritability and dyadic } \\
\text { mutuality and reciprocity. The results for the other composite variables }\end{array}$ \\
\hline
\end{tabular}

Cochrane Database Syst Rev. Author manuscript; available in PMC 2014 April 08. 
were not reported but were stated as insignificant (Bystrova 2009). Additional statistical data was obtained from the researchers

\begin{tabular}{ll}
\hline Other bias $\quad$ Unclear risk & $\begin{array}{l}\text { Data were reported using "per protocol" rather than "intention to treat" } \\
\text { analysis }\end{array}$ \\
\hline
\end{tabular}

Carfoot 2004

\begin{tabular}{|c|c|c|}
\hline Methods & \multicolumn{2}{|c|}{ Randomized controlled trial (sealed envelopes). } \\
\hline Participants & \multicolumn{2}{|c|}{26 healthy full term infants $>36$ weeks' gestation and their mothers } \\
\hline Interventions & \multicolumn{2}{|c|}{$\begin{array}{l}\text { 1) SSC group = mothers given infants to hold prone between their breasts and covered with a } \\
\text { warm blanket as soon as possible postbirth. Midwives assisted with the } 1 \text { st breastfeeding. 2) } \\
\text { Control group = babies dried, wrapped in a towel and handed to mom or dad. Midwives assisted } \\
\text { with the } 1 \text { st breastfeeding }\end{array}$} \\
\hline Outcomes & \multicolumn{2}{|c|}{$\begin{array}{l}\text { Success of the 1st breastfeeding (BAT score 8-12), type of feeding at } 4 \text { months postbirth } \\
\text { (exclusive breastfeeding, mixed feedings, artificial feedings) }\end{array}$} \\
\hline Notes & \multicolumn{2}{|c|}{ Study was done in Cheshire, UK. } \\
\hline \multicolumn{3}{|l|}{ Risk of bias } \\
\hline Bias & Authors' judgement & Support for judgement \\
\hline $\begin{array}{l}\text { Random sequence } \\
\text { generation } \\
\text { (selection bias) }\end{array}$ & Low risk & Computer-generated randomization list. \\
\hline $\begin{array}{l}\text { Allocation } \\
\text { concealment } \\
\text { (selection bias) }\end{array}$ & Unclear risk & $\begin{array}{l}\text { Sequence of sealed envelopes (not clear if opaque) and not clear whether } \\
\text { the envelopes were numbered and opened in sequence. }\end{array}$ \\
\hline $\begin{array}{l}\text { Blinding } \\
\text { (performance bias } \\
\text { and detection bias) } \\
\text { All outcomes }\end{array}$ & Unclear risk & $\begin{array}{l}\text { There was no blinding in this study. It is possible that the lack of } \\
\text { blinding may have affected women's responses and behavior, that } \\
\text { clinical care other than skin to skin contact may also have differed by } \\
\text { randomization groups and outcome assessors would be aware of } \\
\text { allocation during the first feed (observed) and this may have affected } \\
\text { their observations }\end{array}$ \\
\hline $\begin{array}{l}\text { Incomplete } \\
\text { outcome data } \\
\text { (attrition bias) All } \\
\text { outcomes }\end{array}$ & Unclear risk & $\begin{array}{l}\text { Pilot study including } 26 \text { mother infant pairs looking at study feasibility } \\
\text { (data on review outcomes not reported). }\end{array}$ \\
\hline $\begin{array}{l}\text { Selective reporting } \\
\text { (reporting bias) }\end{array}$ & Unclear risk & Assessment from published study report only. \\
\hline Other bias & Low risk & Other bias not apparent. \\
\hline
\end{tabular}

\section{Carfoot 2005}

\begin{tabular}{ll}
\hline Methods & $\begin{array}{l}\text { Randomized controlled trial (sequence of sealed envelopes containing next allocation from a } \\
\text { computer-generated randomization list) }\end{array}$ \\
\hline Participants & 204 healthy full term infants > 36 weeks' gestation and their mothers \\
\hline Interventions & $\begin{array}{l}\text { 1) SSC group = mothers given naked infants to hold prone between their breasts and covered with } \\
\text { a warm blanket as soon as possible postbirth. Midwives assisted with the 1st breastfeeding. } 2) \\
\text { Control group = babies dried, wrapped in a towel and handed to mom or dad. Midwives assisted } \\
\text { with the 1st breastfeeding }\end{array}$ \\
\hline Outcomes & $\begin{array}{l}\text { Success of the 1st breastfeeding (BAT score 8-12), success of a subsequent breastfeeding, mean } \\
\text { temperature 1 hour postbirth, maternal satisfaction with care, preference for same postdelivery } \\
\text { care in the future, type of feeding at } 4 \text { months (exclusive, partial breast, formula feeding) }\end{array}$ \\
\hline
\end{tabular}

Cochrane Database Syst Rev. Author manuscript; available in PMC 2014 April 08. 


\begin{tabular}{|c|c|c|}
\hline Notes & \multicolumn{2}{|c|}{ Study was done in Cheshire, UK. } \\
\hline \multicolumn{3}{|l|}{ Risk of bias } \\
\hline Bias & Authors' judgement & Support for judgement \\
\hline $\begin{array}{l}\text { Random } \\
\text { sequence } \\
\text { generation } \\
\text { (selection bias) }\end{array}$ & Low risk & Computer-generated randomization list. \\
\hline $\begin{array}{l}\text { Allocation } \\
\text { concealment } \\
\text { (selection bias) }\end{array}$ & Unclear risk & $\begin{array}{l}\text { Sequence of sealed envelopes (not clear if opaque) and not clear whether } \\
\text { the envelopes were numbered and opened in sequence. }\end{array}$ \\
\hline $\begin{array}{l}\text { Blinding } \\
\text { (performance bias } \\
\text { and detection } \\
\text { bias) } \\
\text { All outcomes }\end{array}$ & Unclear risk & $\begin{array}{l}\text { There was no blinding in this study. It is possible that the lack of blinding } \\
\text { may have affected women's responses and behavior, that clinical care } \\
\text { other than skin to skin contact may also have differed by randomization } \\
\text { groups and outcome assessors would be aware of allocation during the } \\
\text { first feed (observed) and this may have affected their observations }\end{array}$ \\
\hline $\begin{array}{l}\text { Incomplete } \\
\text { outcome data } \\
\text { (attrition bias) All } \\
\text { outcomes }\end{array}$ & Low risk & $\begin{array}{l}325 \text { women initially approached and } 244 \text { agreed to take part ( } 75 \% \text { ). } 204 \\
\text { women randomized data and } 197 \text { observed at } 1^{s t} \text { data collection point } \\
\text { (with analysis according to randomization group) and data available for } \\
197 \text { women at } 4 \text { month follow-up }\end{array}$ \\
\hline $\begin{array}{l}\text { Selective } \\
\text { reporting } \\
\text { (reporting bias) }\end{array}$ & Unclear risk & Assessment from published study report only. \\
\hline Other bias & Low risk & $\begin{array}{l}\text { Other bias not apparent. } \\
\text { Baseline characteristics appeared similar. }\end{array}$ \\
\hline
\end{tabular}

\section{Carlsson 1978}

\begin{tabular}{|c|c|c|}
\hline Methods & \multicolumn{2}{|c|}{ Randomized controlled trial. } \\
\hline Participants & \multicolumn{2}{|c|}{62 healthy, full term infants. The mothers were randomized into 1 of 3 groups before delivery } \\
\hline Interventions & \multicolumn{2}{|c|}{$\begin{array}{l}\text { 1) Extended contact-new routine group }=\text { kept their naked infants for } 1 \text { hour immediately postbirth, } \\
\text { mothers cared for infants. } 2 \text { ) Extended contact-old routine }=\text { kept their naked infants immediately } \\
\text { postbirth for } 1 \text { hour, staff cared for infants. } 3 \text { ) Limited contact-old routine group = held their } \\
\text { infants for } 5 \text { min immediately postbirth, staff cared for infants }\end{array}$} \\
\hline Outcomes & \multicolumn{2}{|c|}{$\begin{array}{l}\text { Observation of maternal behavior (contact behavior and behavior not implying contact with baby) } \\
\text { by videotape during breastfeeding on day } 2 \text { and } 4 \text { postbirth }\end{array}$} \\
\hline Notes & \multicolumn{2}{|c|}{ Study was done with middle-income primipara in Sweden. } \\
\hline \multicolumn{3}{|l|}{ Risk of bias } \\
\hline Bias & Authors' judgement & Support for judgement \\
\hline $\begin{array}{l}\text { Random } \\
\text { sequence } \\
\text { generation } \\
\text { (selection bias) }\end{array}$ & Unclear risk & $\begin{array}{l}\text { Method used to generate the randomization sequence were not described. } \\
\text { The study involved "randomly selected" women who were "randomly } \\
\text { assigned" to } 1 \text { of the } 3 \text { study groups }\end{array}$ \\
\hline $\begin{array}{l}\text { Allocation } \\
\text { concealment } \\
\text { (selection bias) }\end{array}$ & Unclear risk & $\begin{array}{l}\text { The method used to conceal group allocation at the point of } \\
\text { randomization was not described. }\end{array}$ \\
\hline $\begin{array}{l}\text { Blinding } \\
\text { (performance } \\
\text { bias and } \\
\text { detection bias) } \\
\text { All outcomes }\end{array}$ & Unclear risk & $\begin{array}{l}\text { It was stated that participants "were unaware of the purposes of the } \\
\text { study". However, presumably women would be aware that they were } \\
\text { being observed when they were feeding their babies. Clinical staff caring } \\
\text { for women may have been aware of early contact and it was not clear } \\
\text { whether the staff carrying out observations were aware of group } \\
\text { allocation }\end{array}$ \\
\hline $\begin{array}{l}\text { Incomplete } \\
\text { outcome data }\end{array}$ & Unclear risk & $\begin{array}{l}62 \text { women were randomized. } 50 \text { were available for follow up }(81 \%) \text { and } \\
\text { full observational data were available for } 46(74 \%) \text {. Loss appeared to be } \\
\text { reasonably balanced across groups. }\end{array}$ \\
\hline
\end{tabular}

Cochrane Database Syst Rev. Author manuscript; available in PMC 2014 April 08. 
(attrition bias) All outcomes

\begin{tabular}{lll}
\hline $\begin{array}{l}\text { Selective } \\
\text { reporting } \\
\text { (reporting bias) }\end{array}$ & Unclear risk & $\begin{array}{l}\text { Although observation methods were described it is not clear what the } \\
\text { main study outcome means (frequency of mother/infant contact/not } \\
\text { contact during breast or bottle feeding). The frequencies were presented } \\
\text { as means with SEs. The average number of observation points during a } \\
\text { feed would be approximately 100, but the mean figures are closer to } 200 \\
\text { so it seems more than 1 behavior was noted in each observation period. } \\
\text { However, it was stated that if the same behavior (which may have been a } \\
\text { contact behavior) occurred more than once in any observation period it } \\
\text { was only recorded once. It is possible therefore that continuous high } \\
\text { contact behavior was rated as being of lower contact value than rapidly } \\
\text { changing behaviors } \\
\text { Several results were not presented according to randomization group and } \\
\text { results were difficult to interpret. }\end{array}$ \\
& $\begin{array}{l}\text { Baseline imbalance not apparent. } \\
\text { Other: Results were difficult to interpret and } 2 \text { groups that received } \\
\text { different treatments were merged for some results but not others }\end{array}$ \\
\hline Other bias &
\end{tabular}

Christensson 1992

\begin{tabular}{|c|c|c|}
\hline Methods & \multicolumn{2}{|c|}{ Randomized controlled trial. } \\
\hline Participants & \multicolumn{2}{|c|}{50 full term infants and their mothers randomized after the delivery } \\
\hline Interventions & \multicolumn{2}{|c|}{ a) $80 \mathrm{~min}$ of SSC with the mother, b) $80 \mathrm{~min}$ in a cot. } \\
\hline Outcomes & \multicolumn{2}{|c|}{$\begin{array}{l}\text { Axillary, thigh, and interscapular temperatures. Duration of crying. Blood glucose, base excess, } \\
\text { respiratory rate, HR after } 90 \mathrm{~min}\end{array}$} \\
\hline Notes & \multicolumn{2}{|c|}{ Study was done in Madrid, Spain. } \\
\hline \multicolumn{3}{|l|}{ Risk of bias } \\
\hline Bias & Authors' judgement & Support for judgement \\
\hline $\begin{array}{l}\text { Random sequence } \\
\text { generation } \\
\text { (selection bias) }\end{array}$ & Unclear risk & Methods to generate the allocation sequence were not described. \\
\hline $\begin{array}{l}\text { Allocation } \\
\text { concealment } \\
\text { (selection bias) }\end{array}$ & Unclear risk & $\begin{array}{l}\text { Very little information on study methods. Described as "allocated } \\
\text { randomly" }\end{array}$ \\
\hline $\begin{array}{l}\text { Blinding } \\
\text { (performance bias } \\
\text { and detection bias) } \\
\text { All outcomes }\end{array}$ & Unclear risk & $\begin{array}{l}\text { Women would be aware of group allocation. It is not likely that this } \\
\text { affected outcomes such as temperature but it may have affected baby } \\
\text { behavior (it appeared that mothers in the cot group were advised not to } \\
\text { pick their babies up even if the baby was crying) } \\
\text { Clinical staff and observers were not blind to group allocation. It is } \\
\text { difficult to know whether this had any effect on temperature recording. } \\
\text { The observation of crying may have been affected by knowledge of } \\
\text { group allocation }\end{array}$ \\
\hline $\begin{array}{l}\text { Incomplete } \\
\text { outcome data } \\
\text { (attrition bias) All } \\
\text { outcomes }\end{array}$ & Low risk & $\begin{array}{l}\text { It appeared that all women randomized were followed up, } \\
\text { randomization seemed to occur before delivery and it appeared that no } \\
\text { women were excluded following randomization (as they became } \\
\text { ineligible due to complications in labor, etc) }\end{array}$ \\
\hline $\begin{array}{l}\text { Selective reporting } \\
\text { (reporting bias) }\end{array}$ & Unclear risk & $\begin{array}{l}\text { Difficult to assess without access to study protocol. Multiple } \\
\text { observation points means that results for temperature are difficult to } \\
\text { interpret. Results for crying are also difficult to interpret as mothers in } \\
\text { the cot group were discouraged from picking up their babies during the } \\
\text { observation period even if they were crying. }\end{array}$ \\
\hline Other bias & Unclear risk & $\begin{array}{l}\text { No power calculations reported. } \\
\text { Baseline characteristics in the } 2 \text { groups appeared similar. Very little } \\
\text { information was provided on study methods }\end{array}$ \\
\hline
\end{tabular}

\section{Christensson 1995}

Cochrane Database Syst Rev. Author manuscript; available in PMC 2014 April 08. 


\begin{tabular}{|c|c|c|}
\hline Methods & \multicolumn{2}{|c|}{ Randomized controlled trial. } \\
\hline Participants & \multicolumn{2}{|c|}{44 full term infants and their mothers immediately postbirth } \\
\hline Interventions & \multicolumn{2}{|c|}{$\begin{array}{l}\text { Group a) } 76-85 \mathrm{~min} \text { of SSC with the mother, b) infant in a cot for } 76-85 \mathrm{~min} \text {, c) infant in a cot } \\
\text { for } 35 \mathrm{~min} \text { then SSC for } 45 \mathrm{~min}\end{array}$} \\
\hline Outcomes & \multicolumn{2}{|c|}{ Duration of crying, axillary temperature $90 \mathrm{~min}$ postbirth. } \\
\hline Notes & \multicolumn{2}{|c|}{ Study was done in Madrid, Spain. } \\
\hline \multicolumn{3}{|l|}{ Risk of bias } \\
\hline Bias & Authors' judgement & Support for judgement \\
\hline $\begin{array}{l}\text { Random sequence } \\
\text { generation (selection } \\
\text { bias) }\end{array}$ & Unclear risk & Not described "allocated randomly". \\
\hline $\begin{array}{l}\text { Allocation } \\
\text { concealment } \\
\text { (selection bias) }\end{array}$ & Unclear risk & $\begin{array}{l}\text { Not described (allocation was before delivery but women and staff } \\
\text { were not informed of the allocation until after delivery) }\end{array}$ \\
\hline $\begin{array}{l}\text { Blinding } \\
\text { (performance bias } \\
\text { and detection bias) } \\
\text { All outcomes }\end{array}$ & Unclear risk & $\begin{array}{l}\text { Participants and staff were not blinded. It is not clear whether } \\
\text { knowledge of allocation would have affected maternal behavior and } \\
\text { responses (for those in the "cot" group, women were asked not to } \\
\text { move the baby). Staff providing care may have altered other aspects of } \\
\text { care. Outcome assessors were blinded (blind assessment of audiotapes } \\
\text { - although presumably they would also hear the mother and other noise } \\
\text { so may have been able to ascertain group assignment) }\end{array}$ \\
\hline $\begin{array}{l}\text { Incomplete outcome } \\
\text { data (attrition bias) } \\
\text { All outcomes }\end{array}$ & Unclear risk & $\begin{array}{l}\text { Due to mechanical failures there were missing data for the primary } \\
\text { outcome. } 44 \text { women were randomized and audiotape data were } \\
\text { available for } 33(75 \%)\end{array}$ \\
\hline $\begin{array}{l}\text { Selective reporting } \\
\text { (reporting bias) }\end{array}$ & Unclear risk & Assessed from published study report. \\
\hline Other bias & Unclear risk & $\begin{array}{l}\text { Describe any baseline in balance: Not apparent, but sample size was } \\
\text { small so imbalances between groups although not statistically } \\
\text { significant may have been important (e.g. cot group } 7 / 14 \text { primips, s to } \\
\text { s } 5 / 15 \text { primips) }\end{array}$ \\
\hline
\end{tabular}

\section{Chwo 1999}

\begin{tabular}{|c|c|c|}
\hline Methods & \multicolumn{2}{|c|}{ Randomized controlled trial (computerized minimization technique) } \\
\hline Participants & \multicolumn{2}{|c|}{34 healthy late preterm infants $34-36$ weeks' gestation and their mothers } \\
\hline Interventions & \multicolumn{2}{|c|}{$\begin{array}{l}\text { 1) SSC group }=\mathrm{SSC} \text { and on cue self-regulatory feedings during } 61 \text {-hour feeding periods } \\
\text { beginning } \mathrm{M}=21 \text { hours postbirth. The infant, in a small diaper, was placed on the ventral surface } \\
\text { of their mother's torso. } 2 \text { ) Control group = infants held wrapped in blankets during } 61 \text {-hour } \\
\text { feeding periods beginning } \mathrm{M}=23 \text { hours postbirth }\end{array}$} \\
\hline Outcomes & \multicolumn{2}{|c|}{$\begin{array}{l}\text { Infant body weight change day } 14 \text { and } 28 \text { postbirth, length of stay in the hospital, tympanic } \\
\text { temperature change and variability, behavioral state inactive awake, drowsy, crying during } \\
\text { feedings }\end{array}$} \\
\hline Notes & \multicolumn{2}{|c|}{ Study was done in a teaching hospital near Taipei, Taiwan. } \\
\hline \multicolumn{3}{|l|}{ Risk of bias } \\
\hline Bias & Authors' judgement & Support for judgement \\
\hline $\begin{array}{l}\text { Random sequence } \\
\text { generation } \\
\text { (selection bias) }\end{array}$ & Low risk & $\begin{array}{l}\text { Computer-generated minimization process with stratification for gender, } \\
\text { birthweight, mode of delivery and parity }\end{array}$ \\
\hline
\end{tabular}

Cochrane Database Syst Rev. Author manuscript; available in PMC 2014 April 08. 


\begin{tabular}{|c|c|c|}
\hline $\begin{array}{l}\text { Allocation } \\
\text { concealment } \\
\text { (selection bias) }\end{array}$ & Low risk & $\begin{array}{l}\text { Computerised allocation. Not clear how the process was carried out at } \\
\text { the point of group allocation }\end{array}$ \\
\hline $\begin{array}{l}\text { Blinding } \\
\text { (performance bias } \\
\text { and detection bias) } \\
\text { All outcomes }\end{array}$ & High risk & $\begin{array}{l}\text { Women in both the control and intervention did not receive usual care } \\
\text { and would likely to have been aware of group assignment. Staff } \\
\text { providing care and breastfeeding advice also collected outcome data. } \\
\text { This may have had an impact on some outcomes - particularly the } \\
\text { observation of infant behavior }\end{array}$ \\
\hline $\begin{array}{l}\text { Incomplete } \\
\text { outcome data } \\
\text { (attrition bias) All } \\
\text { outcomes }\end{array}$ & Unclear risk & $\begin{array}{l}34 \text { women followed up in hospital by day } 1423 \text { infants available to } \\
\text { follow up and } 26 \text { on day } 28\end{array}$ \\
\hline $\begin{array}{l}\text { Selective reporting } \\
\text { (reporting bias) }\end{array}$ & Unclear risk & Assessment carried out using published study report only. \\
\hline Other bias & Unclear risk & $\begin{array}{l}\text { The intervention may not be generalizable to other babies in the same } \\
\text { study setting. The intervention was described as KC but infants were not } \\
\text { in SSC until } 4 \text { hours after the birth, then contact was for } 1 \text { hour at } 4- \\
\text { hourly intervals at specified feeding times for } 6 \text { feeds. Control infants } \\
\text { were offered the same contact but babies were in blankets, both groups } \\
\text { were given advice and support from the observer. It was not clear how } \\
\text { much time infants spent feeding during the observation period } \\
\text { Groups were reported to be similar at baseline. }\end{array}$ \\
\hline
\end{tabular}

\section{Craig 1982}

\begin{tabular}{|c|c|c|}
\hline Methods & \multicolumn{2}{|c|}{$\begin{array}{l}\text { Randomized controlled trial (sealed envelopes prepared using a table of random numbers by } \\
\text { gender) }\end{array}$} \\
\hline Participants & \multicolumn{2}{|c|}{60 healthy full term infants and their mothers. } \\
\hline Interventions & \multicolumn{2}{|c|}{$\begin{array}{l}\text { 1) Control group }=\text { mothers held their wrapped infants for } 3 \text { min then contact at feedings every } 4 \\
\text { hours. 2) Early SSC group = infants were placed in SSC on their mother's chests for } 54 \text { min then } \\
\text { contact at feedings every } 4 \text { hours }\end{array}$} \\
\hline Outcomes & \multicolumn{2}{|c|}{$\begin{array}{l}\text { 1) Neonatal Perception Inventory. 2) Interview of mother's experiences during pregnancy, } \\
\text { delivery, 1st postpartum month. 3) Questions about infant behavior during a home visit at } 1 \\
\text { month postbirth }\end{array}$} \\
\hline Notes & \multicolumn{2}{|c|}{ Study was done with low-income primapara in the USA. } \\
\hline \multicolumn{3}{|l|}{ Risk of bias } \\
\hline Bias & Authors' judgement & Support for judgement \\
\hline $\begin{array}{l}\text { Random sequence } \\
\text { generation } \\
\text { (selection bias) }\end{array}$ & Low risk & Table of random numbers. \\
\hline $\begin{array}{l}\text { Allocation } \\
\text { concealment } \\
\text { (selection bias) }\end{array}$ & Unclear risk & $\begin{array}{l}\text { "sealed envelopes" (not clear if opaque and used in sequential order or if } \\
\text { any envelopes were discarded) "Separate envelopes were prepared for } \\
\text { male and female infants to insure a comparable sex distribution in each } \\
\text { contact group" }\end{array}$ \\
\hline $\begin{array}{l}\text { Blinding } \\
\text { (performance bias } \\
\text { and detection bias) } \\
\text { All outcomes }\end{array}$ & Unclear risk & $\begin{array}{l}\text { "Mothers given extra contact were not aware that their care differed } \\
\text { from that given to other patients". "Patients were told that the } \\
\text { investigators wished to study maternal-infant relationships during the } \\
\text { first postpartum month." } \\
\text { Staff caring for women would be aware of group assignment during the } \\
\text { early postpartum period. The principal investigator recruited mothers } \\
\text { and collected most of the outcome data. An attempt was made to check } \\
\text { whether the data collected by this investigator and another researcher; } \\
\text { there was no evidence of bias. }\end{array}$ \\
\hline $\begin{array}{l}\text { Incomplete } \\
\text { outcome data } \\
\text { (attrition bias) All } \\
\text { outcomes }\end{array}$ & High risk & $\begin{array}{l}\text { There was serious attrition and missing data at some data collection } \\
\text { points. } 60 \text { women were recruited; outcome data at } 1 \text { month were } \\
\text { available for } 49(81.7 \%) \text {. Loss was reported to be balanced between } \\
\text { groups. } 24 \text { of the sample }(40 \%) \text { completed a behavioral record. }\end{array}$ \\
\hline
\end{tabular}

Cochrane Database Syst Rev. Author manuscript; available in PMC 2014 April 08. 


\begin{tabular}{lll}
$\begin{array}{l}\text { Selective reporting } \\
\text { (reporting bias) }\end{array}$ & Unclear risk & $\begin{array}{l}\text { Data reported as in introduction, but not clear if other data collected. } \\
\text { (Assessment from published paper only.) }\end{array}$ \\
\hline Other bias & Unclear risk & $\begin{array}{l}\text { Baseline imbalance not apparent. } \\
\text { Some results were difficult to interpret. It appeared that mean scores had } \\
\text { been calculated from a 4-point category measure }\end{array}$ \\
\hline
\end{tabular}

\section{Curry 1982}

\begin{tabular}{|c|c|c|}
\hline Methods & \multicolumn{2}{|c|}{ Randomized controlled trial (sealed envelopes). } \\
\hline Participants & \multicolumn{2}{|c|}{20 healthy full term infants randomized during the first hour postbirth } \\
\hline Interventions & \multicolumn{2}{|c|}{$\begin{array}{l}\text { 1) Control group = held their wrapped infants for } 36 \text { min during the first hour postbirth. 2) SSC } \\
\text { group = held their infants in SSC for } 35 \text { min during the first hour postbirth. Both groups had } 12 \\
\text { hours of rooming-in during the day }\end{array}$} \\
\hline Outcomes & \multicolumn{2}{|c|}{$\begin{array}{l}\text { 1) } 7 \text { maternal attachment behaviors (en face, kiss, hold, encompass, close contact and smile at) } \\
\text { measured at } 36 \text { hours and } 3 \text { months postbirth during breastfeeding. 2) The Tennessee Self } \\
\text { Concept measured at } 2 \text { months postbirth }\end{array}$} \\
\hline Notes & \multicolumn{2}{|c|}{$\begin{array}{l}\text { Study was done with well-educated, married, middle-income, Caucasian, breastfeeding primipara } \\
\text { in the USA }\end{array}$} \\
\hline \multicolumn{3}{|l|}{ Risk of bias } \\
\hline Bias & Authors' judgement & Support for judgement \\
\hline $\begin{array}{l}\text { Random sequence } \\
\text { generation } \\
\text { (selection bias) }\end{array}$ & Unclear risk & $\begin{array}{l}\text { In batches of } 10,5 \text { envelopes each contained control or intervention } \\
\text { allocations }\end{array}$ \\
\hline $\begin{array}{l}\text { Allocation } \\
\text { concealment } \\
\text { (selection bias) }\end{array}$ & Unclear risk & $\begin{array}{l}\text { Dark brown envelopes containing allocations were shuffled and an } \\
\text { envelope selected. When } 10 \text { envelopes had been used a further } 10 \text { were } \\
\text { prepared, then } 1 \text { of each allocation for last } 2 \text { random assignments }\end{array}$ \\
\hline $\begin{array}{l}\text { Blinding } \\
\text { (performance bias } \\
\text { and detection bias) } \\
\text { All outcomes }\end{array}$ & Unclear risk & $\begin{array}{l}\text { It was stated that mothers were not told the precise reasons for the study, } \\
\text { although mothers would be aware of the intervention. The staff taking } \\
\text { infant temperatures during the intervention period would be aware of } \\
\text { allocation. It was stated that the investigators collecting outcome data at } \\
36 \text { hours and at } 3 \text { months was not aware of group, although mothers may } \\
\text { have revealed this during interviews }\end{array}$ \\
\hline $\begin{array}{l}\text { Incomplete } \\
\text { outcome data } \\
\text { (attrition bias) All } \\
\text { outcomes }\end{array}$ & Unclear risk & $\begin{array}{l}56 \text { women were recruited, but at the point of randomization only } 20 \\
\text { women remained. Only women delivering while the researcher was on } \\
\text { the premises were included. Not clear exactly when randomization } \\
\text { occurred }\end{array}$ \\
\hline $\begin{array}{l}\text { Selective } \\
\text { reporting } \\
\text { (reporting bias) }\end{array}$ & Unclear risk & $\begin{array}{l}\text { Used observation as main outcome which is difficult to interpret. Results } \\
\text { reported as mean occurrence of attachment behaviors, it is not clear } \\
\text { whether the same mother could exhibit lots of behaviors. Mean number } \\
\text { of behaviors during the same length of observation period appeared } \\
\text { considerably less at } 3 \text { months follow-up compared with } 36 \text { hrs. }\end{array}$ \\
\hline Other bias & Unclear risk & $\begin{array}{l}\text { Baseline imbalance not clear, small sample size. } \\
\text { Less than half of the eligible sample was recruited. }\end{array}$ \\
\hline
\end{tabular}

De Chateau 1977

\begin{tabular}{ll}
\hline Methods & Randomized controlled trial (open random numbers table). \\
\hline Participants & 62 healthy full term infants and their mothers. Group 1 primiparous mothers and their infants $\mathrm{n}=$ \\
& $\begin{array}{l}\text { 22. Group } 2 \text { primiparous mothers and their infants } \mathrm{n}=20 . \text { Group } 3 \text { multiparous mothers and their } \\
\text { infants } \mathrm{n}=20\end{array}$ \\
\hline
\end{tabular}

Cochrane Database Syst Rev. Author manuscript; available in PMC 2014 April 08. 
Group 1: 15-20 min of SSC during the first hour postbirth. The infants were placed on the breast at 10 min postbirth and assisted by the midwives with breastfeeding. Groups 2 and $3=$ routine care. The dressed babies were placed in a crib at the mother's bedside or in her bed at $10 \mathrm{~min}$ postbirth

\begin{tabular}{|c|c|c|}
\hline Outcomes & \multicolumn{2}{|c|}{$\begin{array}{l}\text { Observation of mother's behavior during breastfeeding at } 36 \text { hours postbirth. Mother's and infant's } \\
\text { behavior at } 3 \text { months during free play. } \\
\text { Breastfeeding at } 3 \text { months, } 1 \text { year postbirth. Mother's and infant's behavior during a physical exam } \\
\text { and infant development at } 12 \text { months }\end{array}$} \\
\hline Notes & \multicolumn{2}{|c|}{$\begin{array}{l}\text { Study was done with middle-income women in Sweden. 2-arm trial with individual randomization } \\
\text { (a } 3^{r d} \text { group of women (multips) were also included as a comparison group in } 1 \text { of the reports but } \\
\text { this group was not randomly allocated and is not included in the analyses) }\end{array}$} \\
\hline \multicolumn{3}{|l|}{ Risk of bias } \\
\hline Bias & Authors' judgement & Support for judgement \\
\hline $\begin{array}{l}\text { Random } \\
\text { sequence } \\
\text { generation } \\
\text { (selection bias) }\end{array}$ & High risk & $\begin{array}{l}\text { "Immediately after delivery, the midwife or auxiliary compared the } \\
\text { number on the mother's record with a coincidence table... placed in an } \\
\text { office outside the delivery room - the primiparous mothers were randomly } \\
\text { assigned" }\end{array}$ \\
\hline $\begin{array}{l}\text { Allocation } \\
\text { concealment } \\
\text { (selection bias) }\end{array}$ & High risk & Allocation according to open list after delivery. \\
\hline $\begin{array}{l}\text { Blinding } \\
\text { (performance } \\
\text { bias and } \\
\text { detection bias) } \\
\text { All outcomes }\end{array}$ & Unclear risk & $\begin{array}{l}\text { It appeared that women were not aware that the intervention was part of a } \\
\text { study, they were told that the observation was to examine mother infant } \\
\text { behavior during breastfeeding. Staff providing care would be aware of the } \\
\text { allocation. It was stated that observation was carried out by staff who "did } \\
\text { not know to which group the mother-infant pairs belonged". It was not } \\
\text { clear whether other data were collected by blind observers }\end{array}$ \\
\hline $\begin{array}{l}\text { Incomplete } \\
\text { outcome data } \\
\text { (attrition bias) } \\
\text { All outcomes }\end{array}$ & Unclear risk & $\begin{array}{l}42 \text { women were randomized. } 1 \text { woman from the intervention group was } \\
\text { not observed at } 36 \text { hours. At } 1 \text { year follow up there were } 33 \text { remaining; of } \\
\text { the } 9 \text { lost to follow up, } 5 \text { were described as belonging to the "lowest } \\
\text { socioeconomic category". There were some further missing data }\end{array}$ \\
\hline $\begin{array}{l}\text { Selective } \\
\text { reporting } \\
\text { (reporting bias) }\end{array}$ & Unclear risk & $\begin{array}{l}\text { Data collected by observation difficult to interpret. It appeared that } \\
\text { women could contribute different numbers of observations to mean } \\
\text { scores. }\end{array}$ \\
\hline Other bias & Unclear risk & $\begin{array}{l}\text { No baseline imbalance apparent. } \\
\text { There was some discrepancy between results in the text and tables in } 1 \text { of } \\
\text { the papers. Denominators for some outcomes were not clear }\end{array}$ \\
\hline
\end{tabular}

\section{Fardig 1980}

\begin{tabular}{|c|c|c|}
\hline Methods & \multicolumn{2}{|c|}{ Randomized controlled trial (blind drawing of 1 of 3 numbers with replacement) } \\
\hline Participants & \multicolumn{2}{|c|}{$\begin{array}{l}51 \text { uncomplicated infants with gestation } 38-42 \text { weeks, birthweight of at least } 2500 \mathrm{~g} \text {, normal labor } \\
\text { and delivery and normal Apgar score }\end{array}$} \\
\hline Interventions & \multicolumn{2}{|c|}{$\begin{array}{l}\text { Group } 1 \text { infants were suctioned, dried under a radiant heater for } 5 \text { min and then placed naked on } \\
\text { the mother's bare chest for } 25 \text { min. The infant's back was then covered with } 2 \text { cotton blankets. } \\
\text { Group } 2 \text { infants were placed naked directly on the mother's chest for } 28 \text { min after the umbilical } \\
\text { cord was cut. Group } 3 \text { infants were placed under a radiant warmer without being placed on the } \\
\text { mother's chest }\end{array}$} \\
\hline Outcomes & \multicolumn{2}{|c|}{$\begin{array}{l}\text { Skin temperature measured on the infant's left side every } 3 \mathrm{~min} \text { for } 45 \mathrm{~min} \text {. Rectal temperature at } \\
21 \text { and } 45 \mathrm{~min} \text {. Outcomes were the number of infants with skin or rectal temperature in the neutral } \\
\text { range at } 21 \text { or } 45 \mathrm{~min}\end{array}$} \\
\hline Notes & \multicolumn{2}{|c|}{ Study was done in the USA. } \\
\hline \multicolumn{3}{|l|}{ Risk of bias } \\
\hline Bias & Authors' judgement & Support for judgement \\
\hline $\begin{array}{l}\text { Random sequence } \\
\text { generation } \\
\text { (selection bias) }\end{array}$ & Unclear risk & Drawing numbers. \\
\hline
\end{tabular}

Cochrane Database Syst Rev. Author manuscript; available in PMC 2014 April 08. 


\begin{tabular}{|c|c|c|}
\hline $\begin{array}{l}\text { Allocation } \\
\text { concealment } \\
\text { (selection bias) }\end{array}$ & Unclear risk & $\begin{array}{l}\text { Women were "randomly assigned to either the control group or to } 1 \text { of } \\
\text { the experimental groups by blind drawing of } 1 \text { of } 3 \text { numbers, with } \\
\text { replacement." This suggests that group allocation could be changed by } \\
\text { the investigator }\end{array}$ \\
\hline $\begin{array}{l}\text { Blinding } \\
\text { (performance bias } \\
\text { and detection } \\
\text { bias) } \\
\text { All outcomes }\end{array}$ & High risk & $\begin{array}{l}\text { "Both the couple and their caregiver were told how the baby would be } \\
\text { handled after delivery." Researcher collecting outcome data would also } \\
\text { be aware of group assignment }\end{array}$ \\
\hline $\begin{array}{l}\text { Incomplete } \\
\text { outcome data } \\
\text { (attrition bias) All } \\
\text { outcomes }\end{array}$ & Low risk & $\begin{array}{l}\text { Describe any loss of participants to follow-up at each data collection } \\
\text { point: It appeared that all women were accounted for at each data } \\
\text { collection point. It was not clear if there was any missing data }\end{array}$ \\
\hline $\begin{array}{l}\text { Selective } \\
\text { reporting } \\
\text { (reporting bias) }\end{array}$ & Unclear risk & Most outcomes appear to have been reported \\
\hline Other bias & Unclear risk & $\begin{array}{l}\text { Authors reported that there were no significant differences between } \\
\text { groups for a number of variables but the data were not shown. It was not } \\
\text { clear how many of those eligible were approached to take part or whether } \\
\text { recruitment only occurred at particular times (e.g. was the same } \\
\text { researcher available at night and weekend) nor whether women who had } \\
\text { long labors remained in the study. It is not clear whether women were } \\
\text { excluded postrandomization if there was any intrapartum problem }\end{array}$ \\
\hline
\end{tabular}

\section{Ferber 2004}

\begin{tabular}{|c|c|c|}
\hline Methods & \multicolumn{2}{|c|}{ Randomized controlled trial (table of random numbers). } \\
\hline Participants & \multicolumn{2}{|c|}{42 healthy full term infants $38-42$ weeks' gestation and their mothers } \\
\hline Interventions & \multicolumn{2}{|c|}{$\begin{array}{l}\text { All newborns were placed on mother's chest for 5-10 min, then dried, weighed and dressed. 1) SSC } \\
\text { group = infants brought back to mom } 15-20 \text { min postbirth, undressed, placed SSC between the } \\
\text { mother's breasts and covered with blankets for } 60 \mathrm{~min} \text {. Then the infants were taken to the newborn } \\
\text { nursery for } 4 \text { hours of observation. 2) Control infants were taken to the newborn nursery, placed } \\
\text { under a warmer for 5-10 min, swaddled and laid in a bassinet. They were brought back to their } \\
\text { mothers at } 5 \text { hours postbirth }\end{array}$} \\
\hline Outcomes & \multicolumn{2}{|c|}{$\begin{array}{l}\text { Optimal respirations, motor disorganization, visceral stress response, optimal flexed movements, } \\
\text { extension movements, facial movements, sleep state, drowsy, fussy and crying states, positive } \\
\text { attention signs, negative attention signs }\end{array}$} \\
\hline Notes & \multicolumn{2}{|c|}{$\begin{array}{l}\text { Study was done in Haifa, Israel with primarily middle- to upper-middle class European, African } \\
\text { and Arab mothers }\end{array}$} \\
\hline \multicolumn{3}{|l|}{ Risk of bias } \\
\hline Bias & Authors' judgement & Support for judgement \\
\hline $\begin{array}{l}\text { Random } \\
\text { sequence } \\
\text { generation } \\
\text { (selection bias) }\end{array}$ & Low risk & $\begin{array}{l}\text { Random number tables, the sequence was generated by a different person } \\
\text { from the } 1 \text { carrying out recruitment and group assignment }\end{array}$ \\
\hline $\begin{array}{l}\text { Allocation } \\
\text { concealment } \\
\text { (selection bias) }\end{array}$ & Unclear risk & Not described. \\
\hline $\begin{array}{l}\text { Blinding } \\
\text { (performance } \\
\text { bias and } \\
\text { detection bias) } \\
\text { All outcomes }\end{array}$ & Unclear risk & $\begin{array}{l}\text { It was stated that mothers were not aware of group assignment as mothers } \\
\text { in each group were kept separate (it was not clear how the study was } \\
\text { described to mothers or how consent was obtained). Those staff caring for } \\
\text { mothers after the birth would be aware of group assignment and other } \\
\text { aspects of care may have differed. It was stated that staff in the newborn } \\
\text { nursery (where outcomes were assessed) were blind to group assignment } \\
\text { but it was not clear how effective this blinding would be as babies in the } \\
\text { control and intervention arms were admitted at different times after birth } \\
\text { (and this would be stated on notes). It was stated that outcome assessment } \\
\text { was done by blind observers, it was not clear whether attempted blinding } \\
\text { was successful }\end{array}$ \\
\hline
\end{tabular}




\begin{tabular}{lll}
$\begin{array}{l}\text { Incomplete } \\
\text { outcome data } \\
\text { (attrition bias) } \\
\text { All outcomes }\end{array}$ & Low risk & $\begin{array}{l}\text { Randomization was carried out at the start of labor. 50 women were } \\
\text { randomized and there were } 3 \text { postrandomization exclusions from the } \\
\text { control group as women became ineligible. It was not clear whether there } \\
\text { were any missing data }\end{array}$ \\
\hline $\begin{array}{l}\text { Selective } \\
\text { reporting } \\
\text { (reporting bias) }\end{array}$ & Unclear risk & Assessment from published report. \\
\hline Other bias & Unclear risk & $\begin{array}{l}\text { No significant differences between groups at baseline on the variables } \\
\text { measured, although there were a greater proportion of female children in } \\
\text { the control group (63\% vs 48\%) (it is not clear whether this would be } \\
\text { likely to be associated with any between group differences) } \\
\text { Other: it was not clear whether possible confounding factors were taken } \\
\text { into account. The main outcome was infant sleep and movement. This is } \\
\text { likely to have been affected by the use of systemic opioid analgesia during } \\
\text { labor . It was not clear whether any women had received opioids. }\end{array}$ \\
\hline
\end{tabular}

Gouchon 2010

\begin{tabular}{|c|c|c|}
\hline Methods & \multicolumn{2}{|c|}{$\begin{array}{l}\text { Randomized controlled trial (a computer-generated a randomization list). Mothers were } \\
\text { randomized using opaque, sealed envelopes containing the group allocation }\end{array}$} \\
\hline Participants & \multicolumn{2}{|c|}{$\begin{array}{l}34 \text { Italian women scheduled for elective cesarean delivery using locoregional anesthesia recruited } \\
\text { from the maternity ward of Pinerolo Hospital, Turin, Italy and their healthy full term infants }\end{array}$} \\
\hline Interventions & \multicolumn{2}{|c|}{$\begin{array}{l}\text { Both groups: physical assessment, Apgar score, infants dried, wrapped in towel, handed to mother } \\
\text { for brief contact and transported to neonatal ward in an incubator for inspection, bath, weight. } \\
\text { Mother to OB ward } \\
\text { Control: baby dressed, taken to mother's room, mother instructed on how to breastfeed but she } \\
\text { could choose whether she wanted to breastfeed or not. Mom could keep baby in her bed, in a crib } \\
\text { or in the nursery during the 2-hour observation period } \\
\text { SSC: same treatment as control, but not dressed; fitted with disposable diaper, cap and wrapped in } \\
\text { a warm cloth; placed on mother's skin between breasts, left covered with cloth, bed sheet, and } \\
\text { blanket for approximately } 2 \text { hours. Mother instructed about how to breastfeed } \\
\text { Mean duration of SSC was } 82.9+45.9 \text { min. }\end{array}$} \\
\hline Outcomes & \multicolumn{2}{|c|}{$\begin{array}{l}\text { Newborn skin temperature using an infrared ray thermometer on the forehead, effectiveness of the } \\
\text { first breastfeeding, min postbirth of the first breastfeeding, exclusive or prevalent breastfeeding at } \\
\text { hospital discharge and at } 3 \text { months postbirth, infant crying and maternal satisfaction with SSC }\end{array}$} \\
\hline \multicolumn{3}{|l|}{ Notes } \\
\hline \multicolumn{3}{|l|}{ Risk of bias } \\
\hline Bias & Authors' judgement & Support for judgement \\
\hline $\begin{array}{l}\text { Random } \\
\text { sequence } \\
\text { generation } \\
\text { (selection bias) }\end{array}$ & Low risk & $\begin{array}{l}\text { States mothers were randomized using a computer-generated } \\
\text { randomization list }\end{array}$ \\
\hline $\begin{array}{l}\text { Allocation } \\
\text { concealment } \\
\text { (selection bias) }\end{array}$ & Low risk & $\begin{array}{l}\text { States opaque, sealed envelopes containing the next allocation were used. } \\
\text { The mothers were recruited prenatally, the envelopes were opened by the } \\
\text { nurse on the day of surgery }\end{array}$ \\
\hline $\begin{array}{l}\text { Blinding } \\
\text { (performance } \\
\text { bias and } \\
\text { detection bias) } \\
\text { All outcomes }\end{array}$ & Unclear risk & $\begin{array}{l}\text { No information provided. } \\
\text { IBFAT scores and infant temperatures were obtained while the infants } \\
\text { were held either SSC or dressed so the outcome assessors could not be } \\
\text { blind to group assignment for these outcomes }\end{array}$ \\
\hline $\begin{array}{l}\text { Incomplete } \\
\text { outcome data } \\
\text { (attrition bias) } \\
\text { All outcomes }\end{array}$ & Low risk & $\begin{array}{l}36 \text { women were randomized, } 2 \text { women did not receive their assigned } \\
\text { intervention and there were no losses to follow-up. Reasons were } \\
\text { provided for why the } 2 \text { mothers did not receive their allocated } \\
\text { intervention. Data were analyzed on } 17 \text { mothers in the SSC group and } 17 \\
\text { in the control group }\end{array}$ \\
\hline $\begin{array}{l}\text { Selective } \\
\text { reporting } \\
\text { (reporting bias) }\end{array}$ & Low risk & $\begin{array}{l}\text { All outcomes were listed under the aims of the study. Numerical results } \\
\text { for all outcomes, except infant crying were reported }\end{array}$ \\
\hline
\end{tabular}


Other bias High risk

Infants in both groups were bathed in the neonatal ward before being returned to their mothers. Bathing (as well as SSC) would influence the temperature outcomes. Mothers in both groups were instructed about how to breastfeed

\section{Hales 1977}

\begin{tabular}{|c|c|c|}
\hline Methods & \multicolumn{2}{|c|}{ Randomized controlled trial. } \\
\hline Participants & \multicolumn{2}{|c|}{60 healthy full term infants randomized into 3 groups. } \\
\hline Interventions & \multicolumn{2}{|c|}{$\begin{array}{l}\text { 1) Control group = glance at babies immediately after delivery, swaddled infants brought to } \\
\text { bedside at } 12 \text { hours postbirth, then daytime rooming-in. } \\
\text { 2) Early contact group }=45 \mathrm{~min} \text { of SSC immediately postbirth, daytime rooming-in. 3) Delayed } \\
\text { contact group }=45 \text { min of SSC at } 12 \text { hours postbirth, daytime rooming-in }\end{array}$} \\
\hline Outcomes & \multicolumn{2}{|c|}{$\begin{array}{l}\text { Observation of maternal affectionate, proximity maintaining and caretaking behavior at } 36 \\
\text { hours postbirth }\end{array}$} \\
\hline Notes & \multicolumn{2}{|c|}{ Study was done with low-income, urban, breastfeeding primipara in Guatemala city } \\
\hline \multicolumn{3}{|l|}{ Risk of bias } \\
\hline Bias & Authors' judgement & Support for judgement \\
\hline $\begin{array}{l}\text { Random sequence } \\
\text { generation (selection } \\
\text { bias) }\end{array}$ & Unclear risk & "Twenty mothers were randomly assigned to each of three groups" \\
\hline $\begin{array}{l}\text { Allocation } \\
\text { concealment } \\
\text { (selection bias) }\end{array}$ & Unclear risk & "Twenty mothers were randomly assigned to each of three groups" \\
\hline $\begin{array}{l}\text { Blinding } \\
\text { (performance bias } \\
\text { and detection bias) } \\
\text { All outcomes }\end{array}$ & Unclear risk & $\begin{array}{l}\text { It was not clear whether the lack of blinding would affect maternal or } \\
\text { clinician behavior. It was stated that observation of maternal behavior } \\
\text { was carried out by an investigator who was not aware of group } \\
\text { assignment }\end{array}$ \\
\hline $\begin{array}{l}\text { Incomplete outcome } \\
\text { data (attrition bias) } \\
\text { All outcomes }\end{array}$ & Low risk & $\begin{array}{l}60 \text { mothers were randomized and followed up at } 36 \text { hours. It appeared } \\
\text { that all women were accounted for, although denominators were not } \\
\text { provided in the results tables. }\end{array}$ \\
\hline $\begin{array}{l}\text { Selective reporting } \\
\text { (reporting bias) }\end{array}$ & Unclear risk & Assessment from brief study report. \\
\hline Other bias & Unclear risk & $\begin{array}{l}\text { There was little information on study methods. It was stated that } \\
\text { groups were comparable at baseline although it appeared that groups } \\
\text { were not balanced in terms of infant sex; in the } 2 \text { intervention groups } \\
14 / 20 \text { and } 13 / 20 \text { babies were female compared with } 7 / 20 \text { in the control } \\
\text { group }\end{array}$ \\
\hline
\end{tabular}

Huang 2006

\begin{tabular}{ll}
\hline Methods & Randomized controlled trial, states random digit table on page 43 \\
\hline Participants & $\begin{array}{l}78 \text { mothers who had spinal anesthesia for cesarean birth and their full term infants who were } \\
\text { hypothermic (body temperature }<36.5^{\circ} \mathrm{C} \text { ) postbirth }\end{array}$ \\
\hline Interventions & $\begin{array}{l}\text { Control group = infants received routine care while under a radiant warmer } \\
\text { KC group = infants were placed skin-to-skin between their mother's breasts after the mothers felt } \\
\text { comfortable approximately } 50 \text { min postcesarean birth and covered with blankets. The duration of } \\
\text { KC was } 30 \text { min. The infant's rectal temperature was taken after } 30 \text { min of KC and then every hour } \\
\text { until the temperature was back to normal. If the rectal temperature was }<36.5 \text {, the infant was placed } \\
\text { under a radiant warmer. The researchers did not state how many KC infants had rectal temperatures } \\
<36.5 \text { at the end of the intervention }\end{array}$ \\
\hline
\end{tabular}


Outcomes

The infant's rectal temperature was taken 30 min after $\mathrm{KC}$ started or after radiant warmer care. Infant temperature was recorded hourly starting 1 hour until 6 hours postbirth and was plotted on a graph. The number and \% of infants in each group who reached normal body temperature after 4 hours was listed

\begin{tabular}{|c|c|c|}
\hline Notes & Study was conducted in Taiwan. & \\
\hline \multicolumn{3}{|l|}{ Risk of bias } \\
\hline Bias & Authors' judgement & Support for judgement \\
\hline $\begin{array}{l}\text { Random } \\
\text { sequence } \\
\text { generation } \\
\text { (selection bias) }\end{array}$ & Low risk & $\begin{array}{l}\text { Abstract states "randomized control trial." States } \\
\text { random digit table on page } 43\end{array}$ \\
\hline $\begin{array}{l}\text { Allocation } \\
\text { concealment } \\
\text { (selection bias) }\end{array}$ & Unclear risk & No information provided other than random digit table. \\
\hline $\begin{array}{l}\text { Blinding } \\
\text { (performance } \\
\text { bias and } \\
\text { detection bias) } \\
\text { All outcomes }\end{array}$ & Unclear risk & No information provided. \\
\hline $\begin{array}{l}\text { Incomplete } \\
\text { outcome data } \\
\text { (attrition bias) } \\
\text { All outcomes }\end{array}$ & Low risk & $\begin{array}{l}86 \text { mothers agreed to participate in the study but data } \\
\text { were analyzed for only } 78 \text { infants. } 2 \text { mothers withdrew } \\
\text { because they were tired. } 4 \text { mothers felt cold and began } \\
\text { to shiver. The other } 2 \text { mothers exhibited tachypnea. It } \\
\text { was not clear which of these mothers were in the KC } \\
\text { and control groups }\end{array}$ \\
\hline $\begin{array}{l}\text { Selective } \\
\text { reporting } \\
\text { (reporting bias) }\end{array}$ & Unclear risk & $\begin{array}{l}\text { Data collected on the } \% \text { of infants in each group who } \\
\text { achieved normal body temperature }\left(36.5^{\circ} \mathrm{C} \text {. }\right) \text { after } 1-6 \\
\text { hours and plotted on a graph, numerical data provided } \\
\text { for only hour } 4\end{array}$ \\
\hline
\end{tabular}

Kastner 2005

\begin{tabular}{|c|c|c|}
\hline Methods & \multicolumn{2}{|c|}{ Randomized controlled trial, no other information provided. } \\
\hline Participants & \multicolumn{2}{|c|}{57 vaginally delivered mothers intending to breastfeed and their healthy full term infants } \\
\hline Interventions & \multicolumn{2}{|c|}{$\begin{array}{l}\text { In the usual care condition the mother and her infant remained together for } 20 \text { min. immediately } \\
\text { postbirth. Then they were separated for routine infant care (weighing, measuring). Next the infant } \\
\text { was dressed and returned to the mother for the first breastfeeding In the SSC group the mother and } \\
\text { infant spent the first hour postbirth alone and undisturbed as much as possible }\end{array}$} \\
\hline Outcomes & \multicolumn{2}{|c|}{$\begin{array}{l}4 \text { mother-child relationship scales (maternal physical contact, maternal speech/verbal } \\
\text { communication, maternal breastfeeding, child to mother contact), infant attempts to reach the } \\
\text { breast and grasp the nipple independently. } 3 \text { additional scales evaluating maternal fatigue and } \\
\text { anxiety, partner support, maternal medication administration }\end{array}$} \\
\hline Notes & \multicolumn{2}{|c|}{ Study was conducted in Munich, Germany. } \\
\hline \multicolumn{3}{|l|}{ Risk of bias } \\
\hline Bias & Authors' judgement & Support for judgement \\
\hline $\begin{array}{l}\text { Random } \\
\text { sequence } \\
\text { generation } \\
\text { (selection bias) }\end{array}$ & Unclear risk & $\begin{array}{l}\text { Summary states that the study was "prospective and } \\
\text { randomized." No further information provided }\end{array}$ \\
\hline $\begin{array}{l}\text { Allocation } \\
\text { concealment } \\
\text { (selection bias) }\end{array}$ & Unclear risk & No information provided. \\
\hline $\begin{array}{l}\text { Blinding } \\
\text { (performance } \\
\text { bias and } \\
\text { detection bias) }\end{array}$ & Low risk & $\begin{array}{l}\text { Mothers were told that the study involved "observation of } \\
\text { healthy newborns and their behavior in the first hour after } \\
\text { childbirth as well as their further development in the early } \\
\text { weeks of the child's life," not the true purpose of the study }\end{array}$ \\
\hline
\end{tabular}

Cochrane Database Syst Rev. Author manuscript; available in PMC 2014 April 08. 
All outcomes

\begin{tabular}{|c|c|c|}
\hline $\begin{array}{l}\text { Incomplete } \\
\text { outcome data } \\
\text { (attrition bias) } \\
\text { All outcomes }\end{array}$ & Unclear risk & $\begin{array}{l}\text { At } 3-5 \text { days postbirth, } 4 / 31 \text { infants were missing from the } \\
\text { intervention group and } 5 / 26 \text { for the control group; at } 5-6 \\
\text { weeks postbirth } 7 / 31 \text { infants were missing from the } \\
\text { intervention group and } 9 / 26 \text { from the control group. No } \\
\text { reasons were provided for participant attrition } \\
\text { No standard deviations were reported for mean outcome } \\
\text { data on scales } 1-4\end{array}$ \\
\hline $\begin{array}{l}\text { Selective } \\
\text { reporting } \\
\text { (reporting bias) }\end{array}$ & Unclear risk & $\begin{array}{l}\text { No numerical data were reported for scales 5-7 although } \\
\text { the results were stated as insignificant }\end{array}$ \\
\hline Other bias & Unclear risk & $\begin{array}{l}\text { The researchers acknowledge that video recording is a } \\
\text { "disturbance" to the mother. The amount that video } \\
\text { recording might have altered the mother's behavior is } \\
\text { unknown }\end{array}$ \\
\hline
\end{tabular}

\section{Khadivzadeh 2008}

\begin{tabular}{|c|c|c|}
\hline Methods & \multicolumn{2}{|c|}{ Randomized controlled trial. The randomization method was not described } \\
\hline Participants & \multicolumn{2}{|c|}{$\begin{array}{l}92 \text { primigravid mothers and their healthy full term infants delivering at Om-ol-banin Hospital in } \\
\text { Mashhad, Iran }\end{array}$} \\
\hline Interventions & \multicolumn{2}{|c|}{$\begin{array}{l}\text { Control: the infant was shown briefly to the mother before being placed under a radiant warmer for } \\
\text { routine care (physical assessment, vitamin K injection). The infant was then given to the mother } \\
\text { wrapped in a blanket after the perineal or episiotomy repair and the mother was encouraged to start } \\
\text { breastfeeding } \\
\text { SSC: the infant was placed prone between mother's breasts skin-to-skin immediately postbirth. The } \\
\text { infant's head was covered with a hat, and the back with a warm blanket. The infant was moved next } \\
\text { to the breast and the mother was encouraged to start breastfeeding as soon as the infant displayed } \\
\text { prefeeding behaviors. The Apgar score was assessed during SSC; all routine care was delayed until } \\
\text { the infant was } 2 \text { hours postbirth }\end{array}$} \\
\hline Outcomes & \multicolumn{2}{|c|}{$\begin{array}{l}\text { Duration from birth until the first breastfeeding, number of infants breastfeeding during the first } 30 \\
\text { min. postbirth, success and duration of the first breastfeeding, maternal feelings about SSC during } \\
\text { the first } 2 \text { hours postbirth }\end{array}$} \\
\hline \multicolumn{3}{|l|}{ Notes } \\
\hline \multicolumn{3}{|l|}{ Risk of bias } \\
\hline Bias & Authors' judgement & Support for judgement \\
\hline $\begin{array}{l}\text { Random } \\
\text { sequence } \\
\text { generation } \\
\text { (selection bias) }\end{array}$ & Unclear risk & $\begin{array}{l}\text { States randomized controlled trial at the beginning of the } \\
\text { Methods section. No further information provided }\end{array}$ \\
\hline $\begin{array}{l}\text { Allocation } \\
\text { concealment } \\
\text { (selection bias) }\end{array}$ & Unclear risk & No information provided. \\
\hline $\begin{array}{l}\text { Blinding } \\
\text { (performance } \\
\text { bias and } \\
\text { detection bias) } \\
\text { All outcomes }\end{array}$ & Unclear risk & $\begin{array}{l}\text { No information provided. However, IBFAT scores were } \\
\text { obtained during the first breastfeeding when the infants } \\
\text { were either SSC or wrapped in a blanket so the outcome } \\
\text { assessors could not be blind to group assignment for this } \\
\text { outcome }\end{array}$ \\
\hline $\begin{array}{l}\text { Incomplete } \\
\text { outcome data } \\
\text { (attrition bias) } \\
\text { All outcomes }\end{array}$ & Low risk & $\begin{array}{l}\text { The trial included } 92 \text { mothers and their infants, } 47 \\
\text { received SSC and } 45 \text { received routine care. Data were } \\
\text { analyzed on all the participants }\end{array}$ \\
\hline $\begin{array}{l}\text { Selective } \\
\text { reporting } \\
\text { (reporting bias) }\end{array}$ & Unclear risk & $\begin{array}{l}\text { Numerical data were reported for all the outcomes } \\
\text { identified in the results section Data were also collected } \\
\text { on maternal attachment and anxiety, results were } \\
\text { reported elsewhere }\end{array}$ \\
\hline
\end{tabular}

Cochrane Database Syst Rev. Author manuscript; available in PMC 2014 April 08. 
Other bias High risk
SSC infants were placed prone between their mother's breasts immediately postbirth and then left undisturbed. The control infants received a number of co-

interventions (physical assessment, vitamin $\mathrm{K}$ injection) which could have been disruptive to their ability to breastfeed

\section{Mazurek 1999}

\begin{tabular}{|c|c|c|}
\hline Methods & \multicolumn{2}{|c|}{ Randomized controlled trial. } \\
\hline Participants & \multicolumn{2}{|c|}{66 healthy full term infants and their mothers (mean GA 39 weeks) } \\
\hline Interventions & \multicolumn{2}{|c|}{$\begin{array}{l}\text { After birth all infants were dried, cord blood PH was drawn and measurements were taken. } \\
\text { 1) SSC group = the infant was placed in their mother's arms SSC 6-8 min postbirth and both were } \\
\text { covered with a sheet. SSC continued for } 75 \text { min. 2) Mother's arms group }=\text { the infant was wrapped } \\
\text { in a blanket and given to the mother to hold for } 75 \text { min. 3) Control group }=\text { the infant was wrapped } \\
\text { and kept at a distance from their mother in the same room }\end{array}$} \\
\hline Outcomes & \multicolumn{2}{|c|}{$\begin{array}{l}\text { Crying time, blood glucose, } \mathrm{HR} \text { and respiratory rate at } 75 \text { min postbirth, blood } \mathrm{PH} \text {, skin thigh } \\
\text { temperature }\end{array}$} \\
\hline Notes & \multicolumn{2}{|c|}{ Study was done in Warsaw, Poland. } \\
\hline \multicolumn{3}{|l|}{ Risk of bias } \\
\hline Bias & Authors' judgement & Support for judgement \\
\hline $\begin{array}{l}\text { Random } \\
\text { sequence } \\
\text { generation } \\
\text { (selection bias) }\end{array}$ & Unclear risk & $\begin{array}{l}\text { Women were divided into "three randomised groups". } \\
\text { Methods not described }\end{array}$ \\
\hline $\begin{array}{l}\text { Allocation } \\
\text { concealment } \\
\text { (selection bias) }\end{array}$ & Unclear risk & Methods not described. \\
\hline $\begin{array}{l}\text { Blinding } \\
\text { (performance bias } \\
\text { and detection } \\
\text { bias) } \\
\text { All outcomes }\end{array}$ & Unclear risk & $\begin{array}{l}\text { There was no mention of blinding and some of the } \\
\text { outcomes (infant crying behavior) and temperature may } \\
\text { have been susceptible to observer bias. Other outcomes } \\
\text { may not have been affected by lack of blinding (arterial } \\
\text { blood gases) }\end{array}$ \\
\hline $\begin{array}{l}\text { Incomplete } \\
\text { outcome data } \\
\text { (attrition bias) All } \\
\text { outcomes }\end{array}$ & Low risk & $\begin{array}{l}66 \text { women were randomized and all appeared to be } \\
\text { accounted for in the results and analyses; the period of } \\
\text { follow-up was short ( } 75 \text { min). It was not clear whether } \\
\text { there was any missing data. }\end{array}$ \\
\hline $\begin{array}{l}\text { Selective } \\
\text { reporting } \\
\text { (reporting bias) }\end{array}$ & Unclear risk & $\begin{array}{l}\text { Large number of data collection points and measures. } \\
\text { Assessment from published report only }\end{array}$ \\
\hline Other bias & Unclear risk & $\begin{array}{l}\text { Baseline imbalance not apparent. } \\
\text { There was little information on study methods. } \\
\text { Assessment of risk of bias was from abstract and } \\
\text { translation notes (original paper not in English) }\end{array}$ \\
\hline
\end{tabular}

McClellan 1980

\begin{tabular}{ll}
\hline Methods & Randomized controlled trial (table of random numbers). \\
\hline Participants & 40 healthy full term infants born by repeat cesarean section (spinal anesthesia) \\
\hline Interventions & $\begin{array}{l}\text { 1) Control group }=\text { visual contact }<5 \text { min, holding the swaddled infant for } 10-20 \text { min in the } \\
\text { nursery during the first } 12 \text { hours postbirth, then rooming-in. 2) Early contact group }=\text { visual } \\
\text { contact for } 5 \text { to } 15 \text { min, SSC for the first hour in the recovery room, then rooming-in }\end{array}$ \\
\hline
\end{tabular}

Cochrane Database Syst Rev. Author manuscript; available in PMC 2014 April 08. 
Outcomes 1) Neonatal Perception Inventory. 2) Postnatal research inventory. 3) Observation of maternal behavior.

All variables measured on postpartum day 1 or 2 and 28-32 days postbirth

\begin{tabular}{|c|c|c|}
\hline Notes & \multicolumn{2}{|c|}{ Study was done with middle-income, multipara in the USA. } \\
\hline \multicolumn{3}{|l|}{ Risk of bias } \\
\hline Bias & Authors' judgement & Support for judgement \\
\hline $\begin{array}{l}\text { Random } \\
\text { sequence } \\
\text { generation } \\
\text { (selection bias) }\end{array}$ & Unclear risk & $\begin{array}{l}\text { Stated that a table of random numbers was used to ensure "no systematic } \\
\text { bias" but then went on to say that "if the woman did not meet the } \\
\text { characteristics of the population, she was replaced by the next woman } \\
\text { who qualified, until there were } 20 \text { mothers in each group" } \\
\text { It was not clear at what point randomization occurred or how many } \\
\text { women were randomized and excluded postrandomization and then } \\
\text { replaced }\end{array}$ \\
\hline $\begin{array}{l}\text { Allocation } \\
\text { concealment } \\
\text { (selection bias) }\end{array}$ & High risk & $\begin{array}{l}\text { Women were "randomly assigned", "if the woman did not meet the } \\
\text { characteristics of the population, she was replaced by the next woman } \\
\text { who qualified, until there were } 20 \text { mothers in each group" } \\
\text { It was not clear at what point randomization occurred or how many } \\
\text { women were randomized and excluded postrandomization and then } \\
\text { replaced }\end{array}$ \\
\hline $\begin{array}{l}\text { Blinding } \\
\text { (performance } \\
\text { bias and } \\
\text { detection bias) } \\
\text { All outcomes }\end{array}$ & Unclear risk & $\begin{array}{l}\text { Women would be aware of which group they were in and would be aware } \\
\text { of observations. Clinical staff would be aware of group assignment. It was } \\
\text { stated that the nurses carrying out observations were unaware of group } \\
\text { assignment }\end{array}$ \\
\hline $\begin{array}{l}\text { Incomplete } \\
\text { outcome data } \\
\text { (attrition bias) } \\
\text { All outcomes }\end{array}$ & Unclear risk & $\begin{array}{l}\text { It was not clear how many women were randomized and then later } \\
\text { excluded and replaced. } 40 \text { women received the intervention and all } \\
\text { seemed to be accounted for in the analysis. It was not clear if there was } \\
\text { any missing data. }\end{array}$ \\
\hline $\begin{array}{l}\text { Selective } \\
\text { reporting } \\
\text { (reporting bias) }\end{array}$ & Unclear risk & $\begin{array}{l}\text { All outcomes specified in the introduction were reported on, it is not clear } \\
\text { if other outcomes were measured, we did not have access to the study } \\
\text { protocol. }\end{array}$ \\
\hline Other bias & Unclear risk & $\begin{array}{l}\text { Groups appeared similar at baseline. } \\
\text { It was not clear what the mean scores reported represented, e.g. a mean } \\
\text { mother and infant behavior score (from observation) - whether a higher } \\
\text { score was more positive or what was being recorded. The measure is } \\
\text { referenced but without knowing how scoring works it is not easy to } \\
\text { interpret the results }\end{array}$ \\
\hline
\end{tabular}

Mizuno 2004

\begin{tabular}{ll}
\hline Methods & Randomized controlled trial. \\
\hline Participants & 60 healthy full term infants $>37$ weeks' gestation and their mothers \\
\hline Interventions & $\begin{array}{l}\text { 1) SSC group = extensive SSC (M = 63.7 min) immediately postbirth with effective suckling. } \\
\text { Then mothers and infants were separated for 24 hours and infants were fed formula. After } 24 \\
\text { hours rooming-in with q3hr breastfeedings. 2) Control group = first mother-infant contact } 24 \\
\text { hours postbirth then rooming-in and q3hr breastfeedings. Midwives assisted both groups with the } \\
\text { first breastfeeding }\end{array}$ \\
\hline Outcomes & $\begin{array}{l}\text { Frequency of mouthing movements with exposure to own mother's milk, another mother's milk, } \\
\text { formula, orange juice, distilled water at } 1 \text { and } 4 \text { days of age. Difference in frequency of } \\
\text { mouthing movements between mother's milk and another mother's milk at } 1 \text { and } 4 \text { days of age, } \\
\text { duration of breastfeeding }\end{array}$ \\
\hline Notes & Study was done in Chiba, Japan. \\
\hline Risk of bias & Authors' judgement Support for judgement \\
\hline Bias &
\end{tabular}


Random sequence generation

(selection bias)

\begin{tabular}{|c|c|c|}
\hline $\begin{array}{l}\text { Allocation } \\
\text { concealment } \\
\text { (selection bias) }\end{array}$ & Unclear risk & "randomly assigned". \\
\hline $\begin{array}{l}\text { Blinding } \\
\text { (performance bias } \\
\text { and detection bias) } \\
\text { All outcomes }\end{array}$ & Unclear risk & $\begin{array}{l}\text { Main outcome was baby reaction to various odor stimuli, it is unlikely } \\
\text { that lack of maternal blinding would have affected this. Staff providing } \\
\text { care would be aware of group assignment and it was not clear whether } \\
\text { those carrying out infant observations were aware of group assignment, } \\
\text { it was stated that interviewers collecting longer term breastfeeding } \\
\text { outcome data were blind to group allocation }\end{array}$ \\
\hline $\begin{array}{l}\text { Incomplete } \\
\text { outcome data } \\
\text { (attrition bias) All } \\
\text { outcomes }\end{array}$ & Unclear risk & $\begin{array}{l}60 \text { women were included, } 30 \text { in each group, } 2 \text { women were lost from } \\
\text { the control group. Denominators were not provided on tables or figures, } \\
\text { so it was not clear how many women were followed up after hospital } \\
\text { discharge }\end{array}$ \\
\hline $\begin{array}{l}\text { Selective reporting } \\
\text { (reporting bias) }\end{array}$ & Unclear risk & $\begin{array}{l}\text { Assessment carried out from published report. The validity of the main } \\
\text { outcome measure and the method of observing infant response were not } \\
\text { clear. }\end{array}$ \\
\hline Other bias & Unclear risk & No baseline imbalance between groups reported. \\
\hline
\end{tabular}

Moore 2005

\begin{tabular}{|c|c|c|}
\hline Methods & \multicolumn{2}{|c|}{ Randomized controlled trial (computerized minimization technique) } \\
\hline Participants & \multicolumn{2}{|c|}{20 healthy full term infants $>37$ weeks' gestation and their mothers } \\
\hline Interventions & \multicolumn{2}{|c|}{$\begin{array}{l}\text { 1) SSC group = infant placed prone SSC on mothers abdomen. Baby moved to warmer after cord } \\
\text { cut. Then infant placed prone on mother's bare chest between breasts. Moved to cross cradle nursing } \\
\text { position when infant displayed early hunger cues ( } \mathrm{M}=99.5 \text { min of SSC) Breastfeeding assistance } \\
\text { provided by researcher. } 2 \text { ) Control group = infant shown briefly to mother and moved to warmer. } \\
\text { Then infant swaddled in blankets and held by mother. Moved to cross cradle nursing position when } \\
\text { infant displayed early hunger cues. Breastfeeding assistance provided by researcher }\end{array}$} \\
\hline Outcomes & \multicolumn{2}{|c|}{$\begin{array}{l}\text { Success of the } 1 \text { st breastfeeding, time of effective breastfeeding, body weight change day } 14 \\
\text { postbirth, number of breastfeeding problems in the } 1 \text { st postpartum month, mother's perception of the } \\
\text { adequacy of her milk supply, maternal parenting confidence, breastfeeding status } 1 \text { month postbirth }\end{array}$} \\
\hline Notes & \multicolumn{2}{|c|}{ Study was done in the USA with primarily Caucasian, married, college-educated primipara } \\
\hline \multicolumn{3}{|l|}{ Risk of bias } \\
\hline Bias & Authors' judgement & Support for judgement \\
\hline $\begin{array}{l}\text { Random } \\
\text { sequence } \\
\text { generation } \\
\text { (selection bias) }\end{array}$ & Low risk & Computer-generated minimization process. \\
\hline $\begin{array}{l}\text { Allocation } \\
\text { concealment } \\
\text { (selection bias) }\end{array}$ & Low risk & Assignment by computer minimization process. \\
\hline $\begin{array}{l}\text { Blinding } \\
\text { (performance } \\
\text { bias and } \\
\text { detection bias) } \\
\text { All outcomes }\end{array}$ & Unclear risk & $\begin{array}{l}\text { This was an unblinded study. Participants were aware of } \\
\text { group assignment. The chief investigator provided some of } \\
\text { the postbirth care (including help with breastfeeding) and } \\
\text { collected some of the outcome data }\end{array}$ \\
\hline $\begin{array}{l}\text { Incomplete } \\
\text { outcome data } \\
\text { (attrition bias) } \\
\text { All outcomes }\end{array}$ & Low risk & 20 of the 23 women randomized were followed up. \\
\hline $\begin{array}{l}\text { Selective } \\
\text { reporting } \\
\text { (reporting bias) }\end{array}$ & Unclear risk & $\begin{array}{l}\text { All outcomes appear to have been reported. Assessment from } \\
\text { published trial report }\end{array}$ \\
\hline
\end{tabular}

Cochrane Database Syst Rev. Author manuscript; available in PMC 2014 April 08. 
Other bias $\quad$ Low risk $\quad$ Groups appeared similar at baseline (randomization by minimization technique)

\section{Nolan 2009}

\begin{tabular}{|c|c|c|}
\hline Methods & \multicolumn{2}{|c|}{$\begin{array}{l}\text { Randomized controlled trial (mothers were randomly assigned to the Nursing Intervention to } \\
\text { Minimize Maternal-Infant Separation (NIMS) or control group by a coin flip) }\end{array}$} \\
\hline Participants & \multicolumn{2}{|c|}{$\begin{array}{l}50 \text { women scheduled for a repeat cesarean delivery with regional anesthesia and their healthy full } \\
\text { term infants }\end{array}$} \\
\hline Interventions & \multicolumn{2}{|c|}{$\begin{array}{l}\text { Control: standard/usual postoperative OB care was unstructured. The mothers typically had brief } \\
\text { physical or no contact with their infants until they were admitted to the obstetric postanesthesia care } \\
\text { unit. Breastfeeding was sometimes included. SSC was not routinely encouraged in the PACU } \\
\text { Intervention: a minimum of } 10-15 \text { min of SSC was offered in the PACU as part of a NIMS protocol } \\
\text { which included a number of co-interventions such as intra-/postoperative environmental } \\
\text { manipulation to maintain a maternal-infant spatial distance of less than } 8 \mathrm{ft} \text {. with uninterrupted } \\
\text { maternal visual and auditory contact, en face presentation at birth, and intraoperative cheek-to- } \\
\text { cheek contact for a minimum of } 3 \text { min. The NIMS intraoperative protocol could be considered a } \\
\text { sensory intervention which is a preamble to SSC in a situation where it is impossible to implement } \\
\text { SSC immediately postbirth The mean duration of SSC was } 33+13 \text { min. }\end{array}$} \\
\hline Outcomes & \multicolumn{2}{|c|}{$\begin{array}{l}\text { Maternal pain, anxiety, infant respiratory rate, temperature, salivary cortisol, breastfeeding initiation } \\
\text { in the PACU, breastfeeding at hospital discharge and at } 4 \text { weeks postbirth, maternal perception of } \\
\text { childbirth }\end{array}$} \\
\hline Notes & \multicolumn{2}{|c|}{ This study took place in the US. } \\
\hline \multicolumn{3}{|l|}{ Risk of bias } \\
\hline Bias & Authors' judgement & Support for judgement \\
\hline $\begin{array}{l}\text { Random } \\
\text { sequence } \\
\text { generation } \\
\text { (selection bias) }\end{array}$ & Low risk & $\begin{array}{l}\text { Mothers were randomly assigned to the NIMS or control group by a coin } \\
\text { flip }\end{array}$ \\
\hline $\begin{array}{l}\text { Allocation } \\
\text { concealment } \\
\text { (selection bias) }\end{array}$ & Low risk & $\begin{array}{l}\text { The researchers obtained informed consent from interested mothers when } \\
\text { they arrived on the obstetrics ward and then randomly assigned the mothers } \\
\text { to groups by a coin flip }\end{array}$ \\
\hline $\begin{array}{l}\text { Blinding } \\
\text { (performance } \\
\text { bias and } \\
\text { detection bias) } \\
\text { All outcomes }\end{array}$ & Unclear risk & $\begin{array}{l}\text { The nurses who provided usual care to the control mothers were unfamiliar } \\
\text { with the NIMS protocol } \\
\text { No information was provided about whether the research nurse who } \\
\text { conducted the medical record reviews, and obtained salivary cortisol } \\
\text { samples was blind to participant group assignment }\end{array}$ \\
\hline $\begin{array}{l}\text { Incomplete } \\
\text { outcome data } \\
\text { (attrition bias) } \\
\text { All outcomes }\end{array}$ & Unclear risk & $\begin{array}{l}72 \text { mothers were recruited to participate in the study. } 23 \% \text { of the mothers } \\
\text { did not receive their assigned intervention for various reasons such as } \\
\text { unplanned general anesthesia, infant medical complications, staffing } \\
\text { issues. There were } 25 \text { mother infant pairs in each group. } 30 \%(\mathrm{n}=15) \text { of } \\
\text { the mothers has some missing pain scores. The number of missing pain } \\
\text { scores did not differ significantly between groups. } 30 \%(\mathrm{n}=15) \text { of the } \\
\text { infants had some missing temperature and salivary cortisol data. More } \\
\text { infants in the NIMS group had missing salivary cortisol data. The number } \\
\text { of missing infant temperature data did not differ significantly between } \\
\text { groups. } 36 \%(\mathrm{n}=18) \text { of the infants had missing respiratory rate data. The } \\
\text { amount of missing respiratory data did not differ significantly between } \\
\text { groups }\end{array}$ \\
\hline $\begin{array}{l}\text { Selective } \\
\text { reporting } \\
\text { (reporting bias) }\end{array}$ & Low risk & Numerical data were provided for all outcomes. \\
\hline Other bias & High risk & $\begin{array}{l}\text { This study was included with considerable caution due to the following } \\
\text { issues } \\
\text { Infants in the SSC group weighed significantly more }(3585.40+546.5 \mathrm{~g}) \\
\text { than those in the control group }(3299.60+374.7 \mathrm{~g})(\mathrm{P}<.04) \text {. } \\
\text { On admission to the PACU, before SSC was initiated, infants in the NIMS } \\
\text { group had significantly higher salivary cortisol levels }(\mathrm{M}=3.27+1.43) \\
\text { than infants in the control group }(\mathrm{M}=1.90+0.72) \text {. }\end{array}$ \\
\hline
\end{tabular}

Cochrane Database Syst Rev. Author manuscript; available in PMC 2014 April 08. 
There were a number of co-interventions in this study. Therefore, it is impossible to disentangle the effects of SSC from those of the other interventions

Usual care was unstructured. The exact conditions which the NIMS protocol was being compared to are unknown.

\section{Punthmatharith 2001}

\begin{tabular}{|c|c|c|}
\hline Methods & \multicolumn{2}{|c|}{ Randomized controlled trial (computerized minimization technique) } \\
\hline Participants & \multicolumn{2}{|c|}{196 healthy full term $37-42$ weeks' gestation infants and their mothers } \\
\hline Interventions & \multicolumn{2}{|c|}{$\begin{array}{l}\text { All infants received standard care for the } 1 \mathrm{st} 30-60 \text { min postbirth. After the cord was clamped they } \\
\text { were shown briefly to mom and moved to a warmer. } 1 \text { ) SSC group = beginning } 60 \text { min postbirth } \\
\text { infants received (M = } 30 \text { min) of SSC. Mothers were encouraged to breastfeed on infant demand. } \\
\text { Infants and mothers transferred to the postpartum unit at } 120 \text { min postbirth for } 24 \text { hour rooming-in. } \\
\text { Mothers encouraged to provide SSC } 15-30 \text { min before each breastfeeding. No other fluids given to } \\
\text { infants. 2) Control group = swaddled infant given to mom after episiotomy repair and they were } \\
\text { transferred together to the recovery room for } 2 \text { hours, then to postpartum for } 24 \text { hour rooming-in. } \\
\text { Mothers encouraged to breastfeed on infant demand. Cup feeding was encouraged if the infant } \\
\text { required supplementation }\end{array}$} \\
\hline Outcomes & \multicolumn{2}{|c|}{$\begin{array}{l}\text { Observation of maternal affectionate behaviors during a breastfeeding at } 36-48 \text { hours postbirth, } 4 \\
\text { subscales of the maternal-infant bonding questionnaire (attention/connection to the infant, } \\
\text { preparation for nurturing the infant, role of mother, breastfeeding the infant) at } 36-48 \text { hours and } \\
\text { week } 4 \text { postbirth, Mother's perception of the adequacy of her milk supply, and breastfeeding status } \\
36-48 \text { hours and week } 4 \text { postbirth, infant weight day } 2 \text { and } 1 \text { month postbirth }\end{array}$} \\
\hline Notes & \multicolumn{2}{|c|}{ Study was done in a Baby Friendly Hospital in Songkhla, Thailand } \\
\hline \multicolumn{3}{|l|}{ Risk of bias } \\
\hline Bias & Authors' judgement & Support for judgement \\
\hline $\begin{array}{l}\text { Random } \\
\text { sequence } \\
\text { generation } \\
\text { (selection bias) }\end{array}$ & Low risk & $\begin{array}{l}\text { Sequence generation was by computerized } \\
\text { minimization method with stratification for } 10 \text { factors } \\
\text { including parity, age, SES, medication, ward, planned } \\
\text { duration of breastfeeding, previous breastfeeding, } \\
\text { experience, infant weight and sex }\end{array}$ \\
\hline $\begin{array}{l}\text { Allocation } \\
\text { concealment } \\
\text { (selection bias) }\end{array}$ & Low risk & $\begin{array}{l}\text { Computerized minimization method but no clear } \\
\text { description of what happened at the point of } \\
\text { randomization }\end{array}$ \\
\hline $\begin{array}{l}\text { Blinding } \\
\text { (performance } \\
\text { bias and } \\
\text { detection bias) } \\
\text { All outcomes }\end{array}$ & Unclear risk & $\begin{array}{l}\text { Mothers would be aware of group assignment and it } \\
\text { was stated that because of lack of privacy and cultural } \\
\text { factors mothers might feel reluctant to accept the } \\
\text { intervention. It was not clear whether there was an } \\
\text { attempt to blind staff or outcome assessors and the } \\
\text { impact of lack of blinding is not clear }\end{array}$ \\
\hline $\begin{array}{l}\text { Incomplete } \\
\text { outcome data } \\
\text { (attrition bias) } \\
\text { All outcomes }\end{array}$ & Unclear risk & $\begin{array}{l}195 \text { women were randomized and } 167 \text { remained } \\
\text { available to followup. Loss was balanced across groups }\end{array}$ \\
\hline $\begin{array}{l}\text { Selective } \\
\text { reporting } \\
\text { (reporting bias) }\end{array}$ & Unclear risk & Assessment from unpublished thesis. \\
\hline Other bias & Low risk & $\begin{array}{l}\text { Groups appeared comparable at baseline (stratified). } \\
\text { Recruitment was at convenient times, so the sample } \\
\text { may not have been representative of the population }\end{array}$ \\
\hline
\end{tabular}

Shiau 1997

Methods Randomized controlled trial (computerized minimization technique)




\begin{tabular}{|c|c|c|}
\hline Participants & \multicolumn{2}{|c|}{$\begin{array}{l}58 \text { healthy full term infants and their mothers randomized into } 1 \text { of } 2 \text { groups } 0-4 \text { hours } \\
\text { postvaginal or cesarean birth }\end{array}$} \\
\hline Interventions & \multicolumn{2}{|c|}{$\begin{array}{l}\text { 1) KC group = mothers began SSC at } 4 \text { hours postbirth and held their infants in SSC } 8 \text { hours } \\
\text { daily for } 3 \text { days. Breastfeeding based on infant hunger cues during the day and every } 4 \text { hours at } \\
\text { night. 2) Control group = began breastfeeding } 24 \text { hours postbirth. Mothers fed their infants every } \\
4 \text { hours in the nursery }\end{array}$} \\
\hline Outcomes & \multicolumn{2}{|c|}{$\begin{array}{l}\text { 1) Mean maternal state anxiety. 2) Mean score on } 6 \text { point breast engorgement scale. 3) Chest } \\
\text { circumference. 4) Breastfeeding status day } 3 \text { and } 28 \text { postbirth. 5) Breast milk maturation. 6) } \\
\text { Breastfeeding duration }\end{array}$} \\
\hline Notes & \multicolumn{2}{|c|}{$\begin{array}{l}\text { Study was done with married primipara and multipara in Taiwan. The researcher provided all } \\
\text { nursing care to the SSC group during the day }\end{array}$} \\
\hline \multicolumn{3}{|l|}{ Risk of bias } \\
\hline Bias & Authors' judgement & Support for judgement \\
\hline $\begin{array}{l}\text { Random sequence } \\
\text { generation } \\
\text { (selection bias) }\end{array}$ & Low risk & $\begin{array}{l}\text { By computerized minimization technique taking account of gestational } \\
\text { and maternal age, infant sex, type of birth, maternal education and } \\
\text { previous BF experience }\end{array}$ \\
\hline $\begin{array}{l}\text { Allocation } \\
\text { concealment } \\
\text { (selection bias) }\end{array}$ & Low risk & Computerized assignment. \\
\hline $\begin{array}{l}\text { Blinding } \\
\text { (performance bias } \\
\text { and detection bias) } \\
\text { All outcomes }\end{array}$ & High risk & $\begin{array}{l}\text { There was no blinding in this study and care for the intervention group } \\
\text { was provided by the investigator who also gave advice on breastfeeding } \\
\text { and collected outcome data. The control group received care from } \\
\text { different staff. It is likely that other aspects of care as well as SSC would } \\
\text { be different between the } 2 \text { groups }\end{array}$ \\
\hline $\begin{array}{l}\text { Incomplete } \\
\text { outcome data } \\
\text { (attrition bias) All } \\
\text { outcomes }\end{array}$ & Low risk & $\begin{array}{l}58 \text { mother infant pairs were randomized and all were accounted for in } \\
\text { the analyses although there was some missing data for some outcomes. }\end{array}$ \\
\hline $\begin{array}{l}\text { Selective reporting } \\
\text { (reporting bias) }\end{array}$ & Unclear risk & Assessment from unpublished dissertation. \\
\hline Other bias & Unclear risk & $\begin{array}{l}\text { No baseline imbalance apparent. } \\
\text { The fact that care for the intervention and control groups was provided } \\
\text { by different staff may be a serious source of bias in this study }\end{array}$ \\
\hline
\end{tabular}

\section{Sosa 1976a}

\begin{tabular}{|c|c|c|}
\hline Methods & \multicolumn{2}{|c|}{ Randomized controlled trial (random numbers in sealed envelopes) } \\
\hline Participants & \multicolumn{2}{|c|}{60 healthy full term infants and their mothers randomized immediately after delivery } \\
\hline Interventions & \multicolumn{2}{|c|}{$\begin{array}{l}\text { 1) Experimental group = mothers held their infants in SSC for } 45 \text { min after the episiotomy repair. } \\
\text { They were encouraged to breastfeed. 2) Control group = infants were separated from their } \\
\text { mothers for } 12 \text { hours }\end{array}$} \\
\hline Outcomes & \multicolumn{2}{|c|}{ 1) Mean duration of breastfeeding. 2) Episodes of illness, growth and development, mortality } \\
\hline Notes & \multicolumn{2}{|c|}{ Study was done with poor, urban primipara from the marginal area of Guatemala city } \\
\hline \multicolumn{3}{|l|}{ Risk of bias } \\
\hline Bias & Authors' judgement & Support for judgement \\
\hline $\begin{array}{l}\text { Random sequence } \\
\text { generation } \\
\text { (selection bias) }\end{array}$ & Unclear risk & $\begin{array}{l}\text { "Assignment of mother-infant pairs.... was made from random } \\
\text { numbers.." }\end{array}$ \\
\hline $\begin{array}{l}\text { Allocation } \\
\text { concealment } \\
\text { (selection bias) }\end{array}$ & Unclear risk & $\begin{array}{l}\text { Allocations were concealed in sealed envelopes which were opened } \\
\text { immediately after delivery }\end{array}$ \\
\hline
\end{tabular}




\begin{tabular}{|c|c|c|}
\hline $\begin{array}{l}\text { Blinding } \\
\text { (performance bias } \\
\text { and detection bias) } \\
\text { All outcomes }\end{array}$ & Unclear risk & $\begin{array}{l}\text { Attempts to blind mothers, staff and outcome assessors were not } \\
\text { mentioned. Mothers would be aware of allocation, staff were also likely } \\
\text { to have been aware of treatment group and may have altered other } \\
\text { aspects of treatment and outcome assessors accompanied the mothers } \\
\text { home from hospital so may well have been aware of group allocation }\end{array}$ \\
\hline $\begin{array}{l}\text { Incomplete } \\
\text { outcome data } \\
\text { (attrition bias) All } \\
\text { outcomes }\end{array}$ & Unclear risk & $\begin{array}{l}60 \text { women. Denominators for longer tem outcomes were not specified so } \\
\text { it is not clear how many women remained available to follow-up at each } \\
\text { data collection point }\end{array}$ \\
\hline $\begin{array}{l}\text { Selective reporting } \\
\text { (reporting bias) }\end{array}$ & Unclear risk & $\begin{array}{l}\text { Assessment made from published reports only. In this study the } \\
\text { intervention appeared to have a negative effect on breastfeeding duration } \\
\text { this was explained by possibly different populations in the control and } \\
\text { intervention groups (although randomization should have controlled for } \\
\text { this). }\end{array}$ \\
\hline Other bias & Unclear risk & $\begin{array}{l}\text { There was some imbalance in the socioeconomic background of women } \\
\text { although this was not consistent across study sites Little information was } \\
\text { provided on study methods. } \\
\text { Women were followed up for } 9 \text { months or } 1 \text { year. Duration of } \\
\text { breastfeeding was an outcome. It is not clear whether any women were } \\
\text { still breastfeeding at the final data collection point. No SDs were } \\
\text { provided for continuous variables so some findings were difficult to } \\
\text { interpret }\end{array}$ \\
\hline
\end{tabular}

\section{Sosa 1976b}

\begin{tabular}{|c|c|c|}
\hline Methods & \multicolumn{2}{|c|}{ Randomized controlled trial (random numbers in sealed envelopes) } \\
\hline Participants & \multicolumn{2}{|c|}{68 healthy full term infants and their mothers randomized immediately after delivery } \\
\hline Interventions & \multicolumn{2}{|c|}{$\begin{array}{l}\text { 1) Experimental group }=\text { mothers held their infants in SSC for } 45 \text { min after the episiotomy } \\
\text { repair. They were encouraged to breastfeed. 2) Control group = infants were separated from their } \\
\text { mothers for } 12 \text { hours }\end{array}$} \\
\hline Outcomes & \multicolumn{2}{|c|}{ 1) Mean duration of breastfeeding. 2) Episodes of illness, growth and development, mortality } \\
\hline Notes & \multicolumn{2}{|c|}{ Study was done with poor, urban primipara from the marginal area of Guatemala city } \\
\hline \multicolumn{3}{|l|}{ Risk of bias } \\
\hline Bias & Authors' judgement & Support for judgement \\
\hline $\begin{array}{l}\text { Random sequence } \\
\text { generation } \\
\text { (selection bias) }\end{array}$ & Unclear risk & $\begin{array}{l}\text { "Assignment of mother-infant pairs.... was made from random } \\
\text { numbers.." }\end{array}$ \\
\hline $\begin{array}{l}\text { Allocation } \\
\text { concealment } \\
\text { (selection bias) }\end{array}$ & Unclear risk & $\begin{array}{l}\text { Allocations were concealed in sealed envelopes which were opened } \\
\text { immediately after delivery }\end{array}$ \\
\hline $\begin{array}{l}\text { Blinding } \\
\text { (performance bias } \\
\text { and detection bias) } \\
\text { All outcomes }\end{array}$ & Unclear risk & $\begin{array}{l}\text { Attempts to blind mothers, staff and outcome assessors were not } \\
\text { mentioned. Mothers would be aware of allocation, staff were also likely } \\
\text { to have been aware of treatment group and may have altered other } \\
\text { aspects of treatment and outcome assessors accompanied the mothers } \\
\text { home from hospital so may well have been aware of group allocation }\end{array}$ \\
\hline $\begin{array}{l}\text { Incomplete } \\
\text { outcome data } \\
\text { (attrition bias) All } \\
\text { outcomes }\end{array}$ & Unclear risk & $\begin{array}{l}68 \text { women. Denominators for longer tem outcomes were not specified } \\
\text { so it is not clear how many women remained available to follow-up at } \\
\text { each data collection point }\end{array}$ \\
\hline $\begin{array}{l}\text { Selective reporting } \\
\text { (reporting bias) }\end{array}$ & Unclear risk & Assessment made from published reports only. \\
\hline Other bias & Unclear risk & $\begin{array}{l}\text { There was some imbalance in the socioeconomic background of women } \\
\text { although this was not consistent across study sites Little information } \\
\text { was provided on study methods. } \\
\text { Women were followed up for } 9 \text { months or } 1 \text { year. Duration of } \\
\text { breastfeeding was an outcome. It is not clear whether any women were } \\
\text { still breastfeeding at the final data collection point. No SDs were }\end{array}$ \\
\hline
\end{tabular}

Cochrane Database Syst Rev. Author manuscript; available in PMC 2014 April 08. 
provided for continuous variables so some findings were difficult to interpret

\section{Sosa 1976c}

\begin{tabular}{|c|c|c|}
\hline Methods & \multicolumn{2}{|c|}{ Randomized controlled trial (random numbers in sealed envelopes) } \\
\hline Participants & \multicolumn{2}{|c|}{40 healthy full term infants and their mothers randomized immediately after delivery } \\
\hline Interventions & \multicolumn{2}{|c|}{$\begin{array}{l}\text { 1) Experimental group }=\text { mothers held their infants in SSC for } 45 \text { min after the episiotomy } \\
\text { repair. They were encouraged to breastfeed. 2) Control group }=\text { infants were separated from their } \\
\text { mothers for } 24 \text { hours }\end{array}$} \\
\hline Outcomes & \multicolumn{2}{|c|}{ 1) Mean duration of breastfeeding. 2) Episodes of illness, growth and development, mortality } \\
\hline Notes & \multicolumn{2}{|c|}{ Study was done with poor, urban primipara from the marginal area of Guatemala city } \\
\hline \multicolumn{3}{|l|}{ Risk of bias } \\
\hline Bias & Authors' judgement & Support for judgement \\
\hline $\begin{array}{l}\text { Random sequence } \\
\text { generation } \\
\text { (selection bias) }\end{array}$ & Unclear risk & $\begin{array}{l}\text { "Assignment of mother-infant pairs.... was made from random } \\
\text { numbers.." }\end{array}$ \\
\hline $\begin{array}{l}\text { Allocation } \\
\text { concealment } \\
\text { (selection bias) }\end{array}$ & Unclear risk & $\begin{array}{l}\text { Allocations were concealed in sealed envelopes which were opened } \\
\text { immediately after delivery }\end{array}$ \\
\hline $\begin{array}{l}\text { Blinding } \\
\text { (performance bias } \\
\text { and detection bias) } \\
\text { All outcomes }\end{array}$ & Unclear risk & $\begin{array}{l}\text { Attempts to blind mothers, staff and outcome assessors were not } \\
\text { mentioned. Mothers would be aware of allocation, staff were also likely } \\
\text { to have been aware of treatment group and may have altered other } \\
\text { aspects of treatment and outcome assessors accompanied the mothers } \\
\text { home from hospital so may well have been aware of group allocation }\end{array}$ \\
\hline $\begin{array}{l}\text { Incomplete } \\
\text { outcome data } \\
\text { (attrition bias) All } \\
\text { outcomes }\end{array}$ & Unclear risk & $\begin{array}{l}40 \text { women. Denominators for longer tem outcomes were not specified } \\
\text { so it is not clear how many women remained available to follow-up at } \\
\text { each data collection point }\end{array}$ \\
\hline $\begin{array}{l}\text { Selective reporting } \\
\text { (reporting bias) }\end{array}$ & Unclear risk & Assessment made from published reports only. \\
\hline Other bias & Unclear risk & $\begin{array}{l}\text { There was some imbalance in the socioeconomic background of women } \\
\text { although this was not consistent across study sites Little information } \\
\text { was provided on study methods. } \\
\text { Women were followed up for } 9 \text { months or } 1 \text { year. Duration of } \\
\text { breastfeeding was an outcome. It is not clear whether any women were } \\
\text { still breastfeeding at the final data collection point. No SDs were } \\
\text { provided for continuous variables so some findings were difficult to } \\
\text { interpret }\end{array}$ \\
\hline
\end{tabular}

\section{Svejda 1980}

\begin{tabular}{ll}
\hline Methods & Randomized controlled trial. \\
\hline Participants & \begin{tabular}{l} 
30 healthy full term infants and their mothers. \\
\hline Interventions
\end{tabular} \\
$\begin{array}{l}\text { 1) Control group = held their wrapped infants briefly }(<5 \text { min }) \text { during transfer, then } 30 \text { min of } \\
\text { contact at feedings every } 4 \text { hours. } 2) \text { Extra contact group }=\text { SSC for } 15 \text { min beginning } 25 \text { min } \\
\text { postbirth, then the gowned mothers held their nude infants for } 45 \text { min in their rooms, } 90 \text { min of } \\
\text { contact every } 4 \text { hours for feedings }\end{array}$ \\
\hline $\begin{array}{l}\text { Videotaped affectionate and proximity - maintaining behavior in interaction with the infant, } \\
\text { affectionate and caretaking behavior during breastfeeding } 36 \text { hours postbirth }\end{array}$ \\
\hline Notes & Study was done with middle-income, primipara in the USA. \\
\hline
\end{tabular}

Cochrane Database Syst Rev. Author manuscript; available in PMC 2014 April 08. 


\begin{tabular}{|c|c|c|}
\hline Bias & Authors' judgement & Support for judgement \\
\hline $\begin{array}{l}\text { Random sequence } \\
\text { generation } \\
\text { (selection bias) }\end{array}$ & Unclear risk & $\begin{array}{l}\text { Very little information about study methods provided. Method of } \\
\text { sequence generation not described }\end{array}$ \\
\hline $\begin{array}{l}\text { Allocation } \\
\text { concealment } \\
\text { (selection bias) }\end{array}$ & Unclear risk & "mothers were randomly assigned". Method not described. \\
\hline $\begin{array}{l}\text { Blinding } \\
\text { (performance bias } \\
\text { and detection bias) } \\
\text { All outcomes }\end{array}$ & Unclear risk & $\begin{array}{l}\text { The intervention was not explained to women. Staff providing care } \\
\text { would be aware of group assignment. There was an attempt to check } \\
\text { that the duration of time nurses spent with women was not greater for } \\
\text { the intervention group. Outcome data were derived from observations } \\
\text { of videotapes with maternal behavior coded by researchers who were } \\
\text { described as being blind to group assignments; inter-rater reliability } \\
\text { was checked }\end{array}$ \\
\hline $\begin{array}{l}\text { Incomplete outcome } \\
\text { data (attrition bias) } \\
\text { All outcomes }\end{array}$ & Low risk & All women were included in the analyses. \\
\hline $\begin{array}{l}\text { Selective reporting } \\
\text { (reporting bias) }\end{array}$ & Unclear risk & $\begin{array}{l}\text { It was not clear how scores from observations were calculated and } \\
\text { whether women could contribute different numbers of observations. }\end{array}$ \\
\hline Other bias & Unclear risk & $\begin{array}{l}\text { It was stated that the } 2 \text { groups were comparable at baseline. Very little } \\
\text { information was provided on study methods }\end{array}$ \\
\hline
\end{tabular}

\section{Syfrett 1996}

\begin{tabular}{|c|c|c|}
\hline Methods & \multicolumn{2}{|c|}{ Randomized controlled trial (computerized minimization technique) } \\
\hline Participants & \multicolumn{2}{|c|}{$\begin{array}{l}8 \text { healthy late preterm infants } 34-36 \text { weeks' gestation, average for GA, Apgars } 7 \text { or more, and their } \\
\text { mothers }\end{array}$} \\
\hline Interventions & \multicolumn{2}{|c|}{$\begin{array}{l}\text { 1) Control group }=24 \text { min of SSC during the first hour postbirth before randomization to radiant } \\
\text { warmer for } 3 \text { hours, double wrapped in open bassinet for } 3 \text { hours then demand feeding and } \\
\text { continuous rooming-in if stable. } 2 \text { ) KC group }=40 \text { min of SSC during the first hour postbirth, } \\
\text { transferred to nursery for admission procedures, then continuous SSC (mean } 37 \text { hours) and } \\
\text { breastfeeding on demand }\end{array}$} \\
\hline Outcomes & \multicolumn{2}{|c|}{$\begin{array}{l}\text { Temperature, temperature variability, breastfeedings/day, bottle-feedings ( } \mathrm{ml} / \text { day), IV fluids (ml/ } \\
\text { day), weight loss }(\mathrm{g} / \mathrm{hr}) \text {, birthweight lost }(\%) \text {, number of heel sticks, length of stay (total days), } \\
\text { breastfeeding duration }\end{array}$} \\
\hline Notes & \multicolumn{2}{|c|}{ Study was done in the USA. All nursing care in the $\mathrm{KC}$ group was done by the researchers } \\
\hline \multicolumn{3}{|l|}{ Risk of bias } \\
\hline Bias & Authors' judgement & Support for judgement \\
\hline $\begin{array}{l}\text { Random } \\
\text { sequence } \\
\text { generation } \\
\text { (selection bias) }\end{array}$ & Low risk & $\begin{array}{l}\text { "random assignment.... was done using the minimization technique". The } \\
\text { randomization sequence took account of a relatively large number of } \\
\text { stratifying variable and the eventual sample size was only } 8 \text { women. } \\
\text { (Stratification by GA, race, sex, induction or augmentation, intrapartum } \\
\text { analgesia/anesthesia, maternal magnesium sulphate and previous breast } \\
\text { feeding experience }\end{array}$ \\
\hline $\begin{array}{l}\text { Allocation } \\
\text { concealment } \\
\text { (selection bias) }\end{array}$ & Low risk & $\begin{array}{l}\text { Randomization was carried out } 1 \text { hour after birth at admission to the } \\
\text { newborn nursery. } 1 \text { of the investigators revealed the next allocation in the } \\
\text { randomization sequence }\end{array}$ \\
\hline $\begin{array}{l}\text { Blinding } \\
\text { (performance } \\
\text { bias and } \\
\text { detection bias) } \\
\text { All outcomes }\end{array}$ & High risk & $\begin{array}{l}\text { This study was at high risk of bias due to the lack of blinding. It was } \\
\text { stated that control group women may have been dissatisfied knowing that } \\
\text { the intervention group were given more infant contact. The control group } \\
\text { and the intervention group were cared for by different staff. The control } \\
\text { group received routine care while the intervention groups received special } \\
\text { care from the investigators - which included advice on breastfeeding and } 5 \\
\text { min pager access to staff as well as advice on SSC. The same nurse } \\
\text { investigators also collected outcome data for the SSC group }\end{array}$ \\
\hline
\end{tabular}

Cochrane Database Syst Rev. Author manuscript; available in PMC 2014 April 08. 


\begin{tabular}{|c|c|c|}
\hline $\begin{array}{l}\text { Incomplete } \\
\text { outcome data } \\
\text { (attrition bias) } \\
\text { All outcomes }\end{array}$ & Unclear risk & $\begin{array}{l}8 \text { infants were involved in this study and all but } 1 \text { were followed up for a } \\
\text { year }\end{array}$ \\
\hline $\begin{array}{l}\text { Selective } \\
\text { reporting } \\
\text { (reporting bias) }\end{array}$ & Unclear risk & $\begin{array}{l}\text { Assessment from unpublished thesis. The recruitment, intervention and } \\
\text { data collection were carried out by the same (unblinded) investigators }\end{array}$ \\
\hline Other bias & High risk & $\begin{array}{l}\text { This study had a very small sample size that was recruited at times } \\
\text { convenient to the investigators over a } 10 \text { month period. It is not clear that } \\
\text { the sample was representative of the population from which it was drawn. } \\
\text { The intervention was delivered by the investigators and included changes } \\
\text { to aspects of care other than SSC (e.g. breastfeeding advice). It is difficult } \\
\text { to separate the effects of the intervention from the effects of other } \\
\text { elements within the package of care }\end{array}$ \\
\hline
\end{tabular}

\section{Thomson 1979}

\begin{tabular}{|c|c|c|}
\hline Methods & \multicolumn{2}{|c|}{ Randomized controlled trial. } \\
\hline Participants & \multicolumn{2}{|c|}{34 healthy full term infants and their mothers. } \\
\hline Interventions & \multicolumn{2}{|c|}{$\begin{array}{l}\text { 1) Control group = held their wrapped infants briefly }(<5 \mathrm{~min}) \text {, subsequent contact at } 12-24 \\
\text { hours postbirth, then contact every } 4 \text { hours for feedings during the day. } 2 \text { ) Early contact group }= \\
\text { held infant in SSC for } 15-20 \text { min starting } 15-30 \text { min postbirth. Mothers were encouraged to } \\
\text { breastfeed, subsequent contact at } 12-24 \text { hours postbirth, then contact every } 4 \text { hours for feedings } \\
\text { during the day }\end{array}$} \\
\hline Outcomes & \multicolumn{2}{|c|}{$\begin{array}{l}\text { 1) Happy maternal reaction to birth. 2) Breastfeeding at hospital discharge. 3) Successful } \\
\text { breastfeeding } 2 \text { months postbirth }\end{array}$} \\
\hline Notes & \multicolumn{2}{|c|}{ Study was done with married, primipara in Canada. } \\
\hline \multicolumn{3}{|l|}{ Risk of bias } \\
\hline Bias & Authors' judgement & Support for judgement \\
\hline $\begin{array}{l}\text { Random sequence } \\
\text { generation } \\
\text { (selection bias) }\end{array}$ & Unclear risk & $\begin{array}{l}\text { The randomization process was not described "the observer randomly } \\
\text { assigned the mother-infant pair to a control or to an early-contact } \\
\text { group" }\end{array}$ \\
\hline $\begin{array}{l}\text { Allocation } \\
\text { concealment } \\
\text { (selection bias) }\end{array}$ & Unclear risk & The process was not described. \\
\hline $\begin{array}{l}\text { Blinding } \\
\text { (performance bias } \\
\text { and detection bias) } \\
\text { All outcomes }\end{array}$ & Unclear risk & $\begin{array}{l}\text { Women were not told about the study intervention but told that the } \\
\text { study was about infant nutrition. It was stated that only delivery room } \\
\text { staff caring for women were aware of group assignments, staff } \\
\text { thereafter were not made aware of allocation. The person carrying out } \\
\text { the randomization also collected delivery room data, but staff } \\
\text { collecting other outcome data were described as blind although women } \\
\text { may have revealed group status }\end{array}$ \\
\hline $\begin{array}{l}\text { Incomplete outcome } \\
\text { data (attrition bias) } \\
\text { All outcomes }\end{array}$ & Unclear risk & 34 women recruited. 4 lost to follow up. \\
\hline $\begin{array}{l}\text { Selective reporting } \\
\text { (reporting bias) }\end{array}$ & Unclear risk & $\begin{array}{l}1 \text { outcome "Happy maternal reaction to the infant" was assessed by an } \\
\text { observer that had carried out the randomization and remained in the } \\
\text { delivery room during the intervention. }\end{array}$ \\
\hline Other bias & Unclear risk & Little information on study methods was provided. \\
\hline
\end{tabular}

Vaidya 2005

\begin{tabular}{ll}
\hline Methods & Randomized controlled trial. \\
\hline
\end{tabular}




\begin{tabular}{|c|c|c|}
\hline Participants & \multicolumn{2}{|c|}{110 healthy full term infants and their mothers. } \\
\hline Interventions & \multicolumn{2}{|c|}{$\begin{array}{l}\text { 1) SSC group = the naked infant was placed on the mother's naked chest for } 10-15 \text { min within } 1 \\
\text { hour of birth. 2) Control group = after immediate newborn care the infants were dressed and } \\
\text { given to their mothers or visitors. Both groups were encouraged to initiate breastfeeding }\end{array}$} \\
\hline Outcomes & \multicolumn{2}{|c|}{$\begin{array}{l}\text { Exclusive breastfeeding up to 2-4 and 4- } 6 \text { months postbirth, started other feedings before } 2 \\
\text { months of age }\end{array}$} \\
\hline Notes & \multicolumn{2}{|c|}{ Study was done in Kathmandu, Nepal. } \\
\hline \multicolumn{3}{|l|}{ Risk of bias } \\
\hline Bias & Authors' judgement & Support for judgement \\
\hline $\begin{array}{l}\text { Random sequence } \\
\text { generation } \\
\text { (selection bias) }\end{array}$ & Unclear risk & $\begin{array}{l}\text { "...some mother-baby pairs were selected randomly and after taking } \\
\text { verbal consent were allowed to have skin-to-skin contact.... In the } \\
\text { remaining control group, babies after immediate newborn care were } \\
\text { dressed as usual" }\end{array}$ \\
\hline $\begin{array}{l}\text { Allocation } \\
\text { concealment } \\
\text { (selection bias) }\end{array}$ & Unclear risk & $\begin{array}{l}\text { There was little information about study methods and the method of } \\
\text { randomization was not described clearly }\end{array}$ \\
\hline $\begin{array}{l}\text { Blinding } \\
\text { (performance bias } \\
\text { and detection bias) } \\
\text { All outcomes }\end{array}$ & Unclear risk & $\begin{array}{l}\text { Blinding was not mentioned, it is likely that all groups were aware of } \\
\text { group assignment }\end{array}$ \\
\hline $\begin{array}{l}\text { Incomplete } \\
\text { outcome data } \\
\text { (attrition bias) All } \\
\text { outcomes }\end{array}$ & High risk & $\begin{array}{l}\text { It was stated that } 110 \text { women were included in the study and } 92 \text { were } \\
\text { followed up, the reasons for loss to follow up were not stated. It was not } \\
\text { clear where the numbers of women lost to follow up were the same in } \\
\text { the control and intervention groups. There was some discrepancy in } \\
\text { numbers in different tables; in a table setting out duration of breast } \\
\text { feeding by mode of delivery only } 60 \text { women were accounted for }\end{array}$ \\
\hline $\begin{array}{l}\text { Selective reporting } \\
\text { (reporting bias) }\end{array}$ & Unclear risk & Assessment from published study report. \\
\hline Other bias & Unclear risk & $\begin{array}{l}\text { The sample was not described and it was not clear whether the } 2 \text { groups } \\
\text { were balanced in terms of parity, mode of delivery, and other } \\
\text { potentially important variables } \\
\text { Very little information about study methods was provided. }\end{array}$ \\
\hline
\end{tabular}

Villalon 1993

\begin{tabular}{ll}
\hline Methods & Randomized controlled trial. \\
\hline Participants & 119 healthy full term infants and their mothers. \\
\hline Interventions & $\begin{array}{l}\text { SSC Group = babies were placed SSC on their mothers immediately postbirth, then dried and } \\
\text { given medications. Diapered infants were then placed between their mother's breasts and covered } \\
\text { with a blanket. Breastfeeding was initiated or attempted. Babies stayed in contact with their } \\
\text { mothers for most of the following 4 hours. Control group = babies were dried, given medications, } \\
\text { clothed and taken to the nursery for 4 hours }\end{array}$ \\
\hline $\begin{array}{l}\text { Butcomes } \\
\text { confidence, temperature, HR, respiratory rate at 1,2,3 and 4 hours postbirth in a subset of 92 } \\
\text { infants }\end{array}$ & $\begin{array}{l}\text { Study was done in Coyhaique, Chile. All mothers were Hispanic with mixed parity and education. } \\
\text { Temperature, HR and respiratory rate data were obtained from a subset of 96 infants }\end{array}$ \\
\hline $\begin{array}{l}\text { Notes } \\
\text { Risk } \text { of bias }\end{array}$ & Authors' judgement \\
\hline $\begin{array}{l}\text { Bias } \\
\begin{array}{l}\text { Requence } \\
\text { generation } \\
\text { (selection bias })\end{array}\end{array}$ & \begin{tabular}{l} 
Unclear risk \\
\hline
\end{tabular} \\
\hline
\end{tabular}

Cochrane Database Syst Rev. Author manuscript; available in PMC 2014 April 08. 


\begin{tabular}{|c|c|c|}
\hline $\begin{array}{l}\text { Allocation } \\
\text { concealment } \\
\text { (selection bias) }\end{array}$ & Unclear risk & The randomization process was not described. \\
\hline $\begin{array}{l}\text { Blinding } \\
\text { (performance } \\
\text { bias and detection } \\
\text { bias) } \\
\text { All outcomes }\end{array}$ & Unclear risk & $\begin{array}{l}\text { No blinding of women, clinical staff or observers and } \\
\text { outcomes susceptible to response and observer bias }\end{array}$ \\
\hline $\begin{array}{l}\text { Incomplete } \\
\text { outcome data } \\
\text { (attrition bias) All } \\
\text { outcomes }\end{array}$ & High risk & $\begin{array}{l}\text { Describe any loss of participants to follow-up at each } \\
\text { data collection point: } 119 \text { women randomized. It } \\
\text { appeared that outcome data were available for all } \\
\text { women at } 24 \text { hours. However, at } 14 \text { days data were } \\
\text { only available for } 65(54 \%) \text { of the randomized sample } \\
\text { (loss was balanced across groups). There was no ITT } \\
\text { analysis for outcomes at } 14 \text { days. }\end{array}$ \\
\hline $\begin{array}{l}\text { Selective } \\
\text { reporting } \\
\text { (reporting bias) }\end{array}$ & Unclear risk & $\begin{array}{l}\text { Assessment made from translation notes from } \\
\text { published article (protocol not available). }\end{array}$ \\
\hline Other bias & Unclear risk & $\begin{array}{l}\text { Baseline imbalance not apparent. } \\
\text { Other: risk of bias assessment from translation notes. }\end{array}$ \\
\hline
\end{tabular}

BAT: Breastfeeding Assessment Tool

BPM: beats per minute

GA: gestational age

HR: heart rate

IBFAT: Infant Breastfeeding Assessment Tool

IBS: Index of breastfeeding status

ITT: intention-to-treat

IV: intravenous

$\mathrm{KC}$ : kangaroo care

M: mean

min.: minutes

MPI: Mother preterm infant interaction

NICU: neonatal intensive care unit

NIMS: Nursing Intervention to Minimize Maternal-Infant Separation

PACU: Post-Anesthesia Care Unit

PCERA: Parent-Child Early Relational Assessment

q3hr: every 3 hours

SAT: saturation

SCRIP: stability of the cardio-respiratory system

SD: standard deviation

SE: standard error

SSC: skin-to-skin contact

\section{Characteristics of excluded studies [ordered by study ID]}

\begin{tabular}{ll}
\hline Study & Reason for exclusion \\
\hline Abdel Razek 2009 & $\begin{array}{l}\text { This quasi-experimental study was conducted in 2 maternal and child health centers in Jordan. } \\
\text { The study was conducted on infants receiving immunization injections during their first year of } \\
\text { life }\end{array}$ \\
\hline
\end{tabular}


Ali 1981 No mention was made regarding whether the early maternal-infant contact was skin-to-skin

\begin{tabular}{|c|c|}
\hline Anisfeld 1983 & This study was a quasi-randomized trial. Group assignment was by day of the week \\
\hline Castral 2008 & $\begin{array}{l}\text { This study took place with stable preterm infants (at least } 30 \text { weeks' GA) during a heel lance } \\
\text { procedure. All of the infants were located in the intermediary neonatal care unit; } 62 \% \text { of these } \\
\text { infants had been transferred from the NICU. Mean birthweight was } 1748.8 \mathrm{~g} \text { for the SSC } \\
\text { infants and } 1846.2 \mathrm{~g} \text { for the control group }\end{array}$ \\
\hline Cattaneo 1998 & $\begin{array}{l}\text { This was not a study of early KMC. The median age of enrolment in the study was } 10 \text { days } \\
\text { postbirth for KMC infants and } 8 \text { days postbirth for CMC infants }\end{array}$ \\
\hline Christensson 1998 & $\begin{array}{l}\text { Infants in the control and intervention groups were hypothermic and admitted to the NICU } \\
\text { before the study began }\end{array}$ \\
\hline Darmstadt 2006 & $\begin{array}{l}\text { This was not a study of early SSC. The intervention was a community mobilization and } \\
\text { behavior change communication program aimed at increasing the acceptability of skin-to-skin } \\
\text { care for mothers who deliver at home in rural Uttar Pradesch, India }\end{array}$ \\
\hline Durand 1997 & $\begin{array}{l}\text { Not a randomized trial, participants self-selected into the experimental or control group based } \\
\text { on their desire to breast or bottle feed }\end{array}$ \\
\hline Erlandsson 2007 & This was a study of skin-to-skin care with the father after cesarean birth \\
\hline Feldman 2003 & $\begin{array}{l}\text { Study was not an RCT. KC infants were recruited at } 1 \text { hospital and control infants from another } \\
\text { hospital. Infants were cared for concurrently at the } 2 \text { hospitals. Families were recruited to } \\
\text { participate several days to several weeks postbirth. All infants were in the NICU. Mean GA - } \\
30.65 \text { weeks }\end{array}$ \\
\hline Ferber 2008 & This study was conducted on preterm infants in the NICU. \\
\hline Gardner 1979 & $\begin{array}{l}\text { No information was provided about whether infants were randomized to SSC (group 1) or } \\
\text { standard care in a Kreisselman warmer bed (group 2). No means and standard deviations were } \\
\text { provided for the outcome variable rectal temperature at } 17 \text { min postbirth }\end{array}$ \\
\hline Gathwala 2008 & $\begin{array}{l}\text { This was a study of KMC for preterm and low birthweight infants in the NICU. KMC was } \\
\text { initiated at a mean age of } 1.72+0.45 \text { days of age. }\end{array}$ \\
\hline Gomes-Pedro 1984 & The early contact in the intervention group was not skin-to-skin \\
\hline Gray 2000 & $\begin{array}{l}\text { This was not a study of early SSC. Infants were between } 33 \text { and } 55 \text { hours postnatal age at study } \\
\text { entry }\end{array}$ \\
\hline Gray 2002 & Infants were between 40 and 44 hours postnatal age at study entry \\
\hline Grossman 1981 & $\begin{array}{l}\text { A questionable quasi-randomization procedure was used - the experimental treatment and time } \\
\text { are confounded. No mention was made regarding whether the early contact was skin-to-skin }\end{array}$ \\
\hline Hill 1979 & $\begin{array}{l}\text { The study was described as "experimental" with } 50 \text { infants per group but the author does not } \\
\text { state that infants were randomized to groups. Study compared swaddled holding (not SSC) by } \\
\text { the mother or father to a heated transporter }\end{array}$ \\
\hline Ibe 2004 & $\begin{array}{l}\text { In the KMC group, infants were dressed in cotton vests and caps and placed between their } \\
\text { mother's breasts. The study was not an RCT - infants served as their own controls and } \\
\text { alternated between KMC and incubator care. Infants were recruited between } 24 \text { hours to } 30 \\
\text { days of age }\end{array}$ \\
\hline Johanson 1992 & $\begin{array}{l}\text { In the } \mathrm{KC} \text { group "the baby was placed under the mother's clothes on her chest. If the clothing } \\
\text { alone was considered insufficient, the baby was swaddled in } 1 \text { of the labor room blankets and } \\
\text { then kept immediately against the mother" (p 860). The full term data were not reported } \\
\text { separately; instead they were combined with preterm data in the analyses }\end{array}$ \\
\hline Johnson 1976 & No mention was made regarding whether the early maternal-infant contact was skin-to-skin \\
\hline Kadam 2005 & $\begin{array}{l}\text { Study was conducted in a level } 3 \mathrm{NICU} \text { in Mumbai, mean age of the infants at enrolment was } \\
3.2 \text { days, range 1-8 days, mean GA of the KC infants was } 33.3 \text { weeks }\end{array}$ \\
\hline Karlsson 1996 & Not a randomized trial; a descriptive study. \\
\hline Klaus 1972 & The early contact in the intervention group was not skin-to-skin \\
\hline Kontos 1978 & $\begin{array}{l}\text { This study was not a randomized trial. Mothers who chose to room in and those who did not } \\
\text { were alternately assigned to early SSC or usual care. No means or standard deviations were } \\
\text { provided for the attachment summary score or individual attachment behaviors }\end{array}$ \\
\hline Lindenberg 1990 & No mention was made regarding whether the early maternal-infant contact was skin-to-skin \\
\hline
\end{tabular}


Ludington-Hoe 2004 This was not a study of early SSC. SSC began M =17.82 days postbirth. All infants were in the NICU

Ludington-Hoe 2006 This study was conducted on preterm infants (mean GA $30.8+1.4$ weeks SSC group, $30.8+$ 1.1 weeks control group) in the NICU. Mean age at the time of the study was $11.6+5.1$ days SSC group, $12.0+12$ days control group.

\begin{tabular}{|c|c|}
\hline Marin 2010 & $\begin{array}{l}\text { The pediatricians, rather than the mothers, were randomly assigned to whether or not they } \\
\text { would provide early SSC immediately postbirth }\end{array}$ \\
\hline Mikiel-Kostyra 2002 & $\begin{array}{l}\text { In this study infants were not randomly assigned to groups. Information on the care of } 11,973 \\
\text { newborn infants from birth to hospital discharge was collected in } 427 \text { maternity wards using a } \\
\text { standardized questionnaire. Then a subset of } 9612 \text { newborns was created. Then } 1923 \\
\text { participants ( } 20 \% \text { of the subset) were randomly selected by systematic sampling of every } 5 \text { th } \\
\text { case to complete a follow-up questionnaire }\end{array}$ \\
\hline Miles 2006 & This study was conducted on preterm infants < 32 weeks' GA in 2 NICUs \\
\hline Nagai 2010 & $\begin{array}{l}\text { This study was excluded as both groups received SSC in a setting where SSC had already been } \\
\text { introduced as standard care; earlier and later SSC were compared. It was intended that the } \\
\text { "early" SSC group would begin SSC within } 24 \text { hours of the "later" SSC group. In fact there was } \\
\text { considerable overlap between the } 2 \text { groups and results are difficult to interpret }\end{array}$ \\
\hline Neu 2010 & $\begin{array}{l}\text { This was not a study of early SSC. It is a study of preterm birth (mean GA at birth } 33 \text { weeks) in } \\
\text { NICU. Women were recruited to participate within } 1 \text { month of the birth }\end{array}$ \\
\hline Ohgi 2002 & $\begin{array}{l}\text { This was a non-randomized intervention study of infants who received } \mathrm{KC} \text { compared to a } \\
\text { historical comparison group of infants who did not receive } \mathrm{KC} \text {. Also KC was initiated 1-3 days } \\
\text { postbirth }\end{array}$ \\
\hline Okan 2010 & $\begin{array}{l}\text { This was not a study of early SSC. The infant's mean postnatal age at the time of the } \\
\text { intervention hypothesized to decrease pain from a heel lance procedure was } 33.1+5 \text { hours } \\
\text { postbirth. }\end{array}$ \\
\hline Ottaviano 1979 & No mention was made regarding whether the early maternal-infant contact was skin-to-skin \\
\hline Ramanathan 2001 & This study took place in the NICU. Mean GA of the infants was 31.5 weeks \\
\hline Roberts 2000 & $\begin{array}{l}\text { This was not a study of early KMC. SSC was started median }=11.8 \text { days postbirth. Median GA } \\
\text { was } 30.4 \text { weeks in the KMC group; } 30.9 \text { weeks in the control group }\end{array}$ \\
\hline Rojas 2001 & This was a study of preterm infants who were $<1500$ grams. \\
\hline Salariya 1978 & No mention was made regarding whether the early maternal-infant contact was skin-to-skin \\
\hline Sloan 2008 & $\begin{array}{l}\text { This was a study of community-based KMC in rural Bangladesh. Half of } 42 \text { unions in } 2 \\
\text { Bangladesh divisions were randomly assigned to community-based KMC }\end{array}$ \\
\hline Suman 2008 & This study enrolled low birthweight infants (< 2000 grams) in a Level III NICU \\
\hline Taylor 1979 & The early contact in the intervention group was not skin-to-skin \\
\hline Taylor 1985 & The early contact in the intervention groups was not skin-to-skin \\
\hline Taylor 1986 & $\begin{array}{l}\text { Not a randomized trial, a descriptive study. The early contact in the intervention group was not } \\
\text { skin-to-skin }\end{array}$ \\
\hline Tessier 2009 & $\begin{array}{l}\text { This study was conducted with preterm infants (mean GA KMC group } 33.6+2.5 \text { weeks, } \\
\text { control group } 33.9+2.7 \text { weeks). The infants were all }<2000 \text { grams. The median age for study } \\
\text { eligibility was } 4 \text { days in the KMC group and } 3 \text { days in the control group }\end{array}$ \\
\hline Thukral 2010 & $\begin{array}{l}\text { Not enough information was provided in the research abstract to be able to evaluate the study } \\
\text { for methodological quality }\end{array}$ \\
\hline Velandia 2010 & $\begin{array}{l}\text { In this study all infants received early SSC; following cesarean SSC with mothers was } \\
\text { compared with SSC with fathers }\end{array}$ \\
\hline Wimmer 1982 & No standard deviations provided for breastfeeding duration. \\
\hline Worku 2005 & $\begin{array}{l}\text { This was not a study of late preterm infants. The mean GA was } 32.45 \text { weeks KMC and } 31.59 \\
\text { weeks CMC infants. The mean birthweight was } 1514.8 \mathrm{~g} \text { (range } 1000-1900 \mathrm{~g} \text { ) for KMC and } \\
1471.8 \mathrm{~g} \text { (range } 930-1900 \mathrm{~g} \text { ) for CMC infants. } 58 \% \text { of the KMC and } 52 \% \text { of CMC infants were } \\
\text { on IV fluids and } 34 \% \text { of the KMC and } 37 \% \text { of the CMC infants were on oxygen through } \\
\text { nasopharyngeal catheter. In addition, these infants experienced significant morbidity; } 22.5 \% \text { of } \\
\text { the KMC infants and } 38 \% \text { of the CMC infants died during the study period. Infants were } \\
\text { randomly assigned using a list of random numbers to conventional care ( }=61 \text {, overhead lamp } \\
\text { warmers or a heated room, oxygen therapy, breast, tube, cup or mixed feedings) or early KMC } \\
\text { (n=62) starting during the first } 24 \text { hours of life (mean age } 10 \mathrm{~h} \mathrm{KMC,} 9.8 \mathrm{CMC} \text { ) }\end{array}$ \\
\hline
\end{tabular}


CMC: conventional method of care

GA: gestational age

h: hour

KC: kangaroo care

KMC: kangaroo mother care

min: minutes

NICU: neonatal intensive care unit

RCT: randomized controlled trial

SSC: skin-to-skin contact

\section{Characteristics of ongoing studies [ordered by study ID]}

Keshavarz 2010

\begin{tabular}{ll}
\hline Trial name or title & Skin to skin contact with or without music and maternal state anxiety \\
\hline Methods & Randomized (single blind) trial. \\
\hline Participants & $\begin{array}{l}\text { Healthy Iranian women 20-40 years with term, singleton pregnancy with cesarean section under } \\
\text { spinal anesthesia. No history of neonatal death }\end{array}$ \\
\hline Interventions & Skin to skin contact for 30 minutes with music. \\
\hline Outcomes & Maternal state anxiety. \\
\hline Starting date & July 2009. \\
\hline Contact information & Maryam Keshavarz keshavarz@iums.ac.ir m-keshir@yahoo.com \\
\hline Notes & Information from a trial registration. \\
\hline
\end{tabular}

\section{DATA AND ANALYSES}

\section{Comparison 1}

Skin-to-skin versus standard contact healthy infants

\begin{tabular}{|c|c|c|c|c|}
\hline $\begin{array}{l}\text { Outcome or } \\
\text { subgroup title }\end{array}$ & No. of studies & No. of participants & Statistical method & Effect size \\
\hline $\begin{array}{l}1 \text { Breastfeeding } 1 \\
\text { month to } 4 \text { months } \\
\text { postbirth }\end{array}$ & 13 & 702 & $\begin{array}{l}\text { Risk Ratio (M-H, } \\
\text { Random, 95\% CI) }\end{array}$ & $1.27[1.06,1.53]$ \\
\hline $\begin{array}{l}2 \text { Duration of } \\
\text { breastfeeding in days }\end{array}$ & 7 & 324 & $\begin{array}{l}\text { Mean Difference (IV, } \\
\text { Random, 95\% CI) }\end{array}$ & $42.55[-1.69,86.79]$ \\
\hline $\begin{array}{l}3 \text { SCRIP score first } 6 \\
\text { hours postbirth }\end{array}$ & 1 & 31 & $\begin{array}{l}\text { Mean Difference (IV, } \\
\text { Fixed, 95\% CI) }\end{array}$ & $2.88[0.53,5.23]$ \\
\hline $\begin{array}{l}4 \text { SCRIP score first } 6 \\
\text { hours in newborns } \\
\text { below } 1800 \mathrm{~g} \\
\text { birthweight }\end{array}$ & 1 & 13 & $\begin{array}{l}\text { Mean Difference (IV, } \\
\text { Fixed, 95\% CI) }\end{array}$ & $4.92[-1.67,11.51]$ \\
\hline $\begin{array}{l}5 \text { Blood glucose mg/ } \\
\mathrm{dL} \text { and mmol/L at } \\
75-90 \text { minutes } \\
\text { postbirth }\end{array}$ & 2 & 94 & $\begin{array}{l}\text { Mean Difference (IV, } \\
\text { Fixed, 95\% CI) }\end{array}$ & $10.56[8.40,12.72]$ \\
\hline $\begin{array}{l}6 \text { Infant axillary } \\
\text { temperature } 90 \\
\text { minutes to } 2 \text { hours } \\
\text { postbirth }\end{array}$ & 3 & & $\begin{array}{l}\text { Mean Difference (IV, } \\
\text { Fixed, 95\% CI) }\end{array}$ & Totals not selected \\
\hline
\end{tabular}




\begin{tabular}{|c|c|c|c|c|}
\hline $\begin{array}{l}\text { Outcome or } \\
\text { subgroup title }\end{array}$ & No. of studies & No. of participants & Statistical method & Effect size \\
\hline $\begin{array}{l}7 \text { Exclusive } \\
\text { breastfeeding at } \\
\text { hospital discharge }\end{array}$ & 2 & 57 & $\begin{array}{l}\text { Risk Ratio (M-H, Fixed, } \\
95 \% \text { CI) }\end{array}$ & $0.99[0.66,1.47]$ \\
\hline $\begin{array}{l}8 \text { Breastfeeding status } \\
\text { day } 28 \text { to } 1 \text { month } \\
\text { postbirth }\end{array}$ & 3 & 245 & $\begin{array}{l}\text { Mean Difference (IV, } \\
\text { Random, 95\% CI) }\end{array}$ & $0.86[-0.73,2.44]$ \\
\hline $\begin{array}{l}9 \text { Exclusive } \\
\text { breastfeeding up to } \\
3-6 \text { months postbirth }\end{array}$ & 3 & 149 & $\begin{array}{l}\text { Risk Ratio (M-H, Fixed, } \\
95 \% \text { CI) }\end{array}$ & $1.97[1.37,2.83]$ \\
\hline $\begin{array}{l}10 \text { Breastfeeding } 1 \\
\text { year postbirth }\end{array}$ & 2 & 62 & $\begin{array}{l}\text { Risk Ratio (M-H, Fixed, } \\
95 \% \text { CI) }\end{array}$ & $6.19[0.82,46.78]$ \\
\hline $\begin{array}{l}11 \text { Success of the first } \\
\text { breastfeeding (IBFAT } \\
\text { score) }\end{array}$ & 2 & 54 & $\begin{array}{l}\text { Mean Difference (IV, } \\
\text { Fixed, 95\% CI) }\end{array}$ & $1.79[0.24,3.35]$ \\
\hline $\begin{array}{l}12 \text { Successful first } \\
\text { breastfeeding (IBFAT } \\
\text { score } 10-12 \text { or BAT } \\
\text { score } 8-12 \text { ) }\end{array}$ & 3 & 315 & $\begin{array}{l}\text { Risk Ratio (M-H, } \\
\text { Random, 95\% CI) }\end{array}$ & $1.36[0.95,1.95]$ \\
\hline $\begin{array}{l}13 \text { Suckled during the } \\
\text { first } 2 \text { hours postbirth }\end{array}$ & 1 & 88 & $\begin{array}{l}\text { Risk Ratio (M-H, Fixed, } \\
95 \% \text { CI) }\end{array}$ & $1.06[0.83,1.35]$ \\
\hline $\begin{array}{l}14 \text { Mean variation in } \\
\text { maternal breast temp. } \\
30-120 \text { minutes } \\
\text { postbirth }\end{array}$ & 1 & 132 & $\begin{array}{l}\text { Mean Difference (IV, } \\
\text { Fixed, 95\% CI) }\end{array}$ & $0.60[0.34,0.86]$ \\
\hline $\begin{array}{l}15 \text { Breast } \\
\text { engorgement - pain, } \\
\text { tension, hardness } 3 \\
\text { days postbirth }\end{array}$ & 2 & 131 & $\begin{array}{l}\text { Std. Mean Difference } \\
\text { (IV, Fixed, 95\% CI) }\end{array}$ & $-0.41[-0.76,-0.06]$ \\
\hline $\begin{array}{l}16 \text { Heart rate } 75 \\
\text { minutes to } 2 \text { hours } \\
\text { postbirth }\end{array}$ & 3 & 183 & $\begin{array}{l}\text { Mean Difference (IV, } \\
\text { Random, 95\% CI) }\end{array}$ & $-3.05[-7.84,1.75]$ \\
\hline $\begin{array}{l}17 \text { Respiratory rate } 75 \\
\text { minutes - } 2 \text { hours } \\
\text { postbirth }\end{array}$ & 4 & 215 & $\begin{array}{l}\text { Mean Difference (IV, } \\
\text { Random, 95\% CI) }\end{array}$ & $-3.12[-6.61,0.37]$ \\
\hline $\begin{array}{l}18 \text { Infant did not } \\
\text { exceed parameters for } \\
\text { stability }\end{array}$ & 1 & 31 & $\begin{array}{l}\text { Risk Ratio (M-H, Fixed, } \\
95 \% \text { CI) }\end{array}$ & $10.83[1.63,72.02]$ \\
\hline $\begin{array}{l}19 \text { Transferred to the } \\
\text { neonatal intensive } \\
\text { care unit }\end{array}$ & 1 & 31 & $\begin{array}{l}\text { Risk Ratio (M-H, Fixed, } \\
95 \% \text { CI) }\end{array}$ & $1.44[0.15,14.29]$ \\
\hline $\begin{array}{l}20 \text { Infant body weight } \\
\text { change (grams) day } \\
14 \text { postbirth }\end{array}$ & 2 & 43 & $\begin{array}{l}\text { Mean Difference (IV, } \\
\text { Fixed, 95\% CI) }\end{array}$ & $-6.00[-175.60,159$ \\
\hline $\begin{array}{l}21 \text { Infant weight gain } \\
\text { per kilogram per day } \\
\text { (in grams) }\end{array}$ & 0 & 0 & $\begin{array}{l}\text { Mean Difference (IV, } \\
\text { Fixed, 95\% CI) }\end{array}$ & $0.0[0.0,0.0]$ \\
\hline $\begin{array}{l}22 \text { Infant hospital } \\
\text { length of stay in hours }\end{array}$ & 2 & 42 & $\begin{array}{l}\text { Mean Difference (IV, } \\
\text { Random, 95\% CI) }\end{array}$ & $-95.30[-368.50,177.89]$ \\
\hline $\begin{array}{l}23 \text { Not crying for }>1 \\
\text { minute during } 90 \\
\text { minutes }\end{array}$ & 1 & 29 & $\begin{array}{l}\text { Risk Ratio (M-H, Fixed, } \\
95 \% \text { CI) }\end{array}$ & $12.86[1.91,86.44]$ \\
\hline $\begin{array}{l}24 \text { Amount of crying } \\
\text { in minutes during a } \\
75 \text {-minute observation } \\
\text { period }\end{array}$ & 1 & 44 & $\begin{array}{l}\text { Mean Difference (IV, } \\
\text { Fixed, 95\% CI) }\end{array}$ & $-8.01[-8.98,-7.04]$ \\
\hline $\begin{array}{l}25 \text { PCERA Maternal } \\
\text { positive affective } \\
\text { involvement and }\end{array}$ & 1 & 61 & $\begin{array}{l}\text { Mean Difference (IV, } \\
\text { Fixed, 95\% CI) }\end{array}$ & $1.90[-1.14,4.94]$ \\
\hline
\end{tabular}




\begin{tabular}{|c|c|c|c|c|}
\hline $\begin{array}{l}\text { Outcome or } \\
\text { subgroup title }\end{array}$ & No. of studies & No. of participants & Statistical method & Effect size \\
\hline \multicolumn{5}{|l|}{$\begin{array}{l}\text { responsiveness } 12 \\
\text { months postbirth }\end{array}$} \\
\hline $\begin{array}{l}26 \text { PCERA Dydadic } \\
\text { mutuality and } \\
\text { reciprocity } 12 \text { months } \\
\text { postbirth }\end{array}$ & 1 & 61 & $\begin{array}{l}\text { Mean Difference (IV, } \\
\text { Fixed, 95\% CI) }\end{array}$ & $1.30[0.24,2.36]$ \\
\hline $\begin{array}{l}27 \text { Maternal pain } 4 \\
\text { hours postcesarean } \\
\text { birth }\end{array}$ & 1 & 35 & $\begin{array}{l}\text { Mean Difference (IV, } \\
\text { Fixed, 95\% CI) }\end{array}$ & $-1.38[-2.79,0.03]$ \\
\hline $\begin{array}{l}28 \text { Mother's most } \\
\text { certain preference for } \\
\text { same postdelivery } \\
\text { care in the future }\end{array}$ & 1 & 199 & $\begin{array}{l}\text { Risk Ratio (M-H, Fixed, } \\
95 \% \text { CI) }\end{array}$ & $2.82[2.08,3.82]$ \\
\hline $\begin{array}{l}29 \text { Maternal state } \\
\text { anxiety day } 3 \\
\text { postbirth }\end{array}$ & 1 & 56 & $\begin{array}{l}\text { Mean Difference (IV, } \\
\text { Fixed, 95\% CI) }\end{array}$ & $-5.00[-9.00,1.00]$ \\
\hline $\begin{array}{l}30 \text { Maternal parenting } \\
\text { confidence at } 1 \text { month } \\
\text { postbirth }\end{array}$ & 1 & 20 & $\begin{array}{l}\text { Mean Difference (IV, } \\
\text { Fixed, 95\% CI) }\end{array}$ & $5.60[-6.24,17.44]$ \\
\hline $\begin{array}{l}31 \text { Breastfeeding } 1 \\
\text { month to } 4 \text { months } \\
\text { post birth: Sensitivity } \\
\text { analysis }\end{array}$ & 12 & 642 & $\begin{array}{l}\text { Risk Ratio (M-H, } \\
\text { Random, 95\% CI) }\end{array}$ & $1.31[1.16,1.48]$ \\
\hline $\begin{array}{l}32 \text { Duration of } \\
\text { breastfeeding in days: } \\
\text { Sensitivity analysis }\end{array}$ & 6 & 264 & $\begin{array}{l}\text { Mean Difference (IV, } \\
\text { Random, 95\% CI) }\end{array}$ & $63.73[37.96,89.50]$ \\
\hline $\begin{array}{l}33 \text { Heart rate } 75 \\
\text { minutes to } 2 \text { hrs post } \\
\text { birth: Sensitivity } \\
\text { analysis }\end{array}$ & 2 & 94 & $\begin{array}{l}\text { Mean Difference (IV, } \\
\text { Fixed, 95\% CI) }\end{array}$ & $-5.77[-7.43,-4.11]$ \\
\hline $\begin{array}{l}34 \text { Respiratory rate } 75 \\
\text { minutes to } 2 \text { hours } \\
\text { post birth: Sensitivity } \\
\text { analysis }\end{array}$ & 3 & 126 & $\begin{array}{l}\text { Mean Difference (IV, } \\
\text { Fixed, 95\% CI) }\end{array}$ & $-4.76[-6.12,-3.41]$ \\
\hline
\end{tabular}

\section{WHAT'S NEW}

Last assessed as up-to-date: 15 March 2012.

\begin{tabular}{lll}
\hline Date & Event & Description \\
\hline 7 March 2012 & $\begin{array}{l}\text { New search has } \\
\text { been performed }\end{array}$ & $\begin{array}{l}\text { The search was updated to 30 November 2011 and, as a result, five } \\
\text { randomized controlled trials have been added to the review. Two of the } \\
\text { new studies (Gouchon 2010; Nolan 2009) were conducted with mothers } \\
\text { scheduled for repeat cesarean birth using regional anesthesia. One study } \\
\text { (Huang 2006) was conducted with hypothermic, but otherwise healthy, } \\
\text { newborns postcesarean birth with spinal anesthesia. The results from four } \\
\text { additional reports involving the data set from Bystrova 2003, two } \\
\text { additional reports from Anderson 2003 and one additional report from } \\
\text { Bergman 2004 have been added to this update. } \\
\text { In this update we have used new methods and have modified outcomes. } \\
\end{array}$ \\
& $\begin{array}{l}\text { One trial previously included has now been excluded because quasi- } \\
\text { randomized trials are no longer included (Anisfeld 1983). }\end{array}$ \\
\hline 30 September 2011 & $\begin{array}{l}\text { New citation } \\
\text { required but } \\
\text { conclusions have } \\
\text { not changed }\end{array}$ & New author helped to update this review. \\
& \\
\hline
\end{tabular}




\section{HISTORY}

Protocol first published: Issue 1, 2002

Review first published: Issue 2, 2003

\begin{tabular}{|c|c|c|}
\hline Date & Event & Description \\
\hline 8 May 2008 & Amended & Converted to new review format. \\
\hline 3 April 2007 & $\begin{array}{l}\text { New search has } \\
\text { been performed }\end{array}$ & $\begin{array}{l}\text { The search was updated to August } 2006 \text {, as a result of which } 17 \text { studies have been } \\
\text { added to the review along with } 23 \text { clinical outcomes. Additional breastfeeding } \\
\text { outcomes include: exclusive breastfeeding up to four to six months postbirth; } \\
\text { starting other feedings before the infant is two months of age; success of the first } \\
\text { breastfeeding; time to effective breastfeeding; number of breastfeeding problems; } \\
\text { frequency of infant mouthing movements with exposure to mother's own milk; and } \\
\text { infant body weight change. New outcomes related to maternal feelings and attitudes } \\
\text { include: preference for the same postdelivery care in the future; perceptions of the } \\
\text { adequacy of her milk supply; self-confidence about her child care ability; and } \\
\text { parenting confidence. Three studies with late preterm infants who were healthy } \\
\text { enough to remain with their mothers on the postpartum unit and between } 34 \text { to } 37 \\
\text { weeks' gestational age have been added to this review. Additional outcomes related } \\
\text { to these infants include: SCRIP scores; number of infants who did not exceed } \\
\text { physiological parameters; transfers to the neonatal intensive care unit; and hospital } \\
\text { length of stay. A new outcome related to infant behavior is optimal flexed } \\
\text { movements. Two outcomes have also been added evaluating maternal attachment: } \\
\text { mean \% of maternal contact time and maternal perceptions of bonding/connection to } \\
\text { her infant. Although } 23 \text { outcomes have been added, there are no significant changes } \\
\text { from the conclusions of the previous review }\end{array}$ \\
\hline 3 April 2007 & $\begin{array}{l}\text { New citation } \\
\text { required but } \\
\text { conclusions } \\
\text { have not } \\
\text { changed }\end{array}$ & This review has been substantially updated. \\
\hline
\end{tabular}

\section{References to studies included in this review}

Anderson 2003. [published data only]* Anderson GC, Chiu SH, Dombrowski MA, Swinth JY, Albert JM, Wada N. Mother-newborn contact in a randomized trial of kangaroo (skin-to-skin) care. Journal of Obstetric, Gynecologic and Neonatal Nursing. 2003; 32(5):604-11.Chiu SH, Anderson GC. Effect of early skin-to-skin contact on mother-preterm infant interaction through 18 months: randomized controlled trial. International Journal of Nursing Studies. 2009; 46(9): 1168-80. [PubMed: 19361802] Hake-Brooks SJ, Anderson GC. Kangaroo care and breastfeeding of mother-preterm infant dyads 0-18 months: a randomized, controlled trial. Neonatal Network. 2003; 27(3):151-9. [PubMed: 18557262]

Bergman 2004. [published data only]Bergman, N. Kangaroo mother care from birth compared to conventional incubator care. 22nd Conference on Priorities in Perinatal Care in South Africa; Free State, South Africa. 2003 March 11-14; 2003. * Bergman NJ, Linley LL, Fawcus SR. Randomized controlled trial of skin-to-skin contact from birth versus conventional incubator for physiological stabilization. Acta Paediatrica. 2004; 93(6):779-85. [PubMed: 15244227] Bigelow A, Littlejohn M, Bergman N, McDonald C. The relation between early mother-infant skin-to-skin contact and later maternal sensitivity in South African mothers of low birth weight infants. Infant Mental Health Journal. 2010; 31(3):358-77.

Bystrova 2003. [published data only]Bystrova K, Ivanova V, Edhborg M, Matthiesen AS, RansjoArvidson AB, Mukhamedrakhimov R, et al. Early contact versus separation: effects on motherinfant interaction one year later. Birth. 2009; 36(2):97-109. [PubMed: 19489802] Bystrova K, Matthiesen AS, Vorontsov I, Widstrom AM, Ransjo-Arvidson AB, Uvnas-Moberg K. Maternal axillar and breast temperature after giving birth: effects of delivery ward practices and relation to infant temperature. Birth. 2007; 34(4):291-300. [PubMed: 18021144] Bystrova K, Matthiesen AS, Widstrom AM, Ransjo-Arvidson AB, Welles-Nystrom B, Vorontsov I, et al. The effect of Russian maternity home routines on breastfeeding and neonatal weight loss with special 
reference to swaddling. Early Human Development. 2007; 83(1):29-39. [PubMed: 16716541] Bystrova K, Widstrom AM, Matthiesen AS, Ransjo-Arvidson AB, Welles-Nystrom B, Vorontsov I, et al. Early lactation performance in primiparous and multiparous women in relation to different maternity home practices. A randomised trial in St. Petersburg. International Breastfeeding Journal. 2007; 2(1):9. [PubMed: 17488524] * Bystrova K, Widstrom AM, Matthiesen AS, Ransjo-Arvidson AB, Welles-Nystrom B, Wassberg C, et al. Skin-to-skin contact may reduce negative consequences of "the stress of being born": a study on temperature in newborn infants, subjected to different ward routines in St. Petersburg. Acta Paediatrica. 2003; 92(3):320-6. [PubMed: 12725547]

Carfoot 2004. [published data only]Carfoot S, Williamson PR, Dickson R. The value of a pilot study in breast-feeding research. Midwifery. 2004; 20(2):188-93. [PubMed: 15177863]

Carfoot 2005. [published data only]Carfoot S, Williamson P, Dickson R. A randomised controlled trial in the north of England examining the effects of skin-to-skin care on breast feeding. Midwifery. 2005; 21(1):71-9. [PubMed: 15740818]

Carlsson 1978. [published data only]Carlsson SG, Fagerberg H, Horneman G, Hwang CP, Larsson K, Rodholm M. Effects of various amounts of contact between mother and child on the mother's nursing behavior: a follow-up study. Infant Behaviour and Development. 1979; 2:209-14.* Carlsson SG, Fagerberg H, Horneman G, Hwang CP, Larsson K, Rodholm M, et al. Effects of amount of contact between mother and child on the mother's nursing behavior. Developmental Psychobiology. 1978; 11:143-50. [PubMed: 640231] Carlsson SG, Larsson K, Schaller J. Early mother-child contact and nursing. Reproduction, Nutrition and Development. 1980; 20:881-9. Hwang CP. Aspects of the mother-infant relationship during nursing 1 and 6 weeks after early and extended postpartum contact. Early Human Development. 1981; 5:279-87. [PubMed: 7261991] Schaller J, Carlsson SG, Larsson K. Effects of extended post-partum mother-child contact on the mother's behavior during nursing. Infant Behavior and Development. 1979; 2:319-24.

Christensson 1992. [published data only]Christensson K, Siles C, Moreno L, Belaustequi A, De La Fuente P, Lagercrantz H, et al. Temperature, metabolic adaptation and crying in healthy full-term newborns cared for skin-to-skin or in a cot. Acta Paediatrica. 1992; 81:488-93. [PubMed: 1392359]

Christensson 1995. [published data only]* Christensson K, Cabrera T, Christensson E, Uvnas Moberg $\mathrm{K}$, Winberg J. Separation distress call in the human neonate in the absence of maternal body contact. Acta Paediatrica. 1995; 84(5):468-73. [PubMed: 7633137] Michelsson K, Christensson K, Rothganger H, Winberg J. Crying in separated and non-separated newborns: sound spectrographic analysis. Acta Paediatrica. 1996; 85:471-5. [PubMed: 8740308]

Chwo 1999. [published data only]* Chwo, MJ. Early kangaroo care for 34-36 week preterm infants: effects on temperature, weight, cortisol, and behavior [dissertation]. Case Western Reserve University; Cleveland (OH): 1999. Chwo MJ, Anderson GC, Good M, Dowling DA, Shiau SH, Chu DM. A randomized controlled trial of early kangaroo care for preterm infants: effects on temperature, weight, behavior, and acuity. Journal of Nursing Research. 2002; 10(2):129-42. [PubMed: 12119598]

Craig 1982. [published data only]Craig S, Tyson JE, Samson J, Lasky RE. The effect of early contact on maternal perception of infant behavior. Early Human Development. 1982; 6:197-204. [PubMed: 7094857]

Curry 1982. [published and unpublished data]* Curry, MA. The effect of skin-to-skin contact between mother and infant during the first hour following delivery on the mother's maternal attachment behavior and self concept [dissertation]. University of California; San Francisco (CA): 1979. Curry MA. Maternal attachment behaviour and the mother's self-concept: the effect of early skin-to-skin contact. Nursing Research. 1982; 31:73-8. [PubMed: 6926651] Curry MAH. Contact during the first hour with the wrapped or naked newborn: effect on maternal attachment behaviors at 36 hours and three months. Birth and the Family Journal. 1979; 6:227-35.

De Chateau 1977. [published data only]De Chateau P. Early post-partum contact and later attitudes. International Journal of Behavioral Development. 1980; 3:273-86.De Chateau P. The first hour after delivery - its impact on synchrony of the parent-infant relationship. Paediatrician. 1980; 9:151-68. [PubMed: 7208067] De Chateau P. The influence of early contact on maternal and infant behaviour in primiparae. Birth and the Family Journal. 1976; 3:149-55.De Chateau P, 
Holmberg H, Jakobsson K, Winberg J. A study of factors promoting and inhibiting lactation. Developmental Medicine and Child Neurology. 1977; 19:575-84. [PubMed: 913896] * De Chateau P, Wiberg B. Long-term effect on mother-infant behaviour of extra contact during the first hour post partum. I. First observations at 36 hours. Acta Paediatrica Scandinavica. 1977; 66:137-43. [PubMed: 842335] De Chateau P, Wiberg P. Long-term effect on mother-infant behaviour of extra contact during the first hour post partum. II. A follow-up at three months. Acta Paediatrica Scandinavica. 1977; 66:145-51. [PubMed: 842336] De Chateau P, Wiberg P. Long-term effect on mother-infant behaviour of extra contact during the first hour post partum. III. Follow-up at one year. Scandinavian Journal of Social Medicine. 1984; 12:91-103. [PubMed: 6463623] Wiberg B, Humble K, De Chateau P. Long-term effect on mother-infant behaviour of extra contact during the first hour post partum. V. Follow-up at three years. Scandinavian Journal of Social Medicine. 1989; 17(2):181-91. [PubMed: 2749204] Winberg, J.; De Chateau, P. Attempts to increase breastfeeding. Proceedings of 5th International Congress on Psychosomatic Medicine in Obstetrics and Gynaecology, "Emotion and Reproduction"; Rome, Italy. 1979. p. 851-4.

Fardig 1980. [published data only]Fardig JA. A comparison of skin-to-skin contact and radiant heaters in promoting neonatal thermoregulation. Journal of Nurse-Midwifery. 1980; 25:19-28. [PubMed: 6898112]

Ferber 2004. [published data only]Ferber SG, Makhoul IR. The effect of skin-to-skin contact (kangaroo care) shortly after birth on the neurobehavioral responses of the term newborn: a randomized, controlled trial. Pediatrics. 2004; 113(4):858-65. [PubMed: 15060238]

Gouchon 2010. [published data only]Gouchon S, Gregori D, Picotto A, Patrucco G, Nangeroni M, Di Giulio P. Skin-to-skin contact after cesarean delivery: an experimental study. Nursing Research. 2010; 59(2):78-84. [PubMed: 20179657]

Hales 1977. [published data only]Hales DJ, Lozoff B, Sosa R, Kennell JH. Defining the limits of the maternal sensitive period. Developmental Medicine and Child Neurology. 1977; 19:454-61. [PubMed: 892242]

Huang 2006. [published data only]Huang YY, Huang CY, Lin SM, Wu SC. Effect of very early kangaroo care on extrauterine temperature adaptation in newborn infants with hypothermia problem. Hu Li Za Zhi. 2006; 53(4):41-8. [PubMed: 16874601]

Kastner 2005. [published data only]* Kastner R, Gingelmaier A, Langer B, Grubert TA, Hartl K, Stauber M. Mother-child relationship before, during and after birth [Die Mutter-Kind-Beziehung pranatal, unter der Geburt und postnatal]. Gynakologische Praxis. 2005; 29(1):109-14.Kastner R, Gingelmaier A, Langer B, Grubert TA, Hartl K, Stauber M. Mother-child relationship before, during and after birth [Die Mutter-Kind-Beziehung pranatal, unter der Geburt und postnatal]. Padiatrische Praxis. 2005-2006; 67(1):13-8.

Khadivzadeh 2008. [published data only]Karimi A, Khadivzadeh T, Tara F. The effect of motherinfant skin to skin contact on mother's attachment. International Journal of Gynecology \& Obstetrics. 2009; 107(Suppl 2):S668.Khadivzadeh T, Karimi A. Randomized controlled trial of very early maternal infant skin-to-skin contact and successful breastfeeding. BJOG: an international journal of obstetrics and gynaecology. 2008; 115(s1):248.* Khadivzadeh T, Karimi A. The effects of post-birth mother-infant skin-to-skin contact on first breastfeeding. International Journal of Nurse Midwifery Research. 2009; 14(3):111-6.

Mazurek 1999. [published data only]Mazurek T, Mikiel-Kostyra K, Mazur J, Wieczorek P, Radwanska B, Pachuta-Wegier L. Influence of immediate newborn care on infant adaptation to the environment [Wplyw postepowania $\mathrm{z}$ noworodkiem bezposrednio po porodzie na cechy jego adaptacji do srodowiska]. Medycyna Wieku Rozwojowego. 1999; 3(2):215-24. [PubMed: 10910653]

McClellan 1980. [published data only]McClellan MS, Cabianca WA. Effects of early mother-infant contact following cesarean birth. Obstetrics \& Gynecology. 1980; 56:52-5. [PubMed: 7383488]

Mizuno 2004. [published data only]Mizuno K, Mizuno N, Shinohara T, Noda M. Mother-infant skinto-skin contact after delivery results in early recognition of own mother's milk odour. Acta Paediatrica. 2004; 93(12):1640-5. [PubMed: 15841774]

Moore 2005. [published data only]* Moore, E. Randomized controlled trial of early mother-infant skin-to-skin contact and breastfeeding success [dissertation]. Vanderbilt University; Nashville 
(TN): 2005. Moore ER, Anderson GC. Randomized controlled trial of very early mother-infant skin-to-skin contact and breastfeeding status. Journal of Midwifery and Women's Health. 2007; Vol. 52(issue 2):116-24.Moore ER, Anderson GC. Randomized controlled trial or early motherinfant skin-to-skin contact and breastfeeding success. Journal of Human Lactation. 2005; 21(4): 488-9.

Nolan 2009. [published data only]Nolan A, Lawrence C. A pilot study of a nursing intervention protocol to minimize maternal-infant separation after Cesarean birth. Journal of Obstetric, Gynecologic, and Neonatal Nursing. 2009; 38(4):430-42.

Punthmatharith 2001. [unpublished data only]Punthmatharith, B. Randomized controlled trial of early kangaroo care (skin-to-skin) care: effects on maternal feelings, maternal-infant interaction and breastfeeding success in Thailand [dissertation]. Case Western Reserve University; Cleveland (OH): 2001.

Shiau 1997. [published and unpublished data]* Shiau, S-HH. Randomized controlled trial of kangaroo care with full-term infants: effects on maternal anxiety, breast-milk maturation, breast engorgement, and breastfeeding status [dissertation]. Case Western Reserve University; Cleveland (OH): 1997. Shiau, S-HH. Randomized controlled trial of kangaroo care with full term infants: effects on breastmilk maturation, breast engorgement, and breastfeeding status. International Breastfeeding Conference, Australia's Breastfeeding Association; Sydney, Australia. 1997 October; 1997.

Sosa 1976a. [published data only]Sosa, R.; Kennell, JH.; Klaus, M.; Urrutia, JJ. The effect of early mother-infant contact on breastfeeding, infection and growth. In: Elliott, K.; Fitzsimons, DW., editors. Breastfeeding and the mother: Ciba Foundation Symposium. Vol. Vol. 45. Elsevier Excerpta Medica; New York: 1976. p. 179-93.

Sosa 1976b. [published data only]Sosa, R.; Kennell, JH.; Klaus, M.; Urrutia, JJ. The effect of early mother-infant contact on breastfeeding, infection and growth. In: Elliott, K.; Fitzsimons, DW., editors. Breastfeeding and the mother: Ciba Foundation Symposium. Vol. Vol. 45. Elsevier Excerpta Medica; New York: 1976. p. 179-93.

Sosa 1976c. [published data only]Sosa, R.; Kennell, JH.; Klaus, M.; Urrutia, JJ. The effect of early mother-infant contact on breastfeeding, infection and growth. In: Elliott, K.; Fitzsimons, DW., editors. Breastfeeding and the mother: Ciba Foundation Symposium. Vol. Vol. 45. Elsevier Excerpta Medica; New York: 1976. p. 179-93.

Svejda 1980. [published data only]Svejda MJ, Campos JJ, Emde RN. Mother-infant bonding: failure to generalize. Child Development. 1980; 51:775-9. [PubMed: 7418513]

Syfrett 1996. [published and unpublished data]* Syfrett, EB. Very early and virtually continuous kangaroo care for 34-36 week gestation preterm infants: effects on temperature, breastfeeding, supplementation and weight [thesis]. University of Florida; Gainesville (FL): 1993. Syfrett, EB.; Anderson, GC. Very early kangaroo care beginning at birth for healthy preterm infants and mothers who choose to breastfeed: effect on outcome. A workshop on the Kangaroo-mother method for low birthweight infants; Trieste, Italy. 1996 October; World Health Organization; 1996.

Thomson 1979. [published data only]Thomson ME, Hartsock TG, Larson C. The importance of immediate postnatal contact: its effect on breastfeeding. Canadian Family Physician. 1979; 25:1374-8. [PubMed: 21297814]

Vaidya 2005. [published data only]Vaidya K, Sharma A, Dhungel S. Effect of early mother-baby close contact over the duration of exclusive breastfeeding. Nepal Medical College Journal: NMCJ. 2005; 7:138-40. [PubMed: 16519083]

Villalon 1993. [published data only]Villalon HU, Alvarez PC. Short term effects of early skin-to-skin contact (kangaroo care) on breastfeeding in healthy full-term newborns [Efecto a corto plazo del contacto precoz piel a piel sobre la lactancia materna en recien nacidos de termino sanos]. Revista Chilena de Pediatria. 1993; 64(2):124-8** Villalon HU, Alvarez PC, Barria EH, Caneleo DH, Carrillo LM, Duran SG. Effect of early skin-to-skin contact on temperature regulation, heart rate, and respiratory rate in healthy, full-term newborns [Contacto precoz piel a piel: efecto sobre los parametros fisiologicos en las cuatro horas posteriores al parto en recien nacidos de termino sanos]. Revista Chilena de Pediatria. 1992; 63(3):140-4. 


\section{References to studies excluded from this review}

Abdel Razek 2009. [published data only]Abdel Razek A, Az El-Dein N. Effect of breast-feeding on pain relief during infant immunization injections. International Journal of Nursing Practice. 2009; 15(2):99-104. [PubMed: 19335527]

Ali 1981. [published data only]Ali Z, Lowry M. Early maternal-child contact: effects on later behavior. Developmental Medicine and Child Neurology. 1981; 23:337-45. [PubMed: 7250542]

Anisfeld 1983. [published data only]Anisfeld E, Lipper E. Early contact, social support, and motherinfant bonding. Pediatrics. 1983; 72:79-83. [PubMed: 6683399]

Castral 2008. [published data only]Castral TC, Warnock F, Leite AM, Haas VJ, Scochi CG. The effects of skin-to-skin contact during acute pain in preterm newborns. European Journal of Pain. 2008; 12(4):464-71. [PubMed: 17869557]

Cattaneo 1998. [published data only]Cattaneo A, Davanzo R, Worku B, Surjono A, Echeverria M, Bedri A, et al. Kangaroo mother care for low birthweight infants: a randomized controlled trial in different settings. Acta Paediatrica. 1998; 87(9):976-85. [PubMed: 9764894]

Christensson 1998. [published data only]Christensson K, Bhat GJ, Amadi BC. Randomised study of skin-to-skin versus incubator care for rewarming low-risk hypothermic neonates. Lancet. 1998; 352:1115. [PubMed: 9798589]

Darmstadt 2006. [published data only]Darmstadt GL, Kumar V, Yadav R, Singh V, Singh P, Mohanty $\mathrm{S}$, et al. Introduction of community-based skin-to-skin care in rural Uttar Pradesh, India. Journal of Perinatology. 2006; 26(10):597-604. [PubMed: 16915302]

Durand 1997. [published data only]Durand R, Hodges S, LaRock S, Lund L, Schmid S, Swick D, et al. The effect of skin-to-skin breastfeeding in the immediate recovery period on newborn thermoregulation and blood glucose values. Neonatal Intensive Care. 1997; 3/4:23-9.

Erlandsson 2007. [published data only]Erlandsson K, Dsilna A, Fagerberg I, Christensson K. Skin-toskin care with the father after cesarean birth and its effect on newborn crying and prefeeding behavior. Birth. 2007; 34(2):105-14. [PubMed: 17542814]

Feldman 2003. [published data only]Feldman R, Weller A, Sirota L, Eidelman AI. Testing a family intervention hypothesis: the contribution of mother-infant skin-to-skin contact (kangaroo care) to family interaction, proximity, and touch. Journal of Family Psychology. 2003; 17(1):94-107. [PubMed: 12666466]

Ferber 2008. [published data only]Ferber SG, Makhoul IR. Neurobehavioural assessment of skin-toskin effects on reaction to pain in preterm infants: a randomized, controlled within-subject trial. Acta Paediatrica. 2008; 97(2):171-6. [PubMed: 18177441]

Gardner 1979. [published data only]Gardner S. The mother as incubator-after delivery. Journal of Obstetric, Gynecologic and Neonatal Nursing. 1979; 8(3):174-6.

Gathwala 2008. [published data only]* Gathwala G, Singh B, Balhara B. KMC facilitates mother baby attachment in low birth weight infants. Indian Journal of Pediatrics. 2008; 75(1):43-7. [PubMed: 18245934] Gathwala G, Singh B, Singh J. Effect of Kangaroo Mother Care on physical growth, breastfeeding and its acceptability. Tropical Doctor. 2010; 40(4):199-202. [PubMed: 20667921]

Gomes-Pedro 1984. [published data only]Gomes-Pedro J, Bento de Almeida J, Silveira da Costa C, Barbosa A. Influence of early mother-infant contact on dyadic behaviour during the first month of life. Developmental Medicine and Child Neurology. 1984; 26:657-64. [PubMed: 6510565]

Gray 2000. [published data only]Gray L, Watt L, Blass EM. Skin-to-skin contact is analgesic in healthy newborns. Pediatrics. 2000; 105(1):e14. [PubMed: 10617751]

Gray 2002. [published data only]Gray L, Miller LW, Philipp BL, Blass EM. Breastfeeding is analgesic in healthy newborns. Pediatrics. 2002; 109:590-3. [PubMed: 11927701]

Grossman 1981. [published data only]Grossman K, Thane K, Grossman KE. Maternal tactual contact of the newborn after various postpartum conditions of mother-infant contact. Developmental Psychobiology. 1981; 17:158-69.

Hill 1979. [published data only]Hill ST, Shronk LK. The effect of early parent-infant contact on newborn body temperature. Journal of Obstetric, Gynecologic and Neonatal Nursing. 1979; 8(5): 287-90. 
Ibe 2004. [published data only]Ibe OE, Austin T, Sullivan K, Fabanwo O, Disu E, Costello AM. A comparison of kangaroo mother care and conventional incubator care for thermal regulation of infants $<2000 \mathrm{~g}$ in Nigeria using continuous ambulatory temperature monitoring. Annals of Tropical Pediatrics. 2004; 24:245-51.

Johanson 1992. [published data only]Johanson RB, Malla DS, Rolfe P, Spencer A. The effect of postdelivery care on neonatal body temperature. Early Human Development. 1990; 21:132-3.* Johanson RB, Spencer SA, Rolfe P, Jones P, Malla DS. Effect of post-delivery care on neonatal body temperature. Acta Paediatrica. 1992; 81:859-63. [PubMed: 1467605]

Johnson 1976. [published data only]Johnson NW. Breast-feeding at one hour of age. American Journal of Maternal-Child Nursing. 1976; 1:12-6. [PubMed: 815736]

Kadam 2005. [published data only]Kadam S, Binoy S, Kanbur W, Mondkar JA, Fernandez A. Feasibility of kangaroo mother care in Mumbai. Indian Journal of Pediatrics. 2005; 72(1):35-8. [PubMed: 15684446]

Karlsson 1996. [published data only]Karlsson H. Skin to skin care: heat balance. Archives of Disease in Childhood. 1996; 75:F130-F132. [PubMed: 8949698]

Klaus 1972. [published data only]Kennell JH, Jerauld R, Wolfe H, Chesler D, Kreger NC, McAlpine W. Maternal behavior one year after early and extended post-partum contact. Developmental Medicine and Child Neurology. 1974; 16:172-9. [PubMed: 4836546] Kennell, JH.; Trause, MA.; Klaus, MH. Parent infant interaction. Vol. Vol. 33. CIBA Foundation Symposium; 1975. Evidence for a sensitive period in the human mother; p. 87-101.* Klaus M, Jerauld R, Kreger N, McAlpine W, Steffa M, Kennell J. Maternal attachment: importance of the first postpartum days. New England Journal of Medicine. 1972; 286:460-3. [PubMed: 5009748] Ringler N, Kennell JH, Klaus MH, Navojosky B. Mother to child speech at two years: the effects of increased postnatal contact. Pediatric Research. 1974; 8:345.Ringler N, Trause MA, Klaus MH, Kennell JH. The effects of extra postpartum contact and maternal speech patterns on children's IQs, speech and language comprehension at five. Child Development. 1978; 49:862-5.Ringler NM, Kennell JH, Jarvella R, Navojosky BJ, Klaus MH. Mother-to-child speech at 2 years: effect of early postnatal contact. Journal of Pediatrics. 1975; 86:141-4. [PubMed: 1110438]

Kontos 1978. [published data only]Kontos D. A study of the effects of extended mother-infant contact on maternal behavior at one and three months. Birth and the Family Journal. 1978; 5(3):133-40.

Lindenberg 1990. [published data only]Lindenberg CS, Artola RC, Jimenez V. The effect of early postpartum mother-infant contact and breastfeeding promotion on the incidence and continuation of breastfeeding. International Journal of Nursing Studies. 1990; 27:179-86. [PubMed: 2379980]

Ludington-Hoe 2004. [published data only]Ludington-Hoe SM, Anderson GC, Swinth JY, Thompson C, Hadeed AJ. Randomized controlled trial of kangaroo care: cardiorespiratory and thermal effects on healthy preterm infants. Neonatal Network - Journal of Neonatal Nursing. 2004; 23(3): 39-48.

Ludington-Hoe 2006. [published data only]Ludington-Hoe SM, Johnson MW, Morgan K, Lewis T, Gutman J, Wilson PD, et al. Neurophysiologic assessment of neonatal sleep organization: preliminary results of a randomized, controlled trial of skin contact with preterm infants. Pediatrics. 2006; 117(5):e909-23. [PubMed: 16651294]

Marin 2010. [published data only]Marin Gabriel MA, Llana Martin I, Lopez Escobar A, Fernandez Villalba E, Romero Blanco I, Touza Pol P. Randomized controlled trial of early skin-to-skin contact: effects on the mother and the newborn. Acta Paediatrica. 2010; Vol. 99(issue 11):16304. [PubMed: 19912138]

Mikiel-Kostyra 2002. [published data only]Mikiel-Kostyra K, Boltruszko I, Mazur J. Skin-to-skin contact after birth as a factor determining breastfeeding duration [Kontakt skora-do-skory po porodzie jako czynnik warunkujacy czas trwania karmienia piersia]. Medycyna Wieku Rozwojowego. 2001; 5(2):179-89. [PubMed: 11679683] * Mikiel-Kostyra K, Mazur J, Boltruszko I. Effect of early skin-to-skin contact after delivery on duration of breastfeeding: a prospective cohort study. Acta Paediatrica. 2002; 91(12):1301-6. [PubMed: 12578285]

Miles 2006. [published data only]Miles R, Cowan F, Glover V, Stevenson J, Modi N. A controlled trial of skin-to-skin contact in extremely preterm infants. Early Human Development. 2006; 82(7):447-55. [PubMed: 16458458] 
Nagai 2010. [published data only]S, Nagai; Andrianarimanana, D.; Rabesandratana, N.; Yonemoto, N.; Nakayama, T.; Mori, R. Earlier versus later continuous Kangaroo Mother Care (KMC) for stable low-birth-weight infants: a randomized controlled trial. Acta Paediatrica. 2010; 99(6):82735. [PubMed: 20121708]

Neu 2010. [published data only]Neu M, Robinson J. Maternal holding of preterm infants during the early weeks after birth and dyad interaction at six months. JOGNN - Journal of Obstetric, Gynecologic \& Neonatal Nursing. 2010; 39(4):401-14.

Ohgi 2002. [published data only] Ohgi S, Fukuda M, Moriuchi H, Kusumoto T, Akiyama T, Nugent JK, et al. Comparison of kangaroo care and standard care: behavioral organization, development, and temperament in healthy, low-birth-weight infants through 1 year. Journal of Perinatology. 2002; 22(5):374-9. [PubMed: 12082472]

Okan 2010. [published data only]Okan F, Ozdil A, Bulbul A, Yapici Z, Nuhoglu A. Analgesic effects of skin-to-skin contact and breastfeeding in procedural pain in healthy term neonates. Annals of Tropical Paediatrics. 2010; 30(2):119-28. [PubMed: 20522298]

Ottaviano 1979. [published data only]Ottaviano CM, Campbell SBG, Taylor PM. The effects of extra postpartum contact on infant-mother attachment at one year. Pediatric Research. 1979; 13:336.

Ramanathan 2001. [published data only]Ramanathan K, Paul VK, Deorari AK, Taneja U, George G. Kangaroo mother care in very low birth weight infants. Indian Journal of Pediatrics. 2001; 68(11):1019-23. [PubMed: 11770234]

Roberts 2000. [published data only]Roberts KL, Paynter C, McEwan B. A comparison of kangaroo mother care and conventional cuddling care. Neonatal Network - Journal of Neonatal Nursing. 2000; 19(4):31-5.

Rojas 2001. [published data only]Rojas MA, Kaplan M, Mayes L, Quevedo ME, Foster LB, Sherwonit E, et al. Traditional holding (TH) and skin-to-skin care (SSC) for newborn infants $<=1500$ grams. A randomized controlled trial [abstract]. Pediatric Research. 2001; 49(4):360A.

Salariya 1978. [published data only]Salariya EM, Easton PM, Cater JI. Duration of breastfeeding after early initiation and frequent feeding. Lancet. 1978; 2:1141-3. [PubMed: 82695]

Sloan 2008. [published data only]Ahmed S, Mitra SN, Chowdhury AM, Camacho LL, Winikoff B, Sloan NL. Community Kangaroo Mother Care: implementation and potential for neonatal survival and health in very low-income settings. Journal of Perinatology. 2011; 31(5):361-7. [PubMed: 21311502] Sloan, NL.; Ahmed, S.; Chowdhury, N.; Mitra, S.; Chowdhury, M.; Rob, U. Community-based kangaroo mother care to prevent neonatal mortality [abstract]. Pediatric Academic Societies Annual Meeting; San Francisco, CA, USA. 2006 April 29-May 2; 2006. * Sloan NL, Ahmed S, Mitra SN, Choudhury N, Chowdhury M, Rob U, et al. Community-based kangaroo mother care to prevent neonatal and infant mortality: a randomized, controlled cluster trial. Pediatrics. 2008; 121(5):e1047-59. [PubMed: 18450847]

Suman 2008. [published data only]Suman Rao PN, Udani R, Nanavati R. Kangaroo mother care for low birth weight infants: a randomized controlled trial. Indian Pediatrics. 2008; 45(1):17-23. [PubMed: 18250500]

Taylor 1979. [published data only]Taylor PM, Campbell SBG, Taylor FH, Maloni J, Dickey D, Rubenstein G. Short-term effects of extra mother-first born contact. Pediatric Research. 1979; $13: 338$.

Taylor 1985. [published data only]Taylor PM, Maloni JA, Taylor FH, Campbell SB. Extra early mother-infant contact and duration of breastfeeding. Acta Paediatrica Scandinavica Supplement. 1985; 316:15-22. [PubMed: 3861069] * Taylor PM, Taylor FH, Campbell SB, Maloni JA, Cannon M. Extra early physical contact and aspects of the early mother-infant relationship. Acta Paediatrica Scandinavica Supplement. 1985; 316:3-14. [PubMed: 3861070]

Taylor 1986. [published data only]Taylor PM, Maloni JA, Brown DR. Early sucking and prolonged breastfeeding. American Journal of Diseases of Children. 1986; 140:151-4. [PubMed: 3946324]

Tessier 2009. [published data only]Tessier R, Charpak N, Giron M, Cristo M, de Calume ZF, RuizPelaez JG. Kangaroo Mother Care, home environment and father involvement in the first year of life: a randomized controlled study. Acta Paediatrica. 2009; 98(9):1444-50. [PubMed: 19500083]

Thukral 2010. [published data only]Thukral, A.; Sankar, J.; Agarwal, R.; Deorari, A.; Paul, V. Effect of early skin to skin (STS) contact on breastfeeding behavior in term neonates: a randomized 
trial. Pediatric Academic Societies 2010 Annual Meeting; Vancouver, Canada. 2010 May 1-4; 2010.

Velandia 2010. [published data only]Velandia M, Matthisen AS, Uvnas-Moberg K, Nissen E. Onset of vocal interaction between parents and newborns in skin-to-skin contact immediately after elective caesarean section. Birth. 2010; 37(3):192-201. [PubMed: 20887535]

Wimmer 1982. [published data only]Wimmer-Puchinger, B.; Nagel, M. The importance of attitudes during pregnancy and early mother-child contact for breastfeeding behavior: an empirical study. In: Prill, HJ.; Stauber, M., editors. Advances in Psychosomatic Obstetrics and Gynecology. Springer-Verlag: 1982. p. 482-4.

Worku 2005. [published data only]Worku B, Kassie A. Kangaroo mother care: a randomized controlled trial on effectiveness of early kangaroo mother care for the low birthweight infants in Addis Ababa, Ethiopia. Journal of Tropical Pediatrics. 2005; 51(2):93-7. [PubMed: 15840760]

\section{References to ongoing studies}

Keshavarz 2010. [published data only]Keshavarz, M. [accessed 6 December 2010] Comparison the effect of skin to skin contact and music during skin to skin contact on maternal state anxiety in cesarean section unit. IRCT Iranian Registry of Clinical Trials. 2010. www.irct.irwww.irct.ir

\section{Additional references}

Affonso 1989. [published data only]Affonso D, Wahlberg V, Persson B. Exploration of mother's reactions to the kangaroo method of prematurity care. Neonatal Network. 1989; 7(6):43-51. [PubMed: 2733681]

Alberts 1994. Alberts JR. Learning as adaptation of the infant. Acta Paediatrica Supplement. 1994; 397:77-85.

American Academy of Pediatrics 2005. Gartner LM, Morton J, Lawrence RA, Naylor AJ, O'Hare D, Schanler RJ, et al. Breastfeeding and the use of human milk. Pediatrics. 2005; 115(2):496-506. [PubMed: 15687461]

Anderson 1989. Anderson GC. Risk in mother-infant separation postbirth. Image. 1989; 21:196-9.

Anderson 1995. Anderson GC, Chang H-P, Behnke M, Conlon M, Eyler FD. Self- regulatory mothering (SR) postbirth: effect on, and correlation between, infant crying and salivary cortisol. Pediatric Research. 1995; 37(4 Pt 2):12A.

Anderson 2004a. Anderson, GC.; Chiu, SH.; Morrison, B.; Burkhammer, M.; Ludington-Hoe, S. Skinto-skin care for breastfeeding difficulties postbirth. In: Field, T., editor. Touch and Massage Therapy in Early Development. Johnson \& Johnson Pediatric Institute; New Brunswick: 2004. p. 115-36.

Anderson 2004b. Anderson GC, Radjenovic D, Chiu SH, Conlon M, Lane AE. Development of an observational instrument to measure mother-infant separation post birth. Journal of Nursing Measurement. 2004; 12(3):215-34. [PubMed: 16138726]

Bernard-Bonnin 1989. Bernard-Bonnin AC, Stachtchenko S, Girard G, Rousseau E. Hospital practices and breast-feeding duration: a meta-analysis of controlled trials. Birth. 1989; 16:64-6. [PubMed: 2547392]

Bramson 2010. Bramson L, Lee JW, Moore E, Montgomery S, Neish C, Bahjri K. Effect of early skinto-skin mother-infant contact during the first 3 hours following birth on exclusive breastfeeding during the maternity hospital stay. Journal of Human Lactation. 2010; 26(2):130-7. [PubMed: 20110561]

Bystrova 2007a. Bystrova K, Matthiesen AS, Widstrom AM, Ransjo-Arvidson AB, Welles-Nystrom $\mathrm{B}$, Vorontsov I, et al. The effect of Russian maternity home routines on breastfeeding and neonatal weight loss with special reference to swaddling. Early Human Development. 2007; 83(1):29-39. [PubMed: 16716541]

Bystrova 2007b. Bystrova K, Widstrom AM, Matthiesen AS, Ransjo-Arvidson AB, Welles-Nystrom $\mathrm{B}$, Vorontsov I, et al. Early lactation performance in primiparous and multiparous women in relation to different maternity home practices. A randomised trial in St. Petersburg. International Breastfeeding Journal. 2007; 2(1):9. [PubMed: 17488524] 
Bystrova 2007c. Bystrova K, Matthiesen AS, Vorontsov I, Widstrom AM, Ransjo-Arvidson AB, Uvnas-Moberg K. Maternal axillar and breast temperature after giving birth: effects of delivery ward practices and relation to infant temperature. Birth. 2007; 34(4):291-300. [PubMed: 18021144]

Bystrova 2009. Bystrova K, Ivanova V, Edhborg M, Matthiesen AS, Ransjo-Arvidson AB, Mukhamedrakhimov R, et al. Early contact versus separation: effects on mother-infant interaction one year later. Birth. 2009; 36(2):97-109. [PubMed: 19489802]

Chiu 2005. Chiu SH, Anderson GC, Burkhammer MD. Newborn temperature during skin-to-skin breastfeeding in couples having breastfeeding difficulties. Birth. 2005; 32(2):115-21. [PubMed: 15918868]

Chiu 2008. Chiu SH, Anderson GC, Burkhammer MD. Can skin-to-skin contact help reduce racial disparities in postpartum women having breastfeeding difficulties? Breastfeeding Medicine. 2008; 3(4):231-7. [PubMed: 19086826]

Chiu 2009. Chiu SH, Anderson GC. Effect of early skin-to-skin contact on mother-preterm infant interaction through 18 months: randomized controlled trial. International Journal of Nursing Studies. 2009; 46(9):1168-80. [PubMed: 19361802]

Christidis 2003. Christidis I, Zotter H, Rosegger H, Engele H, Kurz R, Kerbl R. Infrared thermography in newborns: the first hour after birth. Gynakologisch Geburtschilfliche Rundschau. 2003; Vol. 43:31-5.

Clark 1985. Clark, R. The parent-child early relational assessment: instrument and manual. Department of Psychiatry, University of Wisconsin Medical School; Madison, Wisconsin: 1985.

Clark 1999. Clark R. The parent-child early relational assessment: a factorial validity study. Educational and Psychological Measurement. 1999; 59(5):821-46.

Conde-Agudelo 2011. Conde-Agudelo A, Diaz-Rossello JL, Belizam JM. Kangaroo mother care to reduce morbidity and mortality in low birthweight infants. Cochrane Database of Systematic Reviews. 2011; (Issue 3) DOI: 10.1002/14651858.CD002771.

Dageville 2008. Dageville C, Pignol J, De Smet S. Very early neonatal apparent life-threatening events and sudden unexpected deaths: incidence and risk factors. Acta Paediatrica. 2008; Vol. 97:866-9. [PubMed: 18482167]

De Carvalho 1983. De Carvalho M, Robertson S, Friedman A, Klaus M. Effect of frequent breastfeeding on early milk production and infant weight gain. Pediatrics. 1983; 72:307-11. [PubMed: 6889034]

Del Sette 1998. Del Sette M, Angeli S, Leandri M, Ferriero G, Bruzzone GL, Finocchi C. Migraine with aura and right-to-left shunt on transcranial Doppler: a case-control study. Cerebrovascular Diseases. 1998; 8(6):327-30. [PubMed: 9774749]

Dennis 1999. Dennis C. Theoretical underpinnings of breast-feeding confidence: a self-efficacy framework. Journal of Human Lactation. 1999; 15:195-201. [PubMed: 10578797]

Dewey 2003. Dewey KG, Nommsen-Rivers LA, Heinig MJ, Cohen RJ. Risk factors for suboptimal infant breastfeeding behavior, delayed onset of lactation, and excess neonatal weight loss. Pediatrics. 2003; 112(3 Pt 1):607-19. [PubMed: 12949292]

Dordevic 2008. Dordevic G, Jovanovic B, Dordevic M. An early contact with the baby - benefit for the mother. Medicina Preglio. 2008; 61(11-12):576-9.

Egger 1997. Egger M, Davey Smith G, Schneider M, Minder C. Bias in meta-analysis detected by a simple, graphical test. BMJ. 1997; 315(7109):629-34. [PubMed: 9310563]

Fischer 1998. Fischer CB, Sontheimer D, Scheffer F, Bauer J, Linderkamp O. Cardiorespiratory stability of premature boys and girls during kangaroo care. Early Human Development. 1998; 52(2):145-53. [PubMed: 9783816]

Francis 1999. Francis D, Diorio J, Liu D, Meaney MJ. Nongenomic transmission across generations of maternal behavior and stress responses in the rat. Science. 1999; 286:1155-8. [PubMed: 10550053]

Gomez 1998. Gomez P, Baiges Nogues MT, Batiste Fernandez MT, Marca Gutierrez MM, Nieto Jurado A, Closa Monasterolo R. Kangaroo method in delivery room for full-term babies [Metodo canguro en sala de partos en recien nacidos a termino]. Anales Espanoles De Pediatria. 1998; 48(6):631-3. [PubMed: 9662849] 
Grummer-Strawn 2008. Grummer-Strawn LM, Scanlon KS, Fein SB. Infant feeding and feeding transitions during the first year of life. Pediatrics. 2008; Vol. 122:S36-S42. [PubMed: 18829829]

Hake-Brooks 2003. Hake-Brooks SJ, Anderson GC. Kangaroo care and breastfeeding of motherpreterm infant dyads 0-18 months: a randomized, controlled trial. Neonatal Network. 2003; 27(3):151-9. [PubMed: 18557262]

Handlin 2009. Handlin L, Jonas W, Petersson M, Ejdeback M, Ransjo-Arvidson AB, Nissen E, et al. Effects of sucking and skin-to-skin contact on maternal ACTH and cortisol levels during the second day postpartum-influence of epidural analgesia and oxytocin in the perinatal period. Breastfeeding Medicine. 2009; Vol. 4(issue 4):207-20. [PubMed: 19731998]

Harbord 2006. Harbord RM, Egger M, Sterne JA. A modified test for small-study effects in metaanalyses of controlled trials with binary endpoints. Statistics in Medicine. 2006; 25(20):3443-57. [PubMed: 16345038]

Higgins 2011. Higgins, JPT.; Green, S., editors. Cochrane Handbook for Systematic Reviews of Interventions. Version 5.1.0. The Cochrane Collaboration; 2011. www.cochranehandbook.org[updated March 2011]

Hill 1994. Hill P, Humenick SS. The occurrence of breast engorgement. Journal of Human Lactation. 1994; 10:79-86. [PubMed: 7619260]

Hill 1996. Hill PD, Humenick SS. Development of the H\&H Lactation Scale. Nursing Research. 1996; 45:136-40. [PubMed: 8637793]

Hill 2007. Hill PD, Johnson TS. Assessment of breastfeeding and infant growth. Journal of Midwifery and Womens Health. 2007; 52(6):571-8.

Inch 1989. Inch, S.; Garforth, S. Establishing and maintaining breast-feeding. In: Chalmers, I.; Enkin, M.; Keirse, M., editors. Effective Care in Pregnancy and Childbirth. Oxford University Press; Oxford: 1989. p. 1359-74.

Jansson 1995. Jansson UM, Mustafa T, Khan MA, Lindblad BS, Widstrom AM. The effects of medically-oriented labour ward routines on prefeeding behaviour and body temperature in newborn infants. Journal of Tropical Pediatrics. 1995; 41:360-3. [PubMed: 8606445]

Labbok 1990. Labbok M, Krasovec K. Toward consistency in breastfeeding definitions. Studies in Family Planning. 1990; 21:226-30. [PubMed: 2219227]

Lagercrantz 1986. Lagercrantz H, Slotkin TA. The "stress" of being born. Scientific American. 1986; 254(4):100-7. [PubMed: 3961465]

Lagercrantz 1996. Lagercrantz H. Stress, arousal and gene activation at birth. News in Physiological Science. 1996; 11:214-8.

Liu 1997. Liu D, Diorio JC, Tannenbaum B, Caldji C, Francis D, Freedman A, et al. Maternal care, hippocampal glucocorticoid receptor expression and hypothalamic-pituitary-adrenal responses to stress. Science. 1997; 277:1659-62. [PubMed: 9287218]

Liu 2000. Liu D, Diorio J, Day JC, Francis DD, Meaney MJ. Maternal care, hippocampal synaptogenesis and cognitive development in rats. Nature Neuroscience. 2000; 3:799-806.

Lucas 2005. Lucas A. Long-term programming effects of early nutrition -- implications for the preterm infant. Journal of Perinatology. 2005; 25(Suppl 2):S2-S6. [PubMed: 15861165]

Ludington-Hoe 2002. Ludington-Hoe SM, Cong X, Hashemi F. Infant crying: nature, physiologic consequences, and select interventions. Neonatal Network. 2002; Vol. 21(issue 2):29-36. [PubMed: 11923998]

Matthews 1988. Matthews MK. Developing an instrument to assess infant breastfeeding behaviour in the early neonatal period. Midwifery. 1988; 4(4):154-65. [PubMed: 3210979]

Matthews 1991. Matthews MK. Mothers' satisfaction with their neonates' breastfeeding behaviors. Journal of Obstetric, Gynecologic and Neonatal Nursing. 1991; 20(1):49-55.

McEwen 1998. McEwen BS. Stress, adaptation, and disease. Allostasis and allostatic load. Annals of the New York Academy of Science. 1998; 840:33-44.

Meaney 2005. Meaney MJ, Szyf M. Maternal care as a model for experience-dependent chromatin plasticity? Trends in Neurosciences. 2005; 28(9):456-63. [PubMed: 16054244]

Michelsson 1996. Michelsson K, Christensson K, Rothganger H, Winberg J. Crying in separated and non-separated newborns: sound spectrographic analysis. Acta Paediatrica. 1996; 85:471-5. [PubMed: 8740308] 
Moher 2001. Moher D, Schultz KF, Altman DA. The Consort statement: Revised recommendations for improving the quality of reports of parallel group randomized trials. JAMA. 2001; 285:198791. [PubMed: 11308435]

Moher 2010. Moher D, Hopewell S, Schultz K, Montori V, Gotzsche P, Devereaux PJ, et al. CONSORT 2010 explanation and elaboration: updated guidelines for reporting parallel group randomised trials. BMJ. 2010; 340:c869. [PubMed: 20332511]

Mori 2010. Mori R, Khanna R, Pledge D, Nakayama T. Meta-analysis of physiological effects of skinto-skin contact for newborns and mothers. Pediatrics International. 2010; Vol. 52:161-70. [PubMed: 19519670]

O’Campo 1992. O’Campo P, Faden R, Gielen A, Wang M. Prenatal factors associated with breastfeeding duration: recommendations for prenatal interventions. Birth. 1992; 19:195-201. [PubMed: 1472267]

Odent 2001. Odent M. New reasons and new ways to study birth physiology. International Journal of Gynecology \& Obstetrics. 2001; 75(Suppl 1):S39-S45. [PubMed: 11742641]

Perez-Escamilla 1994. Perez-Escamilla R, Pollitt E, Lonnerdal B, Dewey KG. Infant feeding policies in maternity wards and their effect on breast-feeding success: an analytic overview. American Journal of Public Health. 1994; 84:89-97. [PubMed: 8279619]

Plotsky 2005. Plotsky PM, Thrivikraman KV, Nemeroff CB, Caldji C, Sharma S, Meaney MJ. Longterm consequences of neonatal rearing on central corticotropin-releasing factor systems in adult male rat offspring. Neuropsychopharmacology. 2005; 30:2192-204. [PubMed: 15920504]

Poletto 2006. Poletto R, Steibel JP, Siegford JM, Zanella AJ. Effects of early weaning and social isolation on the expression of glucocorticoid and mineralocorticoid receptor and 11 betahydroxysteroid dehydrogenase 1 and 2 mRNAs in the frontal cortex and hippocampus of piglets. Brain Research. 2006; Vol. 1067(issue 1):36-42. [PubMed: 16271354]

Polit 2011. Polit DF, Gillespie BM, Griffin R. Deliberate ignorance: a systematic review of blinding in nursing clinical trials. Nursing Research. 2011; 60(1):9-16. [PubMed: 21127453]

Porges 2007. Porges SW. The polyvagal perspective. Biological Psychology. 2007; 74(2):116-43. [PubMed: 17049418]

Porter 1999. Porter RH, Winberg J. Unique salience of maternal breast odors for newborn infants. Neuroscience and Biobehavioral Reviews. 1999; 23:439-49. [PubMed: 9989430]

Raju 2006. Raju TN, Higgins RD, Stark AR, Leveno KJ. Optimizing care and outcome for latepreterm (near-term) infants: a summary of the workshop sponsored by the National Institute of Child Health and Human Development. Pediatrics. 2006; Vol. 118:1207-14. [PubMed: 16951017]

RevMan 2011. The Nordic Cochrane Centre. The Cochrane Collaboration. Review Manager (RevMan). 5.1. The Nordic Cochrane Centre, The Cochrane Collaboration; Copenhagen: 2011.

Righard 1990. Righard L, Alade MO. Effect of delivery room routines on success of first breast-feed. Lancet. 1990; 336:1105-7. [PubMed: 1977988]

Riordan 1997. Riordan JM. Reliability and validity testing of three breastfeeding assessment tools. Journal of Obstetric, Gynecologic and Neonatal Nursing. 1997; 26:181-7.

Rogers 1997. Rogers IS, Emmett PM, Golding J. The incidence and duration of breast-feeding. Early Human Development. 1997; 49:S45-S74. [PubMed: 9363417]

Shannon 2007. Shannon M, King TL, Kennedy HP. Allostasis: a theoretical framework for understanding and evaluating perinatal health outcomes. Journal of Obstetric, Gynecologic and Neonatal Nursing. 2007; 36(2):125-34.

Thomson 1984. Thomson ME, Kramer MS. Methodological standards for controlled clinical trials of early contact and maternal-infant behavior. Pediatrics. 1984; 73:294-300. [PubMed: 6701052]

Thulier 2010. Thulier D. A call for clarity in infant breast and bottle-feeding definitions for research. Journal of Obstetric, Gynecologic and Neonatal Nursing. 2010; 39:627-634.

Uvnas-Moberg 1996. Uvnas-Moberg K, Eriksson M. Breastfeeding: physiological, endocrine and behavioural adaptations caused by oxytocin and local neurogenic activity in the nipple and mammary gland. Acta Paediatrica. 1996; Vol. 85:525-30. [PubMed: 8827091]

Uvnas-Moberg 1998. Uvnas-Moberg K. Oxytocin may mediate the benefits of positive social interactions and emotions. Psychoneuroendocrinology. 1998; 23:819-35. [PubMed: 9924739] 
Uvnas-Moberg 2005. Uvnas-Moberg K, Arn I, Magnusson D. The psychobiology of emotion: the role of the oxytocinergic system. International Journal of Behavioral Medicine. 2005; Vol. 12(issue 2):59-65.

Varendi 1994. Varendi H, Porter RH, Winberg J. Does the newborn baby find the nipple by smell? Lancet. 1994; 344:989-90. [PubMed: 7934434]

Varendi 1997. Varendi H, Porter RH, Winberg J. Natural odor preferences of newborn infants change over time. Acta Paediatrica. 1997; 86:985-90. [PubMed: 9343280]

Varendi 1998. Varendi H, Christensson K, Porter RH, Winberg J. Soothing effect of amniotic fluid smell in newborn infants. Early Human Development. 1998; 51:47-55. [PubMed: 9570031]

Widstrom 1987. Widstrom AM, Ransjo-Arvidson AB, Christensson K, Matthiesen AS, Winberg J, Uvnas-Moberg K. Gastric suction in healthy newborn infants: effects on circulation and developing feeding behavior. Acta Paediatrica Scandinavica. 1987; 76:566-72. [PubMed: 3630673]

Widstrom 1990. Widstrom AM, Wahlberg V, Matthiesen AS, Eneroth P, Uvnas-Moberg K, Werner S, et al. Short-term effects of early suckling and touch of the nipple on maternal behavior. Early Human Development. 1990; 21:153-63. [PubMed: 2311552]

Widstrom 2011. Widstrom AM, Lilja G, Aaltomaa-Michalias P, Dahllof A, Lintula M, Nissen E. Newborn behaviour to locate the breast when skin-to-skin: a possible method for enabling early self-regulation. Acta Paediatrica. 2011; Vol. 100:79-85. [PubMed: 20712833]

Winberg 1995. Winberg J. Examining breast-feeding performance: forgotten influencing factors. Acta Paediatrica. 1995; 84:465-7. [PubMed: 7633136]

Winberg 2005. Winberg J. Mother and newborn baby: mutual regulation of physiology and behavior-a selective review. Developmental Psychobiology. 2005; 47(3):217-29. [PubMed: 16252290]

Ziabreva 2003. Ziabreva I, Poeggel G, Schnabel R, Braun K. Separation-induced receptor changes in the hippocampus and amygdala of Octodon degus: influence of maternal vocalizations. Journal of Neuroscience. 2003; Vol. 23(issue 12):5329-36. [PubMed: 12832558]

\section{References to other published versions of this review}

Anderson 2003. Anderson GC, Moore E, Hepworth J, Bergman N. Early skin-to-skin contact for mothers and their healthy newborn infants. Cochrane Database of Systematic Reviews. 2003; (Issue 2) DOI: 10.1002/14651858.CD003519.

* Indicates the major publication for the study 


\section{PLAIN LANGUAGE SUMMARY}

\section{Early skin-to-skin contact for mothers and their healthy newborn infants}

Skin-to-skin contact between a mother and her baby at birth reduces crying, and helps the mother to breastfeed successfully.

In many cultures, babies are generally cradled naked on their mother's bare chest at birth. Historically, this was necessary for the baby's survival. In recent times, in some societies such as in industrialized countries more babies are born in hospital, and as part of usual hospital care babies are often separated and swaddled or dressed before being given to their mothers. It has been suggested that hospital routines may significantly disrupt early mother and baby interactions and have harmful effects. This review was done to see if there was any impact of early skin-to-skin contact between the mother and her newborn baby on infant health, behavior, and breastfeeding.

The review included 34 randomized studies involving 2177 mothers and their babies. It showed that babies exposed to skin-to-skin contact interacted more with their mothers and cried less than babies receiving usual hospital care. Mothers were more likely to breastfeed in the first one to four months, and tended to breastfeed longer, if they had early skin-to-skin contact with their babies. Babies were possibly more likely to have a good early relationship with their mothers but this was difficult to measure. The overall methodological quality of trials was mixed. There was variation in how the intervention was implemented, including the time of skin-to-skin contact started after the birth and how long it lasted, the outcomes looked at and how they were measured. No clear negative outcomes were reported in association with skin-to-skin contact. 


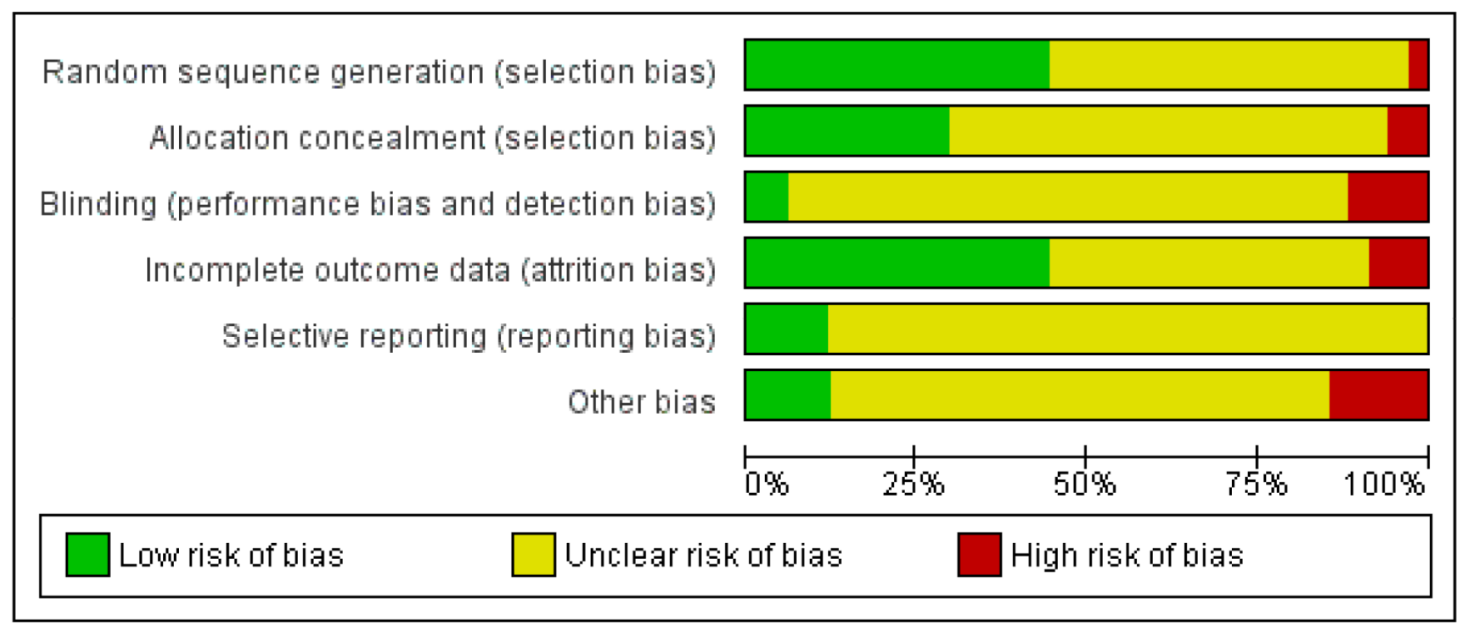

Figure 1. Risk of bias graph: review authors' judgements about each risk of bias item presented as percentages across all included studies. 


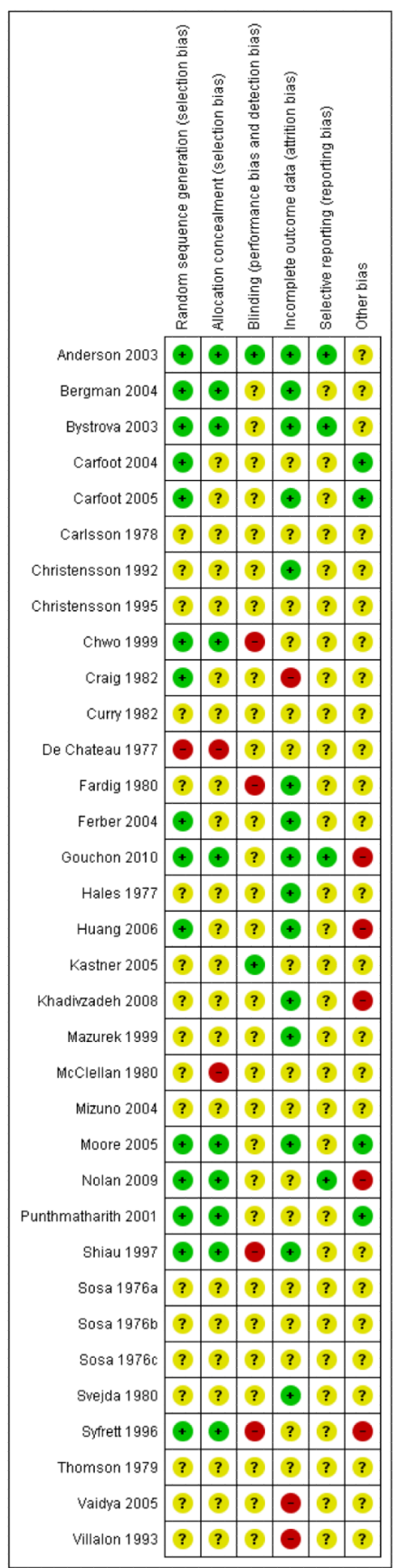

Figure 2. Risk of bias summary: review authors' judgements about each risk of bias item for each included study. 


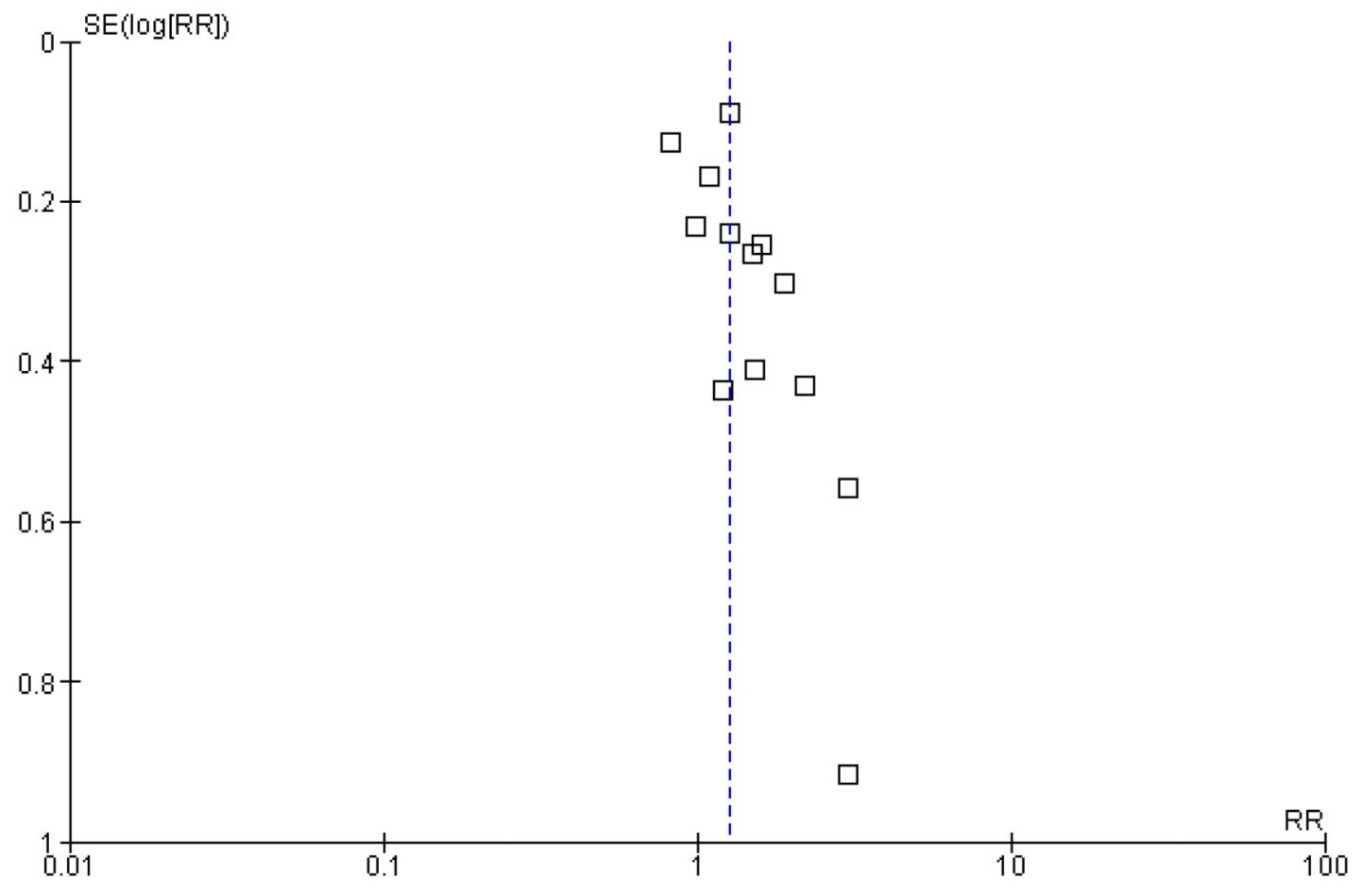

Figure 3. Funnel plot of comparison: 1 Skin-to-skin versus standard contact healthy infants, outcome: 1.1 Breastfeeding 1 month to 4 months postbirth. 